\title{
NRHP Eligibility of the Fort Huachuca, Arizona, Elevated Water Tank (Facility 49001) and Reservoir (Facility 22020)
}

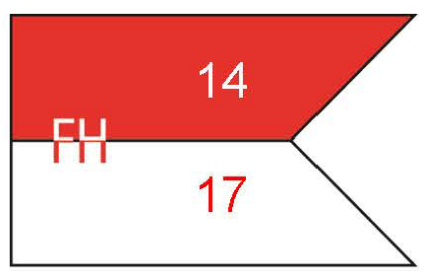

Fort Huachuca Cultural Resources Report $\mathrm{FH}-14-17$
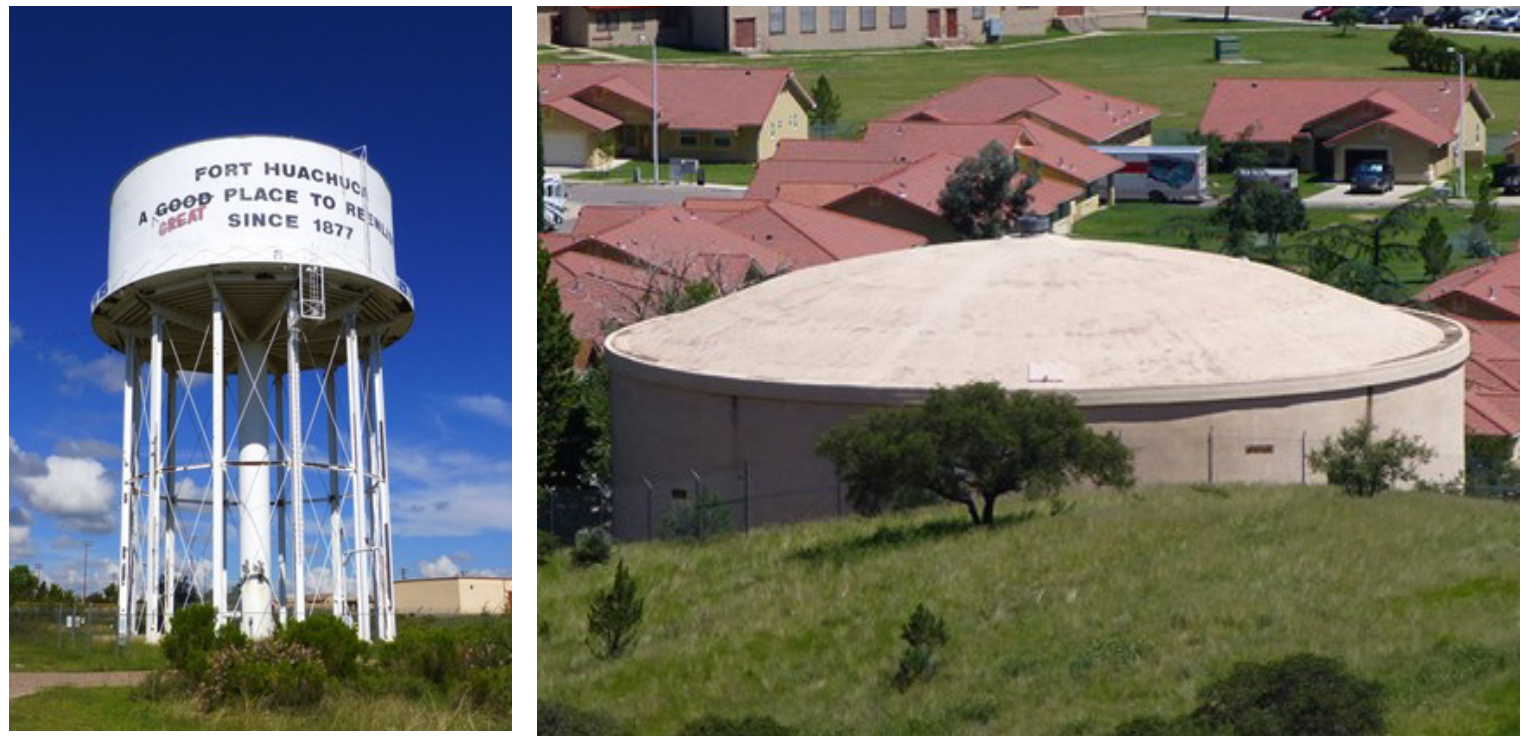
The U.S. Army Engineer Research and Development Center (ERDC) solves the nation's toughest engineering and environmental challenges. ERDC develops innovative solutions in civil and military engineering, geospatial sciences, water resources, and environmental sciences for the Army, the Department of Defense, civilian agencies, and our nation's public good. Find out more at www.erdc.usace.army.mil.

To search for other technical reports published by ERDC, visit the ERDC online library at http://acwc.sdp.sirsi.net/client/default.

Cover Photo: Elevated water tank (Facility 49001) looking northwest (left), and reservoir (Facility 22020) looking east (right) (ERDC-CERL, 2014). 


\section{NRHP Eligibility of the Fort Huachuca, Arizona, Elevated Water Tank (Facility 49001) and Reservoir (Facility 22020)}

Adam D. Smith and Courtney F. Wesa

Construction Engineering Research Laboratory

US Army Engineer Research and Development Center

2902 Newmark Drive

PO Box 9005

Champaign, IL 61826-9005

Final Report

Approved for public release; distribution is unlimited.

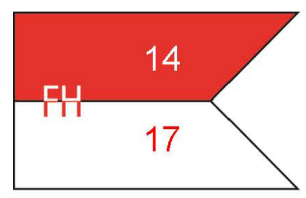

Fort Huachuca Cultural Resources Report FH-14-17

Prepared for Environmental and Natural Resources Division

Directorate of Public Works

U.S. Army Garrison

3040 Butler Road, Building 22526

Fort Huachuca, AZ 85613

Under Project No. 447607, "Determination of Eligibility of a World War II Water

Tower at Fort Huachuca." 


\section{Abstract}

This document is an assessment of National Register of Historic Places (NRHP) eligibility of the Fort Huachuca, Arizona, elevated water tank (Facility 49001) erected in 1941 and a reservoir (Facility 22020) constructed in 1959. The elevated water tank (Facility 4901) has remained generally unchanged except for different painting schemes. The demolition and reconstruction of the surrounding World War II temporary buildings makes this portion of the Fort Huachuca cantonment ineligible for the NRHP as a historic district. Although unchanged since its construction, the reservoir (Facility 22020) is not significant for construction technology. This survey satisfies Section 110 of the National Historic Preservation Act of 1966 as amended, and was used to determine the eligibility of the elevated water tank under Section 106 of the NHPA due to an undertaking, and the eligibility of the reservoir under Section 110 of the NHPA for inclusion on the NRHP.

It is the recommendation of this report that the elevated water tank (Facility 49001) is not eligible to the NRHP since it is not individually significant and is not part of a larger historic district. The reservoir (Facility 22020) is individually not significant, and it is not part of a larger historic district.

DISCLAIMER: The contents of this report are not to be used for advertising, publication, or promotional purposes. Citation of trade names does not constitute an official endorsement or approval of the use of such commercial products. All product names and trademarks cited are the property of their respective owners. The findings of this report are not to be construed as an official Department of the Army position unless so designated by other authorized documents. 


\section{Contents}

Abstract................. if

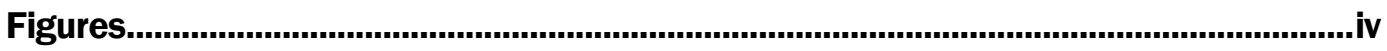

Preface ............................................................................................................................vi

Unit Conversion Factors..................................................................................................vii

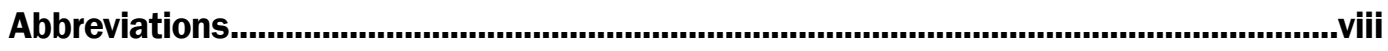

1 Introduction ..................................................................................................... 1

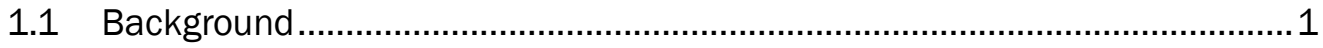

1.2 Objective.......................................................................................... 2

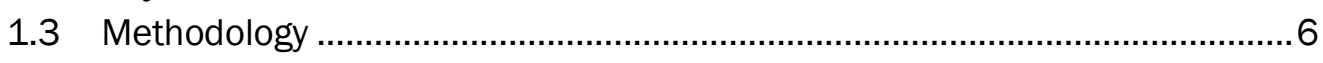

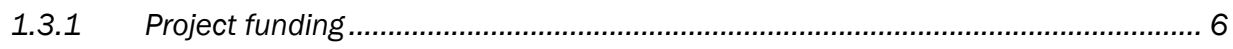

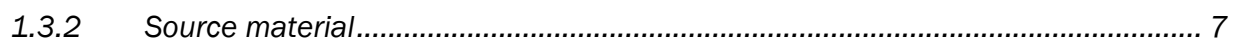

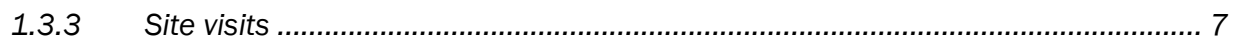

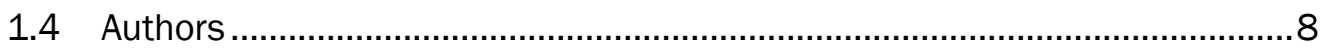

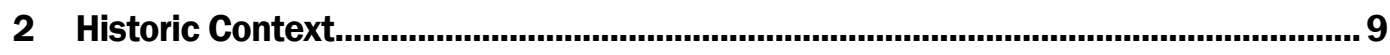

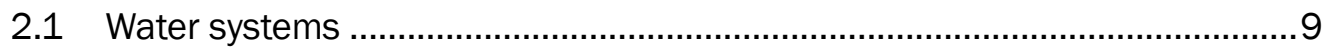

2.2 Elevated water tanks .............................................................................. 10

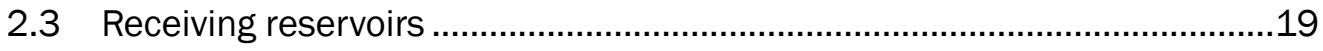

2.4 The water system at Fort Huachuca ........................................................21

3 Inventory Results and Conclusion (Determination of Eligibility).............................33

3.1 Categories of historic properties ............................................................ 33

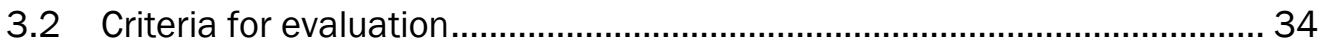

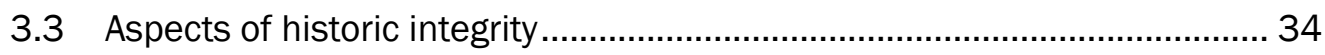

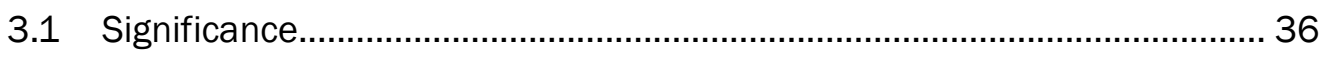

3.1.1 National, state, or local significance.......................................................... 36

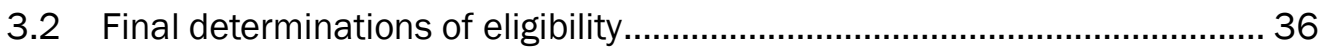

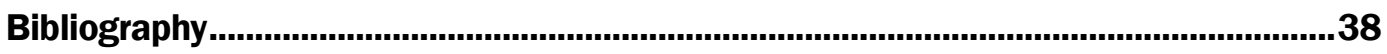

Appendix: Fort Huachuca Historic Property Inventory Forms ....................................40

Report Documentation Page 


\section{Figures}

Figure 1. Fort Huachuca Historic District boundary (Wee and Mikesell 1993). ................... 3

Figure 2. Map with location of Fort Huachuca, Arizona (Google Maps, www.google.com, accessed January 2016).

Figure 3. Map of Fort Huachuca, with location of elevated water tank (Facility 49001) and reservoir (Facility 22020) marked by heavy outline (Vanderpot 2012,

3).

Figure 4. Area surrounding the elevated water tank (Facility 49001) (Fort Huachuca DPW). 5

Figure 5. Area surrounding the reservoir (Facility 22020) (Fort Huachuca DPW).

Figure 6. Standpipe at Naval Support Facility Indian Head, Maryland, on left versus an elevated water tank on right at Fort Gordon, Georgia (ERDC-CERL 2008 [left] and 2004 [right]).

Figure 7. Wooden tank design in Beaumont, Kansas (J. Stephen Conn on

flickr.com).

Figure 8. Circular steel tank with bolted joints (ERDC-CERL, 2006).

Figure 9. Double-ellipsoidal water tower at Youngstown Air Reserve Station, Ohio (ERDC-CERL 2010).

Figure 10. Torospherical water tower in Mount Prospect, Illinois (Derek Graham on flickr.com).

Figure 11. Pedestal water tower in Milford, Delaware (Mike Mahaffie on flickr.com).

Figure 12. Hydropillar water tower in Tulsa, Oklahoma (Topato on flickr.com).

Figure 13. Madison Barracks, New York, water tower (ERDC-CERL, 2007).

Figure 14. Fort Sheridan, Illinois, water tower (ERDC-CERL, 2010).

Figure 15. Collinsville, Illinois, bottle-shaped water tower (ERDC-CERL, 2010).

Figure 16. View of Los Angeles' Silver Lake Reservoir in 1973 (Los Angeles Public Library image 46330).

Figure 17. View of New York's Croton Reservoir in 1899 (New York Public Library)...........21

Figure 18. The Old Post Reservoir dates to 1884 and is shown in this photo from 1900 (Herbert 1990, 57).

Figure 19. 1941 water supply (Herbert 1990, 121).

Figure 20. Location of Fort Huachuca Wells \#1 and \#2 at the east gate, 1943 (NARA Riverside RG77-Folder 2).

Figure 21. Head of turbine pump for Well \#2 installed on concrete foundation with workmen starting wall forms for the pump house, 1939 (NARA College Park RG77-133).

Figure 22. Well house for Well \#2 under construction in 1941 (NARA College Park RG77-133).

Figure 23 Layout of Fort Huachuca in 1945, showing the original cantonment on the left and the new cantonment on the right [boxes mark the location of two elevated water tanks (Fort Huachuca DPW). 
Figure 24. Location of the five wells on the east boundary (NARA Riverside RG77-Folder 2)

Figure 25. Aerial of Fort Huachuca, looking east with the twin elevated water tanks visible in center [marked by red boxes], 1945 (Fort Huachuca Museum Collection). .28

Figure 26. View of the elevated water tank (Facility 49001), 1 May 1941 (NARA College Park RG77-133).

Figure 27. Aerial of Fort Huachuca, looking north with the elevated water tank erected in 1941 on the top left and the elevated water tank erected in 1942 on the far right [marked by boxes], 1954. (NARA 111-SCA).

Figure 28. Concrete 1,500,000 gallon reservoir (Facility 22020), constructed in 1959, is shown near bottom right corner in this 1960 photo (Fort Huachuca Museum Collection).

Figure 29. Deconstruction of the 1942 elevated water tank (Facility 70411) in 1974 (Fort Huachuca Museum Collection). 


\section{Preface}

This study was conducted for the Environmental and Natural Resources Division (ENRD) in the Directorate of Public Works at Fort Huachuca, Arizona, under Project No. 447607, "Determination of Eligibility of a World War II Water Tower at Fort Huachuca." The technical monitor was Mr. Martyn Tagg, Cultural Resources Manager.

The work was performed by the Land and Heritage Conservation Branch (CNC) of the Installations Division (CN), U.S. Army Engineer Research and Development Center - Construction Engineering Research Laboratory (ERDC-CERL). At the time of publication, Dr. Michael Hargrave was Chief, CEERD-CNC; and Ms. Michelle Hanson was Chief, CEERD-CN. The Deputy Director of ERDC-CERL was Dr. Kirankumar Topudurti, and the Director was Dr. Ilker Adiguzel.

COL Bryan S. Green was the Commander of ERDC, and Dr. Jeffery P. Holland was the Director. 
ERDC/CERL TR-16-12

vii

Unit Conversion Factors

\begin{tabular}{|l|l|l|}
\hline Multiply & By & To Obtain \\
\hline acres & \multicolumn{1}{|c|}{$4,046.873$} & square meters \\
\hline feet & 0.3048 & meters \\
\hline inches & 0.0254 & meters \\
\hline miles (U.S. statute) & $1,609.347$ & meters \\
\hline square feet & 0.09290304 & square meters \\
\hline yards & 0.9144 & meters \\
\hline
\end{tabular}




\section{Abbreviations}

$\begin{array}{ll}\text { Term } & \text { Meaning } \\ \text { DPW } & \text { Directorate of Public Works } \\ \text { ENRD } & \text { Environmental and Natural Resources Division } \\ \text { EPG } & \text { Electronic Proving Ground } \\ \text { ERDC- } & \text { Engineer Research and Development Center - Construction } \\ \text { CERL } & \text { Engineering Research Laboratory } \\ \text { JITC } & \text { Joint Interoperability Test Command } \\ \text { MARS } & \text { Military Affiliate Radio System } \\ \text { MIPR } & \text { Military Interdepartmental Purchase Request } \\ \text { NARA } & \text { National Archives and Records Administration } \\ \text { NETCOM } & \text { Network Enterprise Technology Command } \\ \text { NHPA } & \text { National Historic Preservation Act } \\ \text { NRHP } & \text { National Register of Historic Places } \\ \text { SRM } & \text { sustainment, restoration, and modernization } \\ \text { USGS } & \text { U.S. Geological Survey } \\ \text { WPA } & \text { Works Progress Administration } \\ \text { WWII } & \text { World War II }\end{array}$




\section{Introduction}

Fort Huachuca is located on the eastern slope of the Huachuca Mountains that are north and west of Sierra Vista, Arizona. The heart of the cantonment for the fort is its National Historic Landmark historic district, Fort Huachuca Historic District, nestled in a valley overlooking the San Pedro River valley (Figure 1).

The Army established Camp Huachuca in 1877; it did not become a permanent Army post until 1882. Most of the buildings within the Old Post area date from the late 1880 . The post grew again in the 1910 s, prior to World War I. From 1913 to 1931, the Tenth Cavalry was stationed at Fort Huachuca and was comprised of white officers and black troops. ${ }^{1}$ The Army changed the post from a cavalry orientation to infantry in 1931, and it was the home of the $93^{\text {rd }}$ and $92^{\text {nd }}$ Infantry Divisions from 1942 to 1945.

In 1947, the post was closed and used by the Arizona Game and Fish Department until January 1951, when it reopened for the Korean Conflict. The post closed again at the end of the conflict, but reopened in February 1954 as the U.S. Army Electronic Proving Ground. It is currently headquarters for U.S. Army Intelligence Center of Excellence, which is the senior mission on post, and the U.S. Army Network Enterprise Technology Command (NETCOM)/9th Army Signal Command. Fort Huachuca is also the headquarters of the Army's Military Affiliate Radio System (MARS), the Joint Interoperability Test Command (JITC), and the Electronic Proving Ground (EPG).

\subsection{Background}

Congress codified the National Historic Preservation Act of 1966 (NHPA), the nation's most effective cultural resources legislation to date, in order to provide guidelines and requirements for preserving tangible elements of our past. This was done primarily through the creation of the National Register of Historic Places (NRHP) in 1966. Contained within the NHPA (Sections 106 and 110) are requirements for federal agencies to address their cultural resources, which are defined as any prehistoric or historic

\footnotetext{
1 Paul Chattey, Historic Context: The Army's Military Mission at Fort Huachuca, Arizona 1877-1940, (Seattle, WA: Center for Expertise for Preservation of Structures and Buildings, USACE, 2000), 14.
} 
district, site, building, structure, or object. Section 110 requires federal agencies to inventory and evaluate their cultural resources. Section 106 requires determination of the effects of federal undertakings on properties deemed eligible or potentially eligible for the NRHP.

\subsection{Objective}

This study was executed for the Environmental and Natural Resources Division (ENRD) in the Directorate of Public Works (DPW) at Fort Huachuca, Arizona (Figure 2 and Figure 3) to assess the historical significance and eligibility to the NRHP of: (1) the elevated water tank (Facility 49001), erected in 1941 near the intersection of Cushing Street and North Railroad Avenue (Figure 4), and (2) the reservoir (Facility 22020), located on a hillside above the end of Boyd Avenue (Figure 5). For a property to qualify for the NRHP, it must meet at least one of the National Register Criteria for Evaluation, must be significantly associated with an important historic context, and must retain sufficient integrity to convey its significance.

This survey was initiated under Section 106 of the NHPA due to a proposed undertaking to paint and upgrade the safety features on the elevated water tank (Facility 49001). The water reservoir (Facility 22020) was added to this project and was surveyed under Section 110 of the NHPA. This survey satisfies both Section 106 and Section 110 of the NHPA of 1966 (as amended), and was used to recommend the eligibility of the elevated water tank and the reservoir for inclusion on the NRHP. 
Figure 1. Fort Huachuca Historic District boundary (Wee and Mikesell 1993).

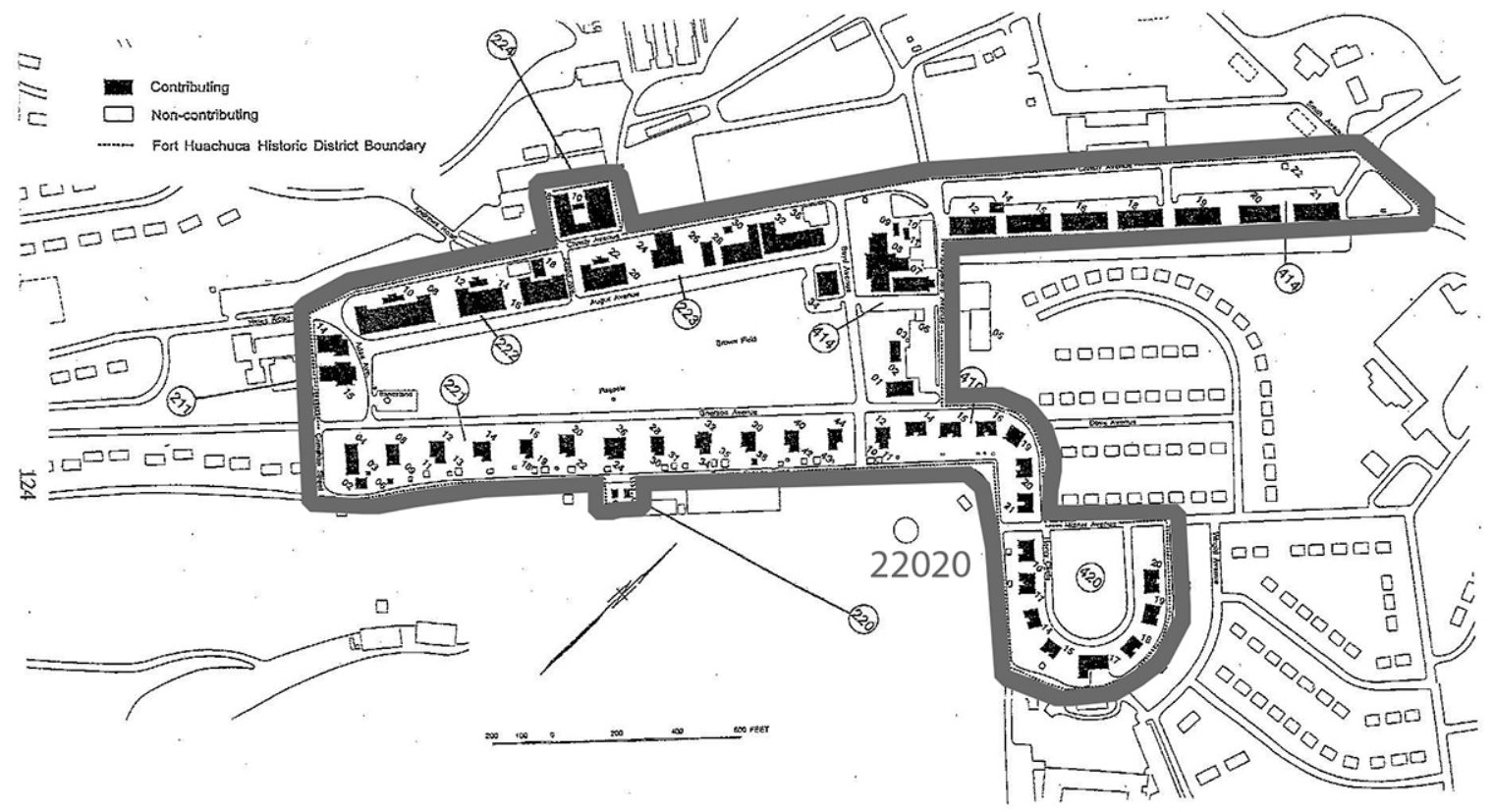

Figure 2. Map with location of Fort Huachuca, Arizona (Google Maps, www.google.com, accessed January 2016).

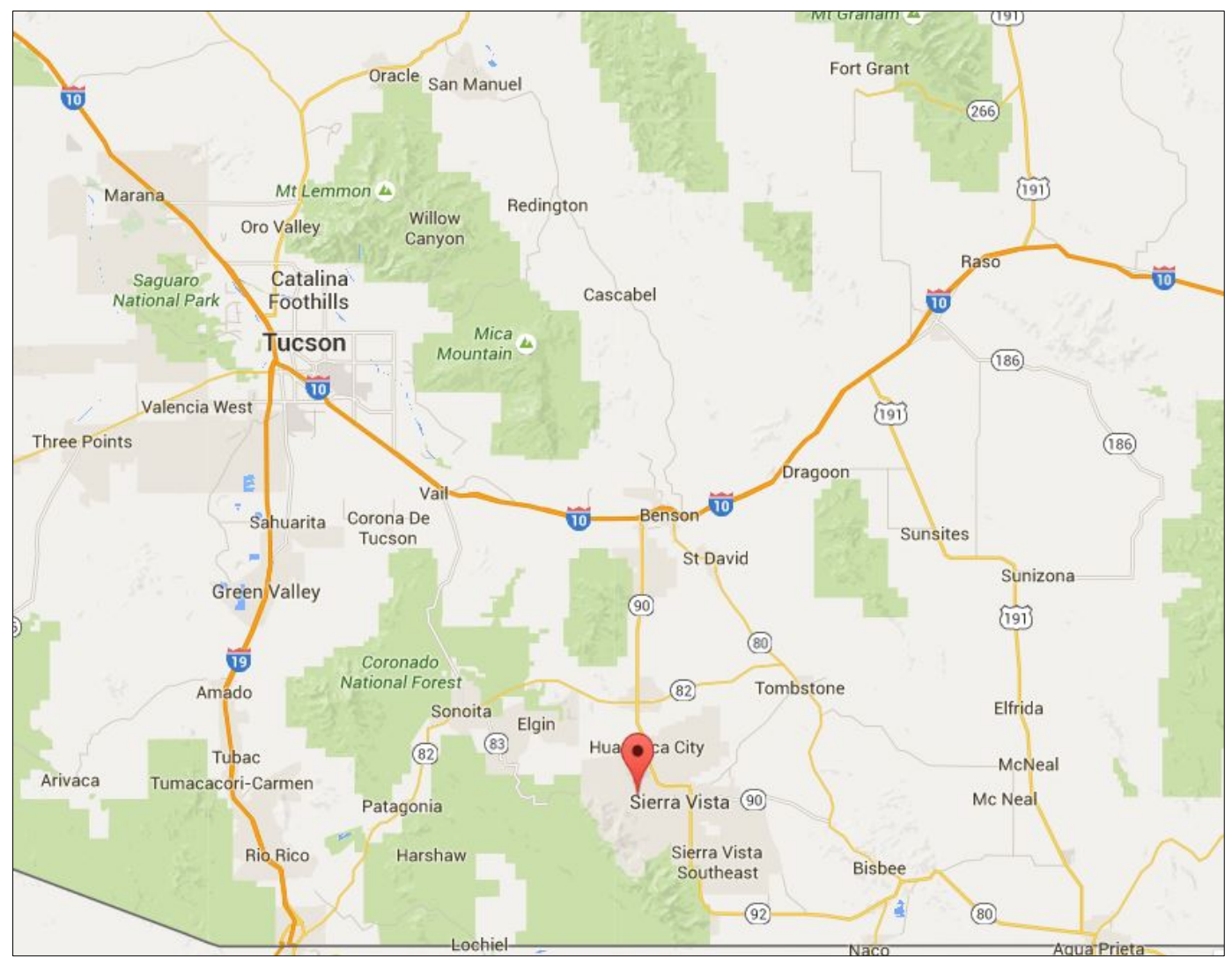


Figure 3. Map of Fort Huachuca, with location of elevated water tank (Facility 49001) and reservoir (Facility 22020) marked by heavy outline (Vanderpot 2012, 3).

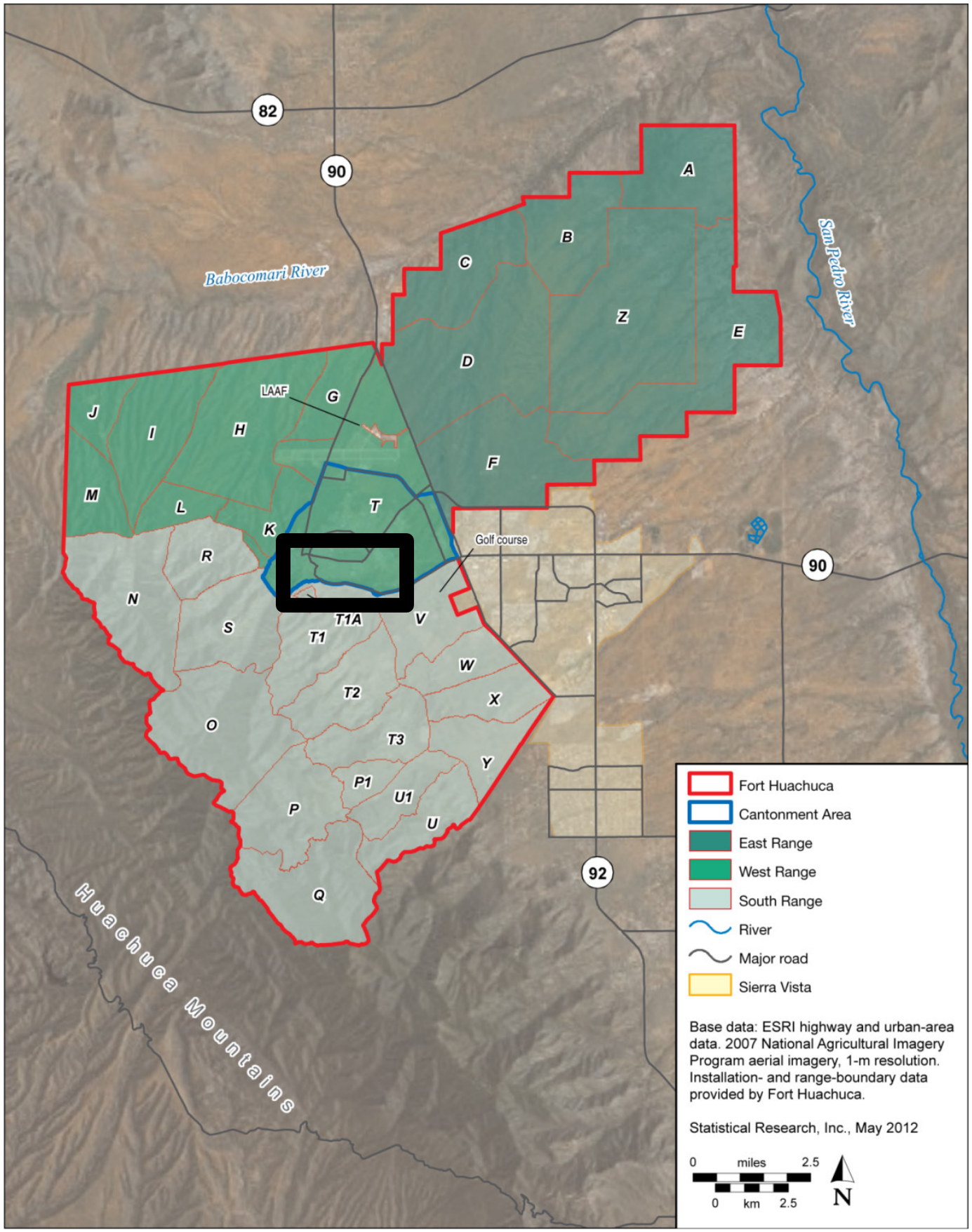


Figure 4. Area surrounding the elevated water tank (Facility 49001)

(Fort Huachuca DPW).

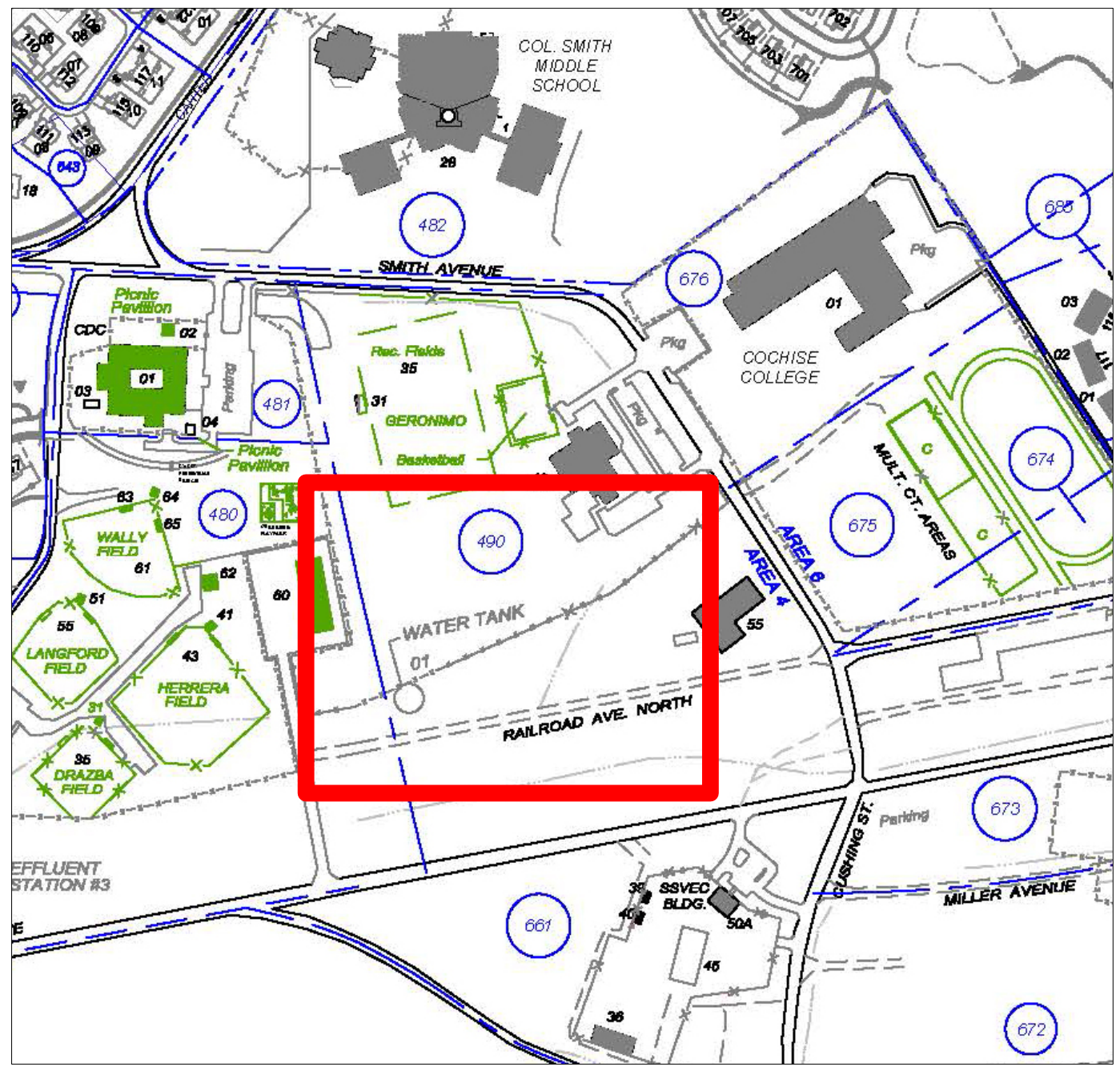


Figure 5. Area surrounding the reservoir (Facility 22020) (Fort Huachuca DPW).

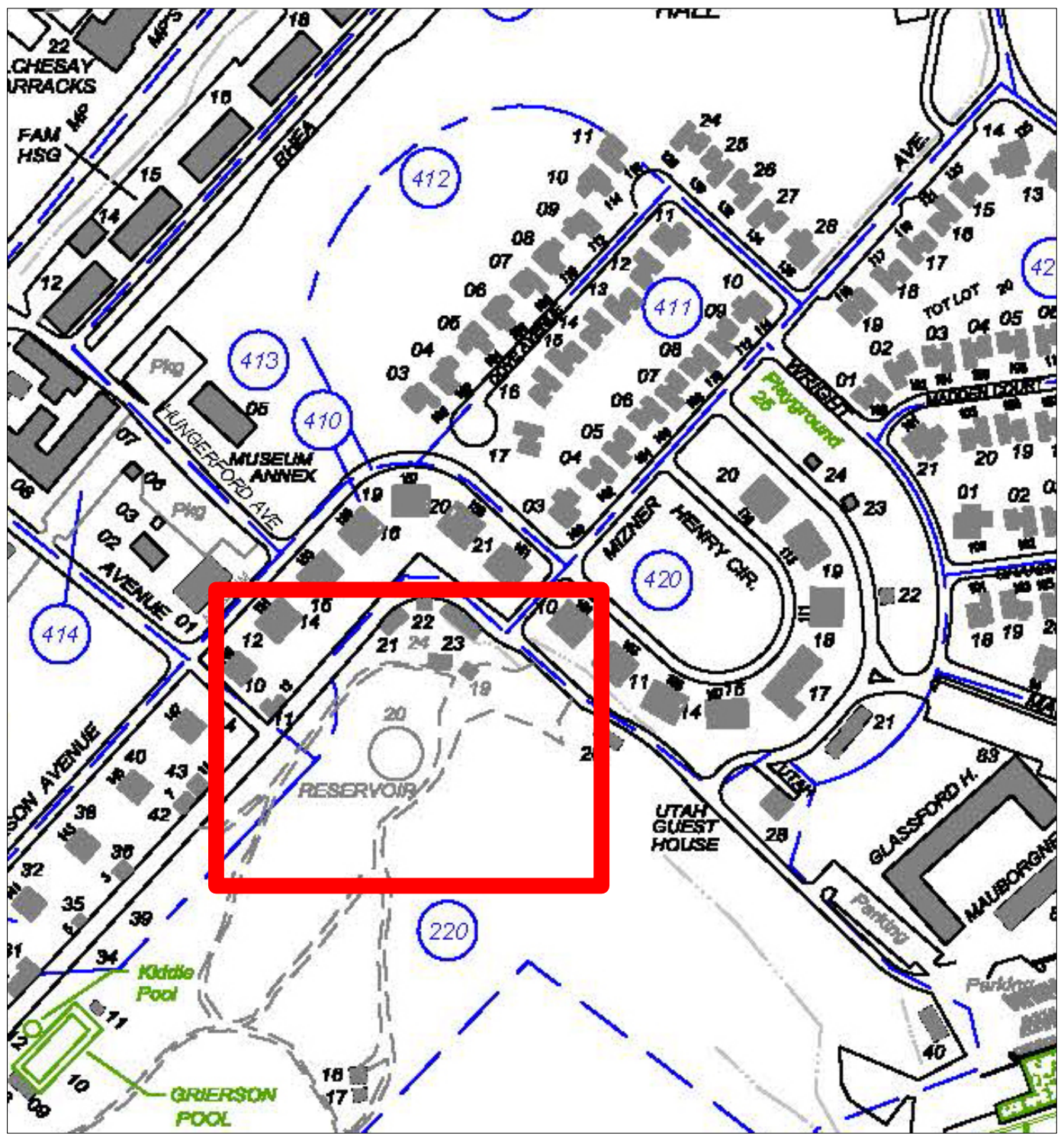

\subsection{Methodology}

\subsubsection{Project funding}

Under a Military Interdepartmental Purchase Request (MIPR), the Engineer Research and Development Center-Construction Engineering Research Laboratory (ERDC-CERL) was retained by the Fort Huachuca DPW (ENRD Cultural Resources) to complete an evaluation of eligibility to the NRHP for the elevated water tank (Facility 49001) located at Fort Huachuca, Arizona. While at the site visit in August 2014, it was decided to include the reservoir (Facility 22020) in the evaluation. 


\subsubsection{Source material}

ERDC-CERL researchers conducted a review of books, archival repositories, and online resources related to Fort Huachuca and its water system. The following places were contacted and/or searched:

- ENRD Cultural Resources Office at Fort Huachuca

- Fort Huachuca, Arizona: A Century of Development and Changing Missions 1877-1977, August 1990

- FY12 SRM (Sustainment, Restoration and Modernization) Facilities and Demolition Projects: Documentation and National Register Evaluation of 29 Buildings on Fort Huachuca, Arizona, 2011

- Architectural Survey, Documentation, and Evaluation of 110 Buildings and Structures at Fort Huachuca, Arizona, June 2013

- Inventory, Documentation, and Evaluation of 30 Buildings and Structures, 194 Works Progress Administration (WPA) Features, and Identification of a Potential WPA Historic District at Fort Huachuca, Arizona, March 2014

- National Archives and Records Administration (NARA) at College Park, Maryland

- RG77 Records of the Corps of Engineers

- RG111-SC Records of the Chief Signal Officer

- RG111-SCA Records of the Chief Signal Officer

- National Archives at Riverside, California

- RG77 Records of the Chief of Engineers, Los Angeles District

- University of Illinois at Urbana-Champaign Library at Urbana, Illinois

- ERDC Library

- Fort Huachuca Museum Collection

- Fort Huachuca DPW

- Fort Huachuca Real Property Office

- www.flickr.com

- U.S. Geological Survey (USGS)

\subsubsection{Site visits}

A researcher conducted one site visit to Fort Huachuca, Arizona, to tour the elevated water tank (Facility 49001) facility in August 2014. As part of this visit, archival repositories in the area were investigated, including the Fort Huachuca DPW office, the real property office, and the museum. During a tour of the water facilities, it was decided to include the reservoir (Facility 22020), constructed in 1959, which also had not been evaluated 
for NRHP eligibility. One researcher also visited the National Archives at College Park in September 2014 to research the construction of the elevated water tank.

\subsection{Authors}

This project was conducted by ERDC-CERL in Champaign, Illinois. The researchers were Adam Smith (M.Arch), with 18 years of experience in military architectural history, and Courtney Wesa (intern). 


\section{Historic Context}

This chapter contributes to the evaluation of the significance of the 500,000 gallon elevated water tank (Facility 49001) erected in 1941 and the 1,500,000 gallon concrete reservoir (Facility 22020) constructed in 1959 at Fort Huachuca, Arizona, by situating them within the general historic context of water tower design and construction.

\subsection{Water systems}

Water distribution has always been important in human civilization. Most notable are the precisely engineered Roman aqueducts that-to this daytransfer water over long distances. Aqueducts use gravity to convey water from higher to lower elevations, and regional topography determined water system design and location. Often, these systems included networks of fountains and retention basins. ${ }^{2}$ While water systems materials and designs have changed, the basic gravity-fed concept used by the Romans remains the same.

The oldest water system in the United States dates from 1754, when Hans Christopher Christiansen erected a 225,000-gallon standpipe in Bethlehem, Pennsylvania.3 Standpipes are supported directly on the ground, and the pressure needed for the water system determines the height of the structure (Figure 6). Most municipalities in the United States use gravity-fed water systems that use water tanks to provide adequate pressure for the system.

2 J.N. Hazlehurst, Towers and Tanks for Water-Works (New York: John Wiley \& Sons, 1904), 1.

3 ibid., 5. 
Figure 6. Standpipe at Naval Support Facility Indian Head, Maryland, on left versus an elevated water tank on right at Fort Gordon, Georgia

(ERDC-CERL 2008 [left] and 2004 [right]).

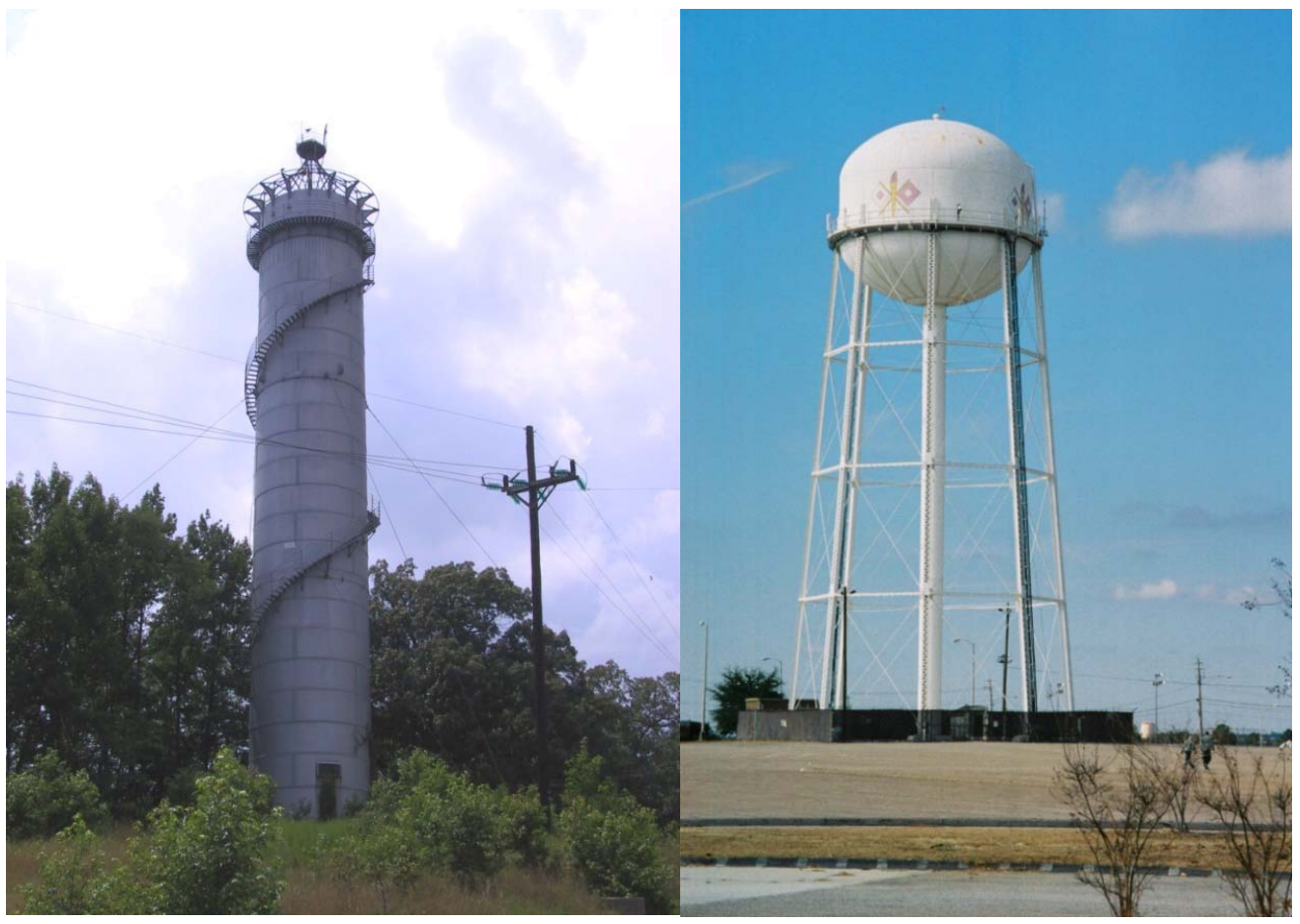

\subsection{Elevated water tanks}

The current primary purpose of water tanks is to store water and pressurize water systems, although historically, tanks were used for other purposes. With the advent of railroads, water tanks were built near rail lines to replenish the water needed for steam locomotives. In urban areas, water tanks provide needed reservoirs for firefighting (Gray 1947, 1) and give needed pressure and storage for high-rise buildings.

In the United States, elevated water tank design adopted four basic types of construction. Effective water tanks require two structural elements. The first is the water reservoir and the second is a structure that elevates the reservoir to the required elevation to pressurize the system. Elevated water tanks can be constructed out of wood planks held in place with wroughtiron tie rods (Figure 7). Another type is the circular tank using steel plates welded together to cover the full depth of the tank (Figure 8). A third type 
is the iron cylindrical tank with tension hoops. The fourth type is the circular reinforced concrete tank. 4

Figure 7. Wooden tank design in Beaumont, Kansas (J. Stephen Conn on flickr.com).

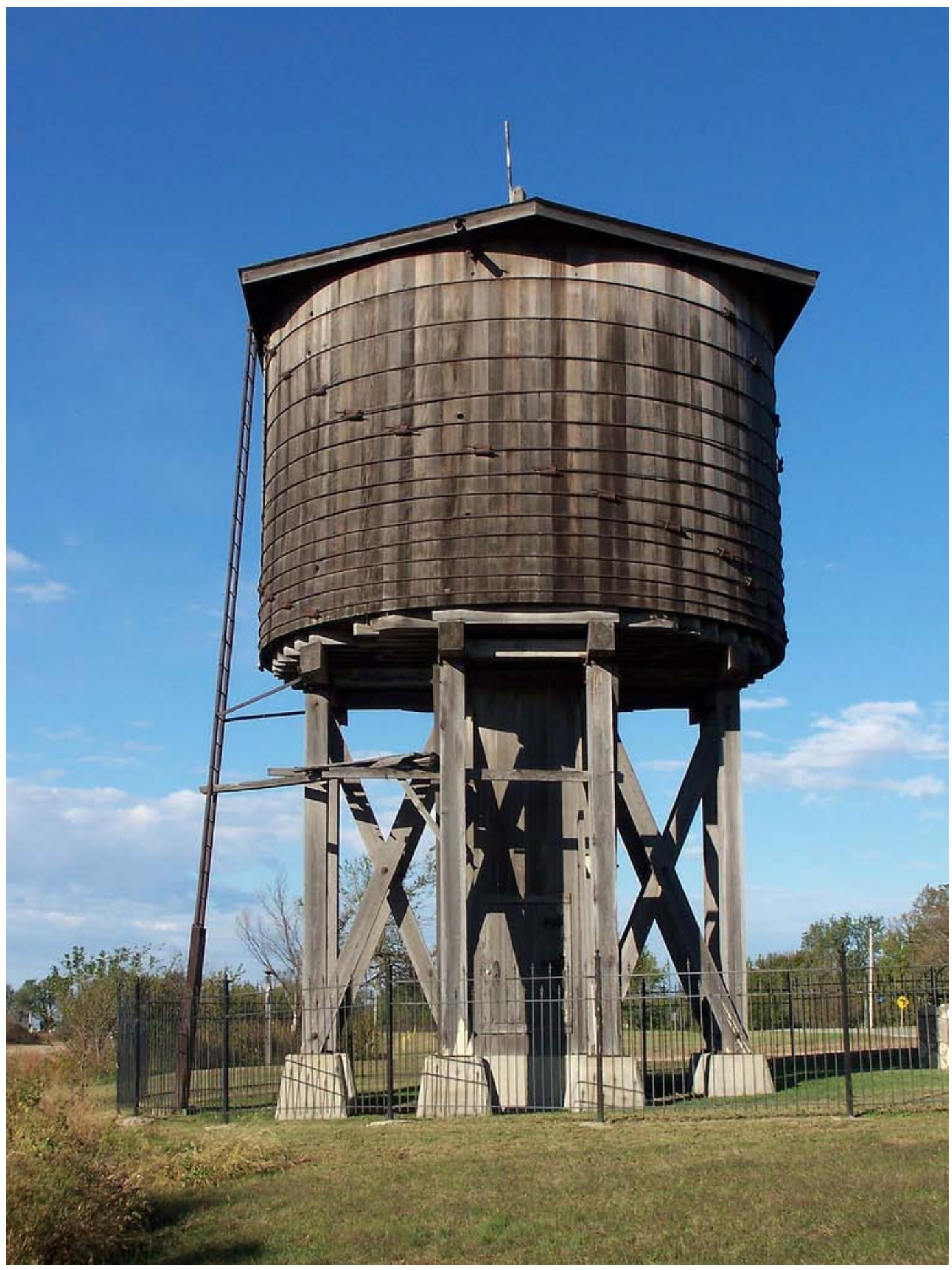

4 W.S. Gray, Reinforced Concrete Water Towers, Bunkers, Silos, and Gantries (London: Concrete Publications Limited, 1947), 1. 
Figure 8. Circular steel tank with bolted joints (ERDC-CERL, 2006).

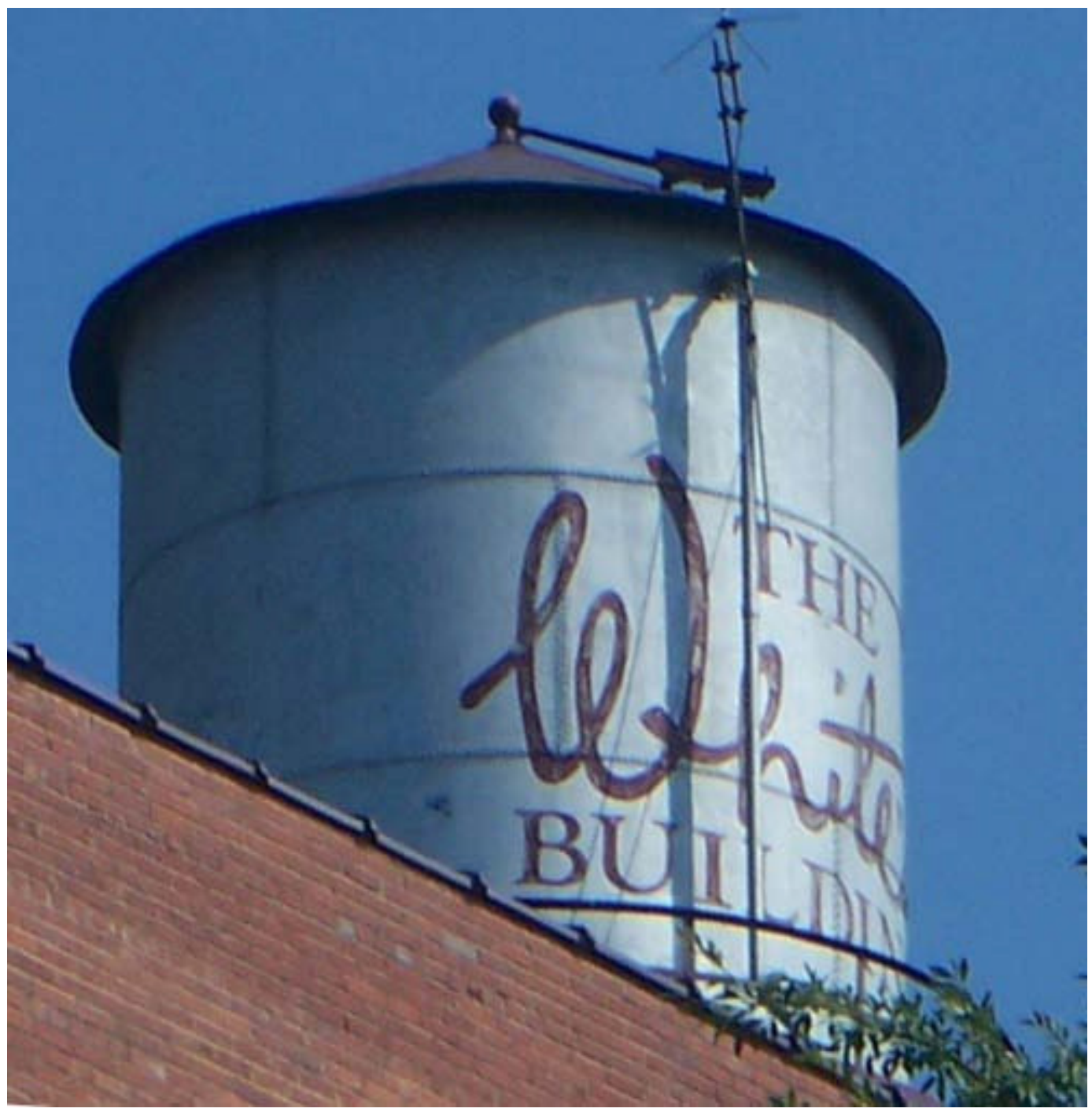

Two water tower construction companies predominated from 1946 through 1980. Together, the Chicago Bridge and Iron Company and the Pittsburgh-Des Moines Steel Company employed around 1,000 workers and erected between 8,000 and 11,000 water towers between the Mississippi River and the Rocky Mountains. 5

In the 1950s, water tank design evolved with improvements in design, materials, and construction techniques using double-ellipsoidal (Figure 9) and torospherical designs (Figure 10). ${ }^{6}$ Later in the 1960s, the pedestal

\footnotetext{
5 Ronald E. Spreng, “They Didn't Just Grow There-Building Water Towers in the Postwar Era," Minnesota History, Winter 1992, 130-141.

6 ibid., 136.
} 
(Figure 11) and the hydropillar designs (Figure 12) became popular; these designs are still being built.

Figure 9. Double-ellipsoidal water tower at Youngstown Air Reserve Station, Ohio (ERDC-CERL 2010).

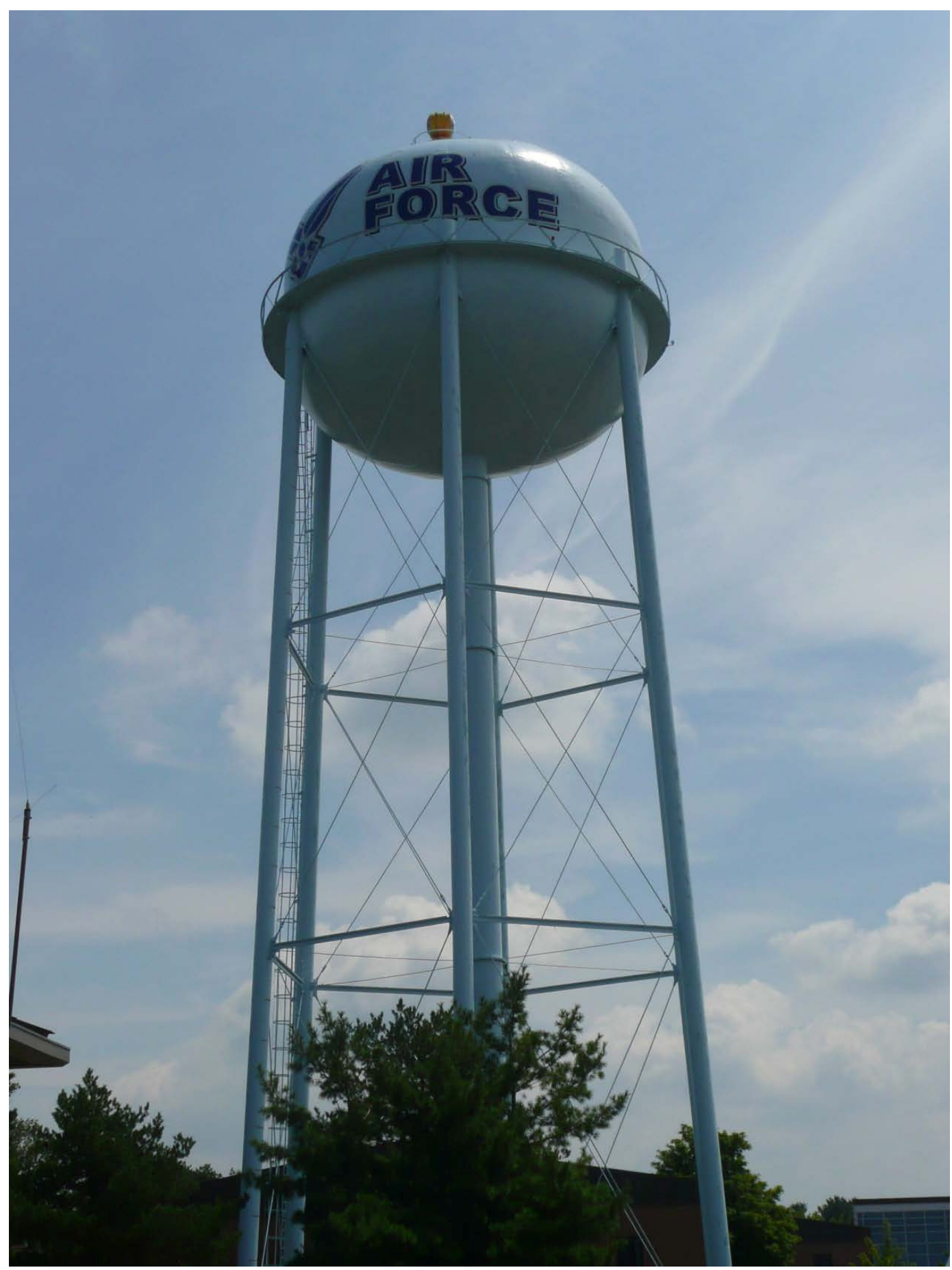


Figure 10. Torospherical water tower in Mount Prospect, Illinois (Derek Graham on flickr.com).

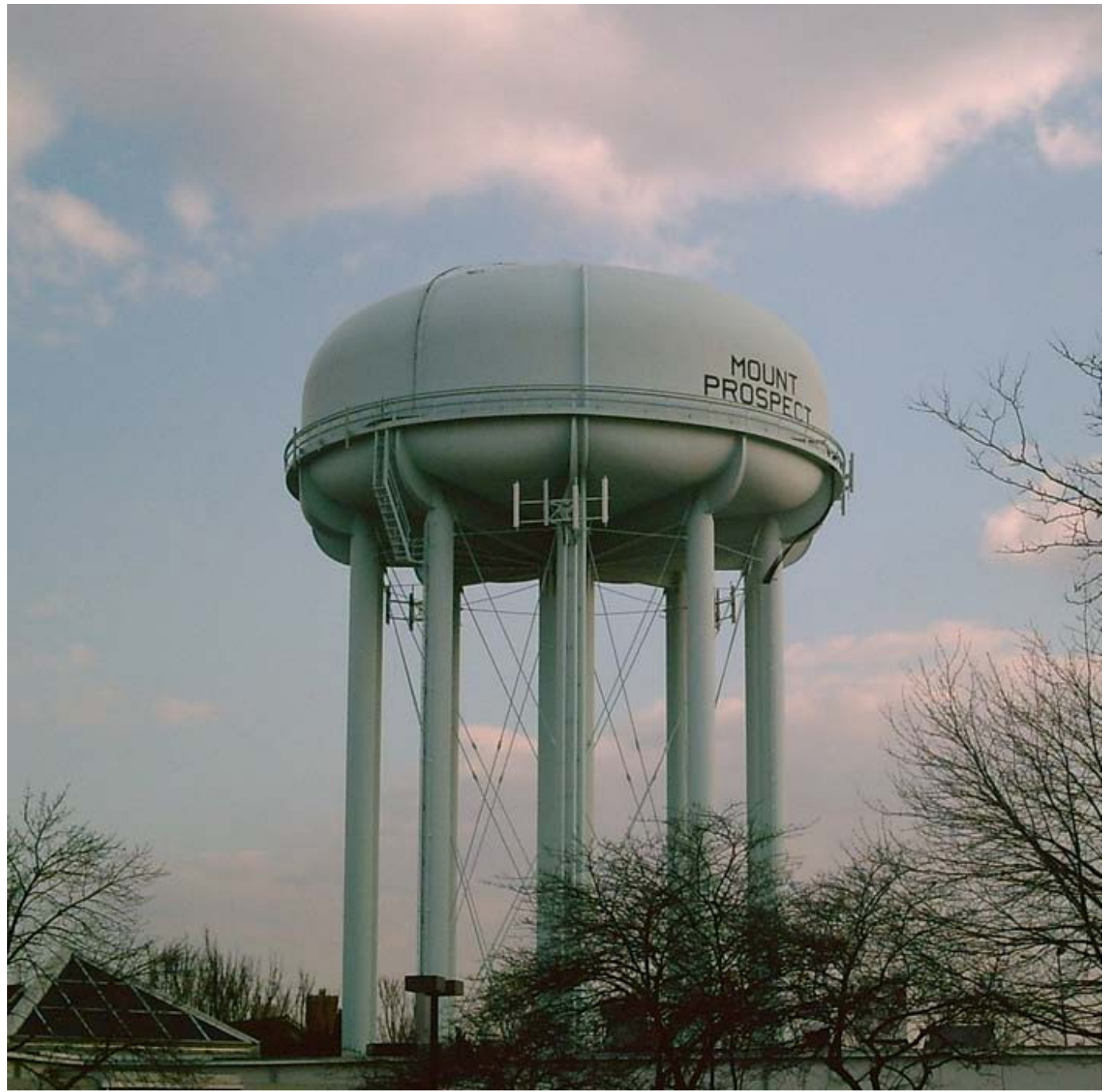


Figure 11. Pedestal water tower in Milford, Delaware (Mike Mahaffie on flickr.com).

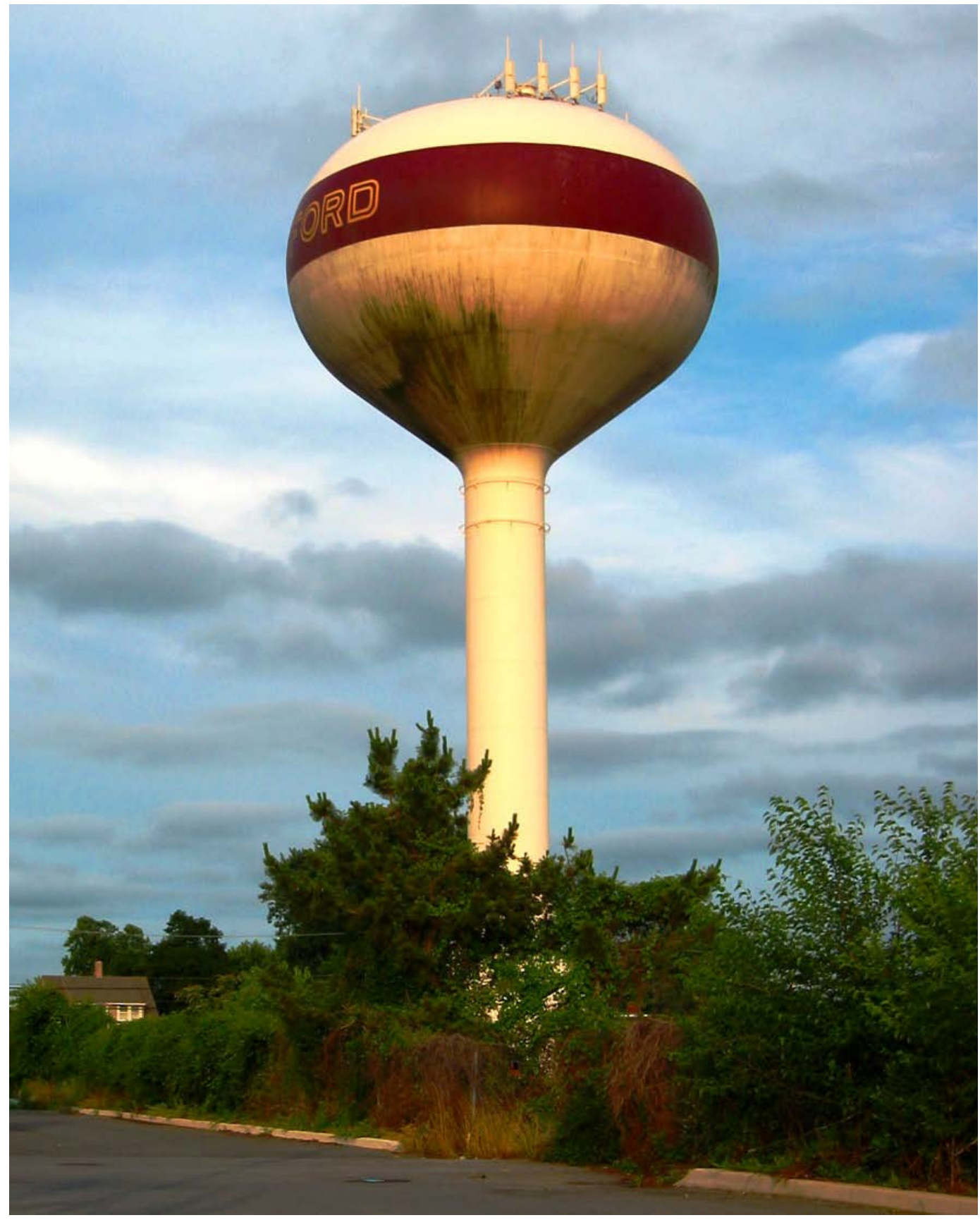


Figure 12. Hydropillar water tower in Tulsa, Oklahoma (Topato on flickr.com).

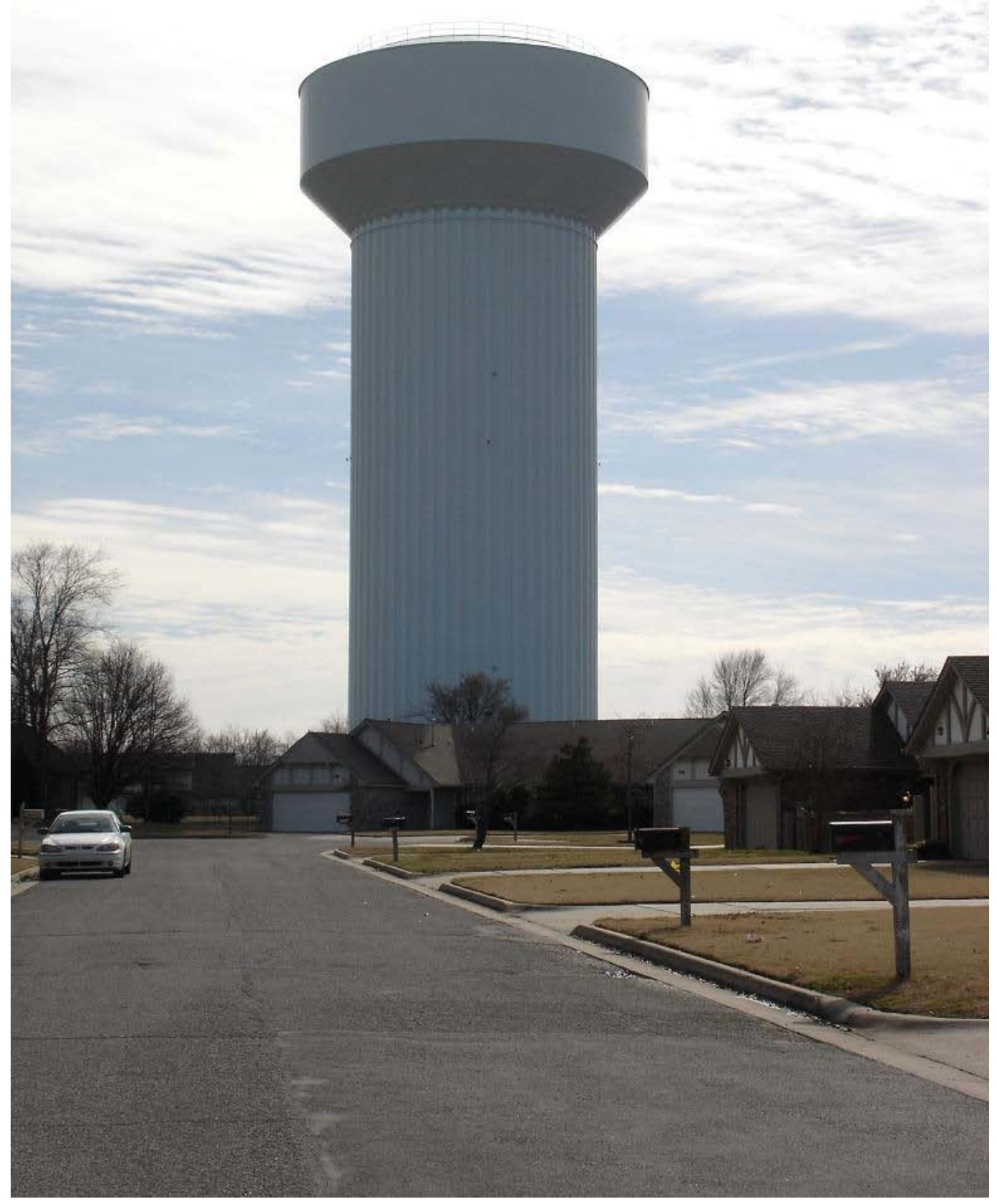

Many water towers are also architectural expressions that do not resemble a standard water tower design. Some military installations used stone water towers (e.g., the standalone tower at Madison Barracks, New York; Figure 13) and the tower at Fort Sheridan, Illinois, which also is a unifying element to the entire main barracks district (Figure 14). Some unique 
water tower designs serve a secondary advertising purpose (e.g., the water tower at the G. S. Suppiger catsup bottling plant in Collinsville, Illinois, Figure 15). No matter what their design, water towers remain the primary means of collecting and distributing most municipal water supplies. ${ }^{7}$

Figure 13. Madison Barracks, New York, water tower (ERDC-CERL, 2007).

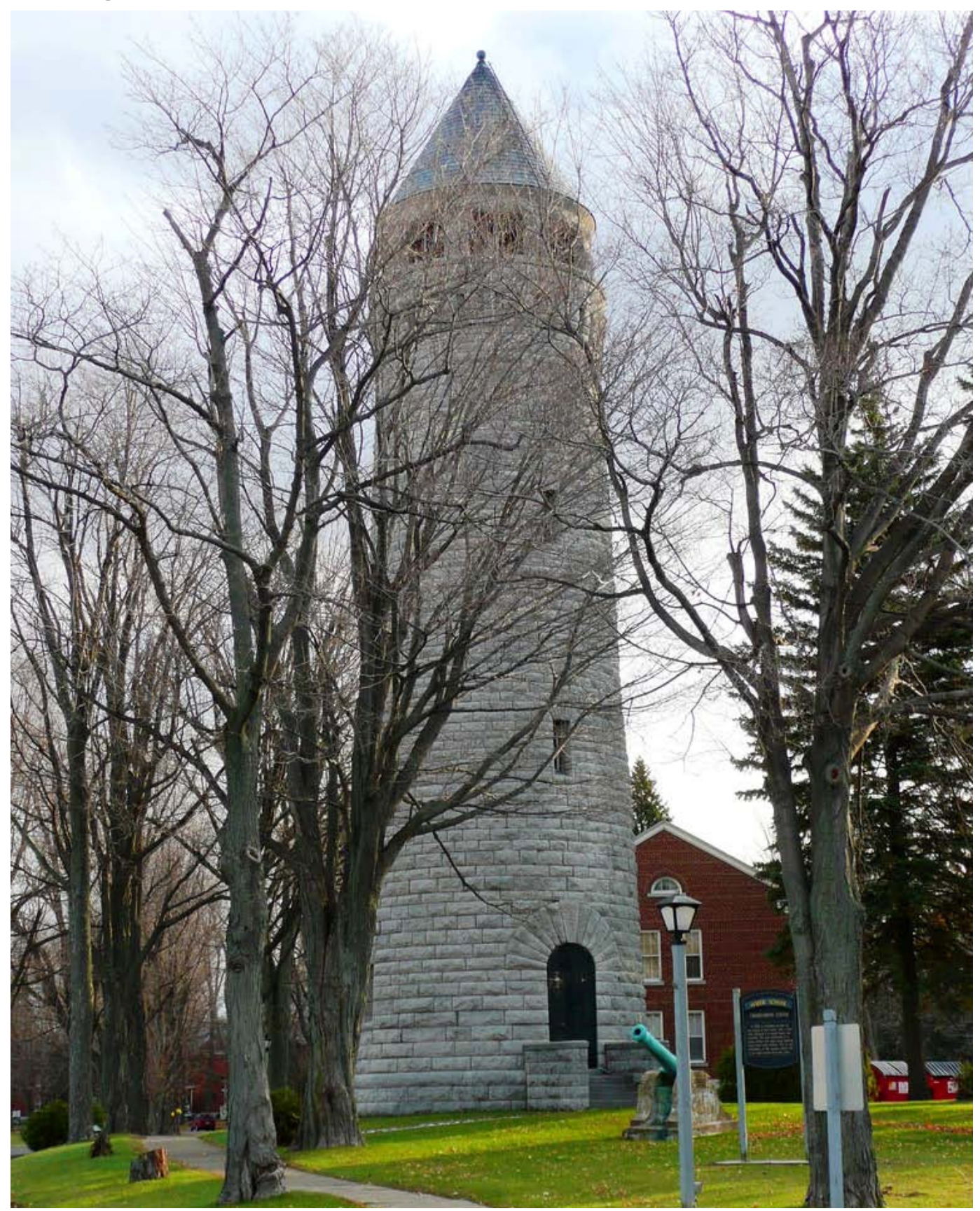

7 Hilla Becker and Bernd Becker, "Ammunition and Explosive Storage for the Navy (1939-1989) and the Air Becher.: (Cambridge, The MIT Press, 1988), 13. 
Figure 14. Fort Sheridan, Illinois, water tower (ERDC-CERL, 2010).

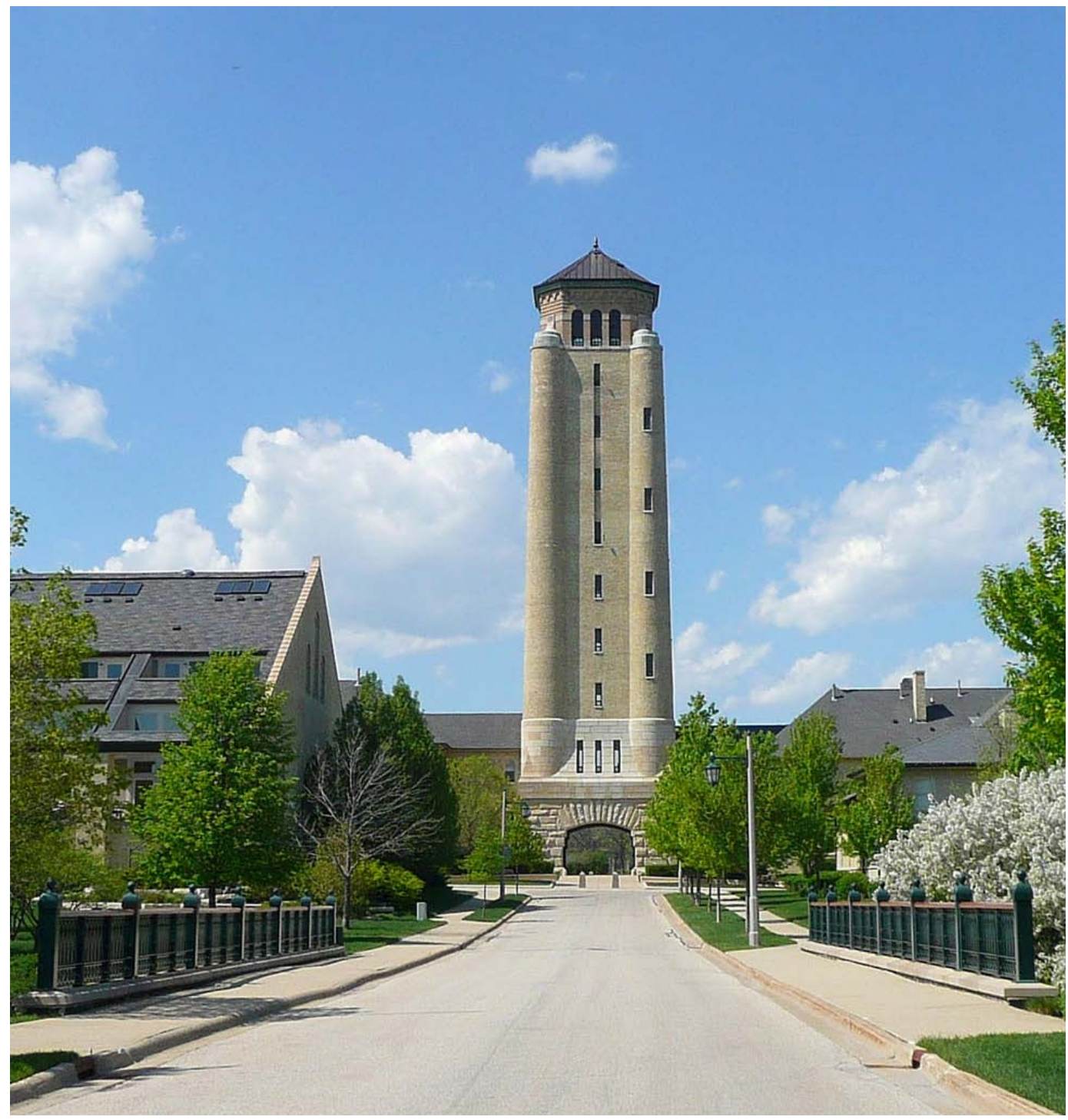


Figure 15. Collinsville, Illinois, bottle-shaped water tower (ERDC-CERL, 2010).

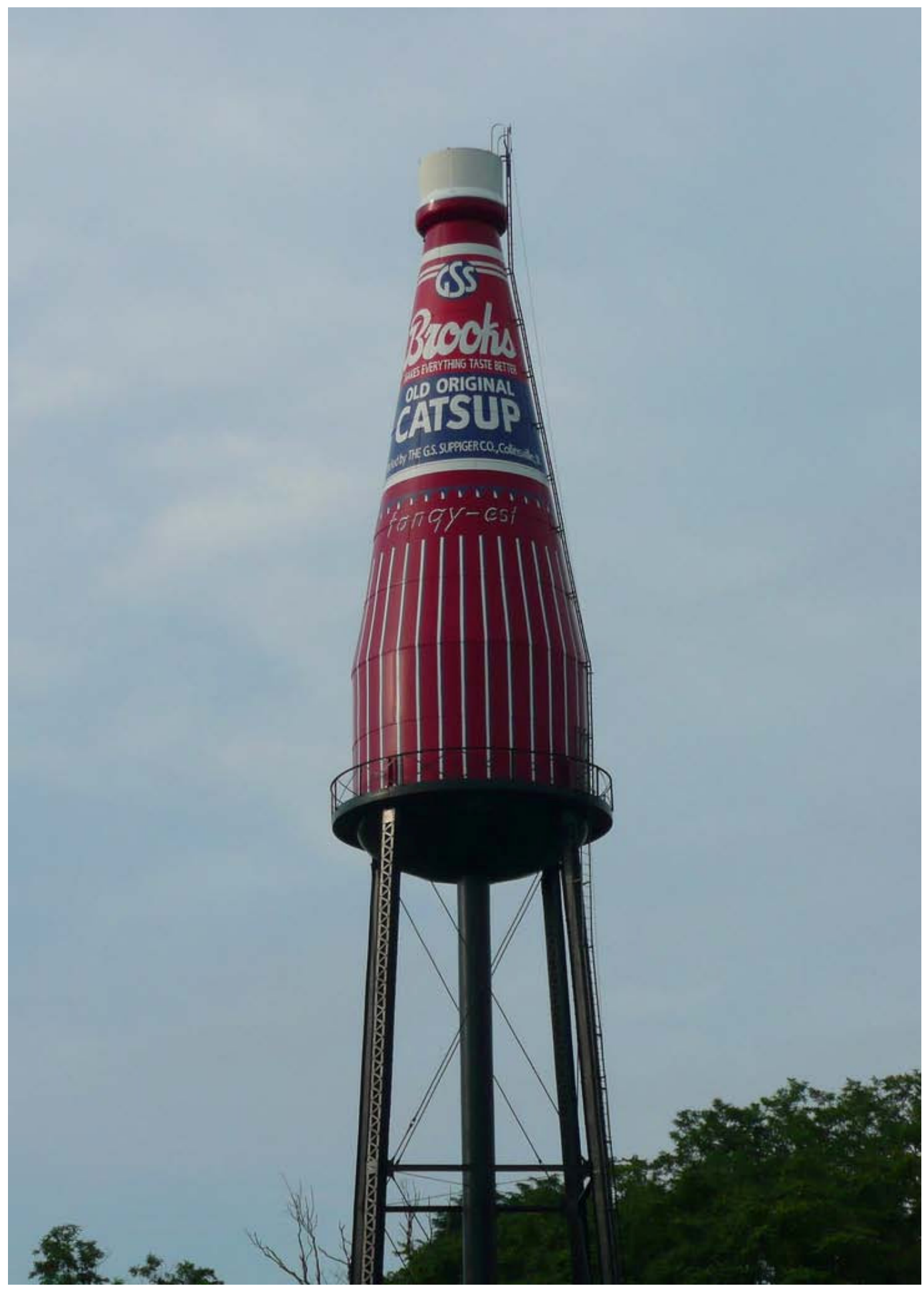

\subsection{Receiving reservoirs}

The primary purpose of receiving reservoirs is to store water versus to pressurize water systems like standpipes and elevated water tanks, 
although reservoirs can also pressurize a system, depending on its elevation. Receiving reservoirs generally are located close to their users at the end of a water distribution system like New York's Central Park Reservoir (1,000,000,000 gallons) which was constructed in 1858 , receiving water from the Croton Aqueduct, or Los Angeles' Silver Lake reservoir (Figure 16), which was constructed in 1906 and received water from the Los Angeles Aqueduct. Due to the size of the population and the size of the reservoir, these types of reservoirs resemble lakes.

Figure 16. View of Los Angeles' Silver Lake Reservoir in 1973 (Los Angeles Public Library image 46330).

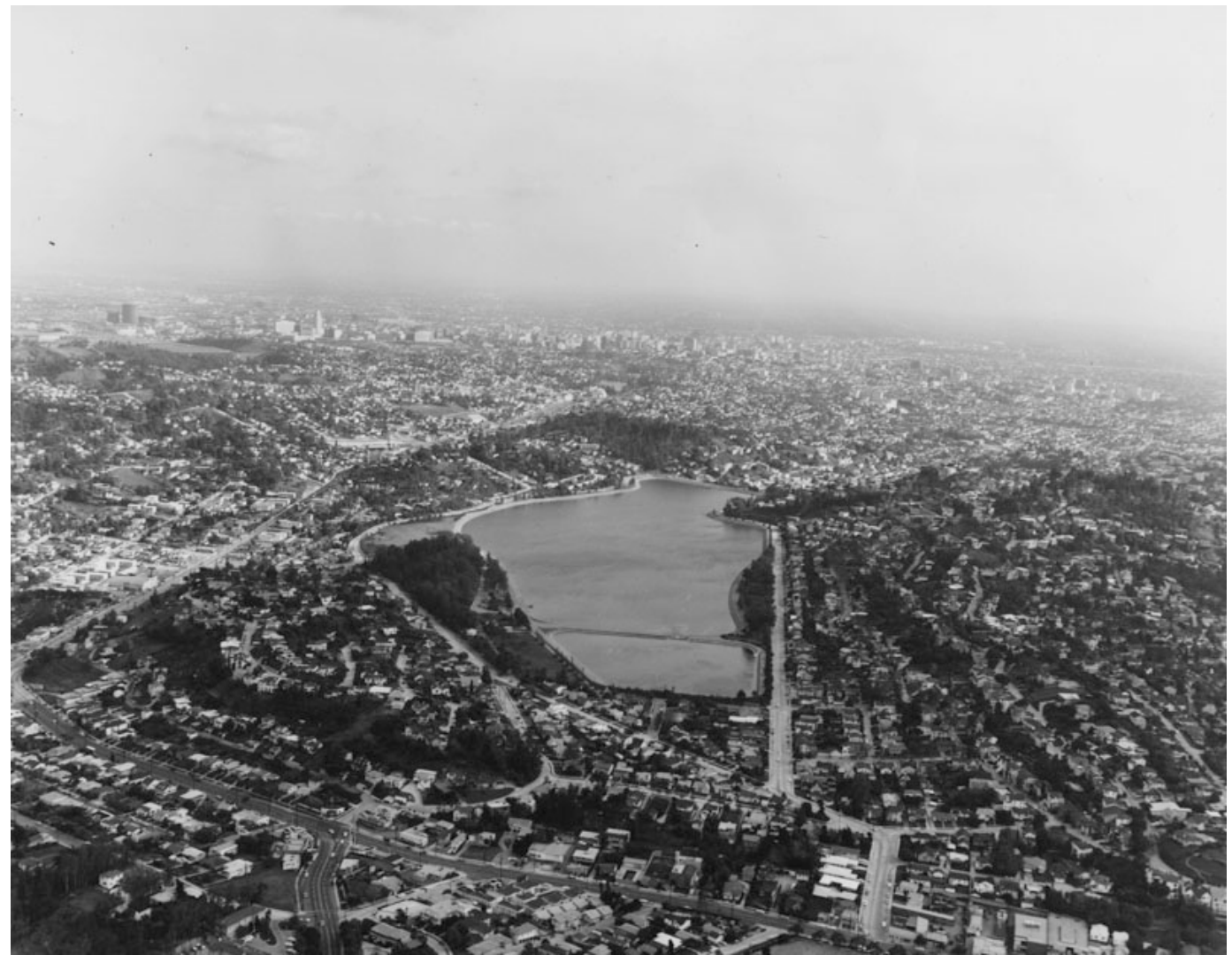

Cities and towns in the United States utilized a variety of receiving/distributing reservoirs, depending on their population, water use, and water system. New York's Croton Distributing Reservoir at $42^{\text {nd }}$ Street and $6^{\text {th }}$ Avenue was constructed in 1839 (Figure 17); Washington, D.C. constructed the McMillan Reservoir in 1902; St Paul, Minnesota constructed a 30-million gallon concrete storage reservoir in 1919; and Topeka, Kansas, constructed a 10-million gallon concrete underground storage reservoir in 1931. 
Figure 17. View of New York's Croton Reservoir in 1899 (New York Public Library).

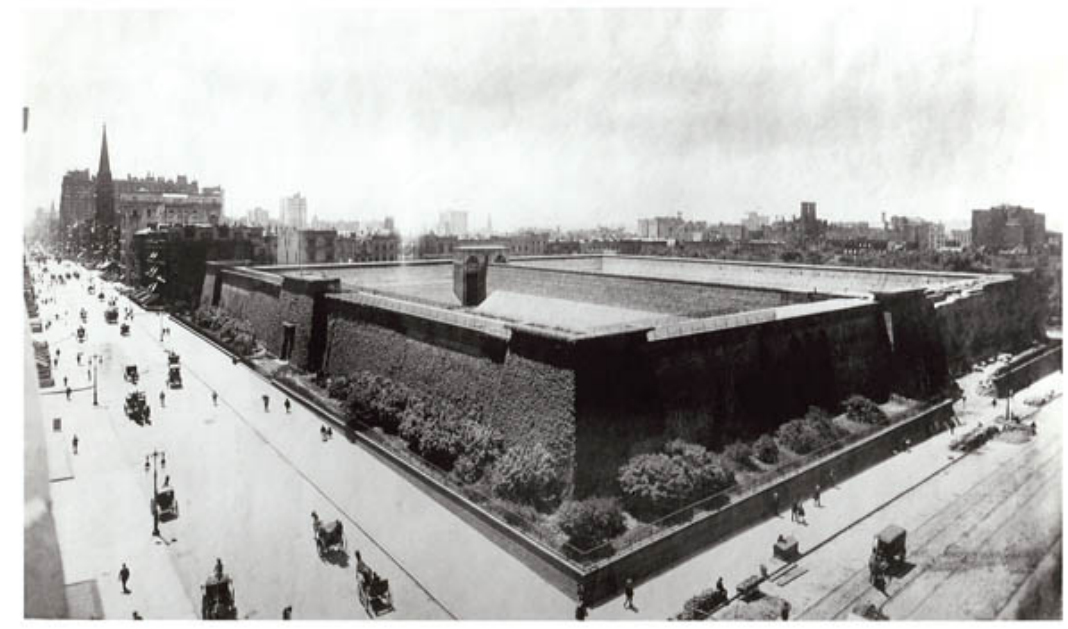

Concrete water tanks were developed by the railroads in the early part of the twentieth century, as longer-lasting tanks than the wood tanks with steel tension rods. Typically these concrete tanks were too small for most urban water supply systems, and the use of concrete as a reservoir construction material did not become useful for large systems until after World War II (WWII), with the advent of pre-stressed concrete.

\subsection{Water system at Fort Huachuca}

When Fort Huachuca was first established as Camp Huachuca in 1877, it relied on wells sunk into the Huachuca Creek and springs in the Huachuca Canyon for water supply being transferred to the camp by water wagon. By 1884 a gravity supply system was completed bringing spring water down by an above ground pipeline and into a 250,000 gallon storage reservoir on a ridge above the post (Figure 18). 8 The gravity supply system, combined with strict water consumption rules, was employed until 1911, when the population of Fort Huachuca grew, and new sources of water were sought. 9

\footnotetext{
8 Rand F. Herbert, Fort Huachuca: A Century of Development and Changing Missions, 1877-1977 (Davis, CA: Jackson Research Projects, 1990), p. i

9 Headman, Ferguson \& Carollo Architects and Engineers, Completion Report: Cantonment Construction Fort Huachuca (Phoenix, AZ: Headman, Ferguson \& Carollo Architects and Engineers, May 10, 1941), 
Figure 18. The Old Post Reservoir dates to 1884 and is shown in this photo from 1900 (Herbert 1990, 57).

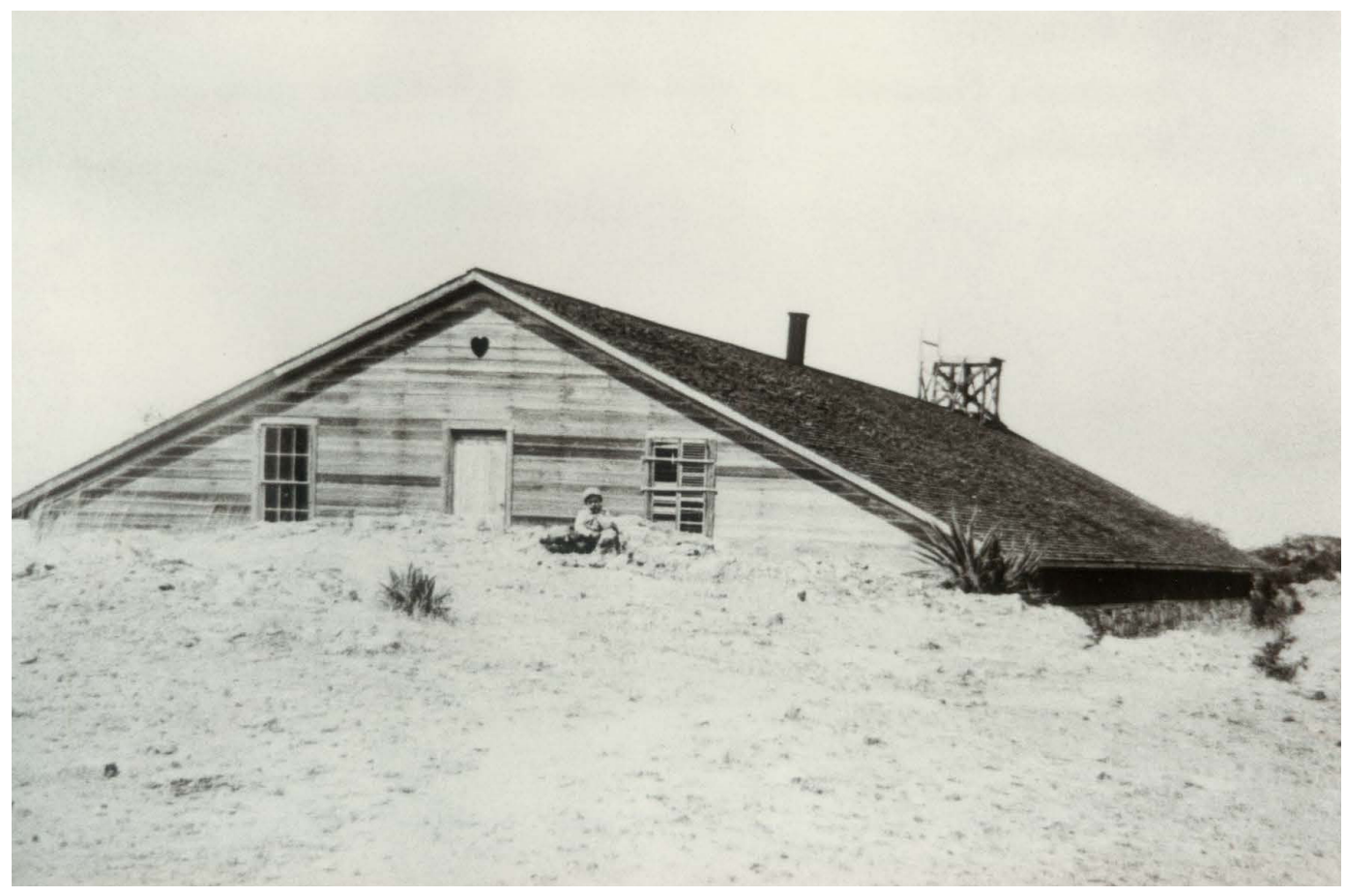

In October 1911, a 45,000 foot pipeline was constructed to tap the springs in Garden Canyon, nine miles away. While tapping into the springs added a more steady supply of water to Fort Huachuca, water shortages were common at times of drought. ${ }^{10}$ The Army approved a contract in 1929 for deep wells to be sunk at the Garden and Huachuca Canyons to reach groundwater supplies; by 1934, the Garden Canyon well was the only one completed and was not a reliable source of water in droughts.

The discovery of groundwater near the East Gate of Fort Huachuca became the Huachuca's most reliable source of water. In 1936, the first deep-well was drilled 290 feet west of the East Gate; it became operational by mid-July, though it was not in operation for a long time. ${ }^{11}$ The Army then re-allocated WPA funds to construct more wells on the East Range Well Field and to upgrade existing water sources to meet the growing demands of Fort Huachuca.

Starting in 1939, two deep wells were drilled on the East Range Well Field (Figure 19 and Figure 20), adding a combined capacity of 1,725,000

10 Herbert, Fort Huachuca: A Century of Development, 77.

11 Headman, Ferguson \& Carollo, Completion Report: Cantonment Construction Fort Huachuca, 21. 
gallons per day to the area. ${ }^{12}$ Drilled 90 feet west of the 1936 well, Well \#1 (Facility 90017) was constructed in 1939 and eliminated the need for water rationing at Fort Huachuca.13 One year later, a second well (Well \#2;

Facility 90013) was drilled 500 feet west of Well \#1 $1^{14}$ (Figure 20, Figure 21 and Figure 22).

Figure 19. 1941 water supply (Herbert 1990, 121).

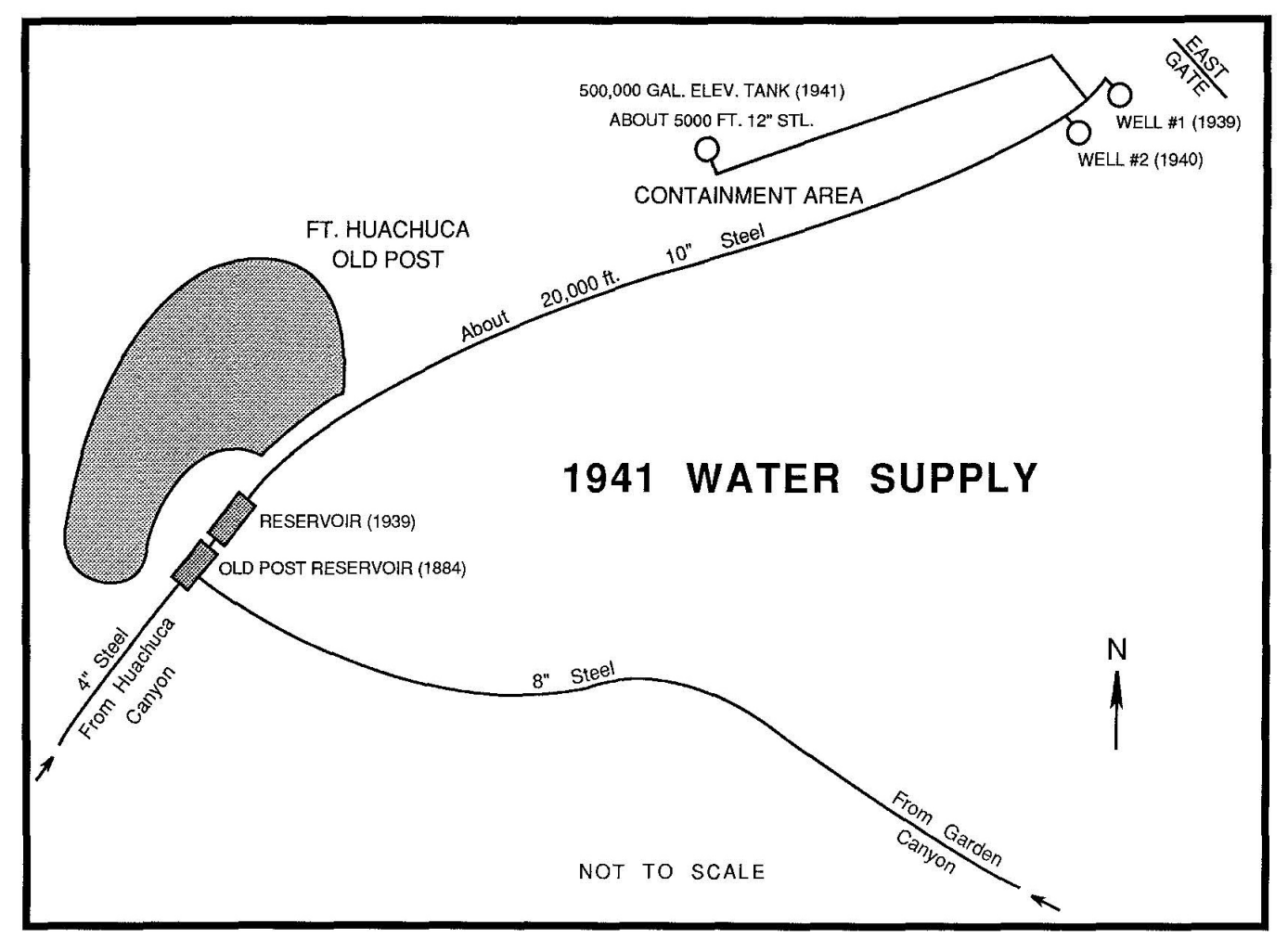

12 Herbert, Fort Huachuca: A Century of Development, 113

13 Angel Tomes, Architectural Survey, Documentation, and Evaluation of 110 Buildings and Structures at Fort Huachuca, Arizona (Tucson, AZ: Statistical Research, 2013), 162.

14 ibid.,156. 
Figure 20. Location of Fort Huachuca Wells \#1 and \#2 at the east gate, 1943 (NARA Riverside RG77-Folder 2).

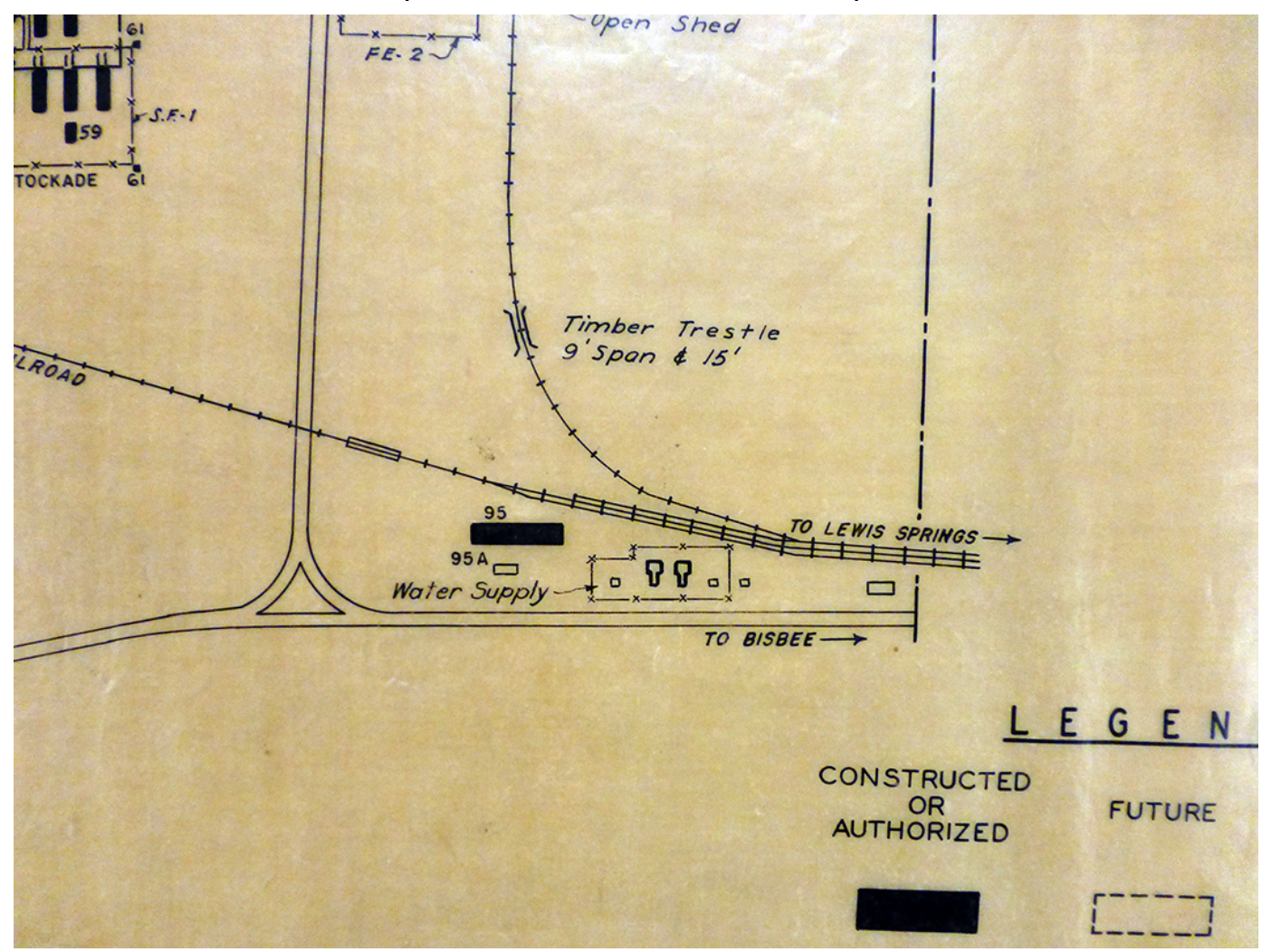

Figure 21. Head of turbine pump for Well \#2 installed on concrete foundation with workmen starting wall forms for the pump house, 1939 (NARA College Park RG77-133).

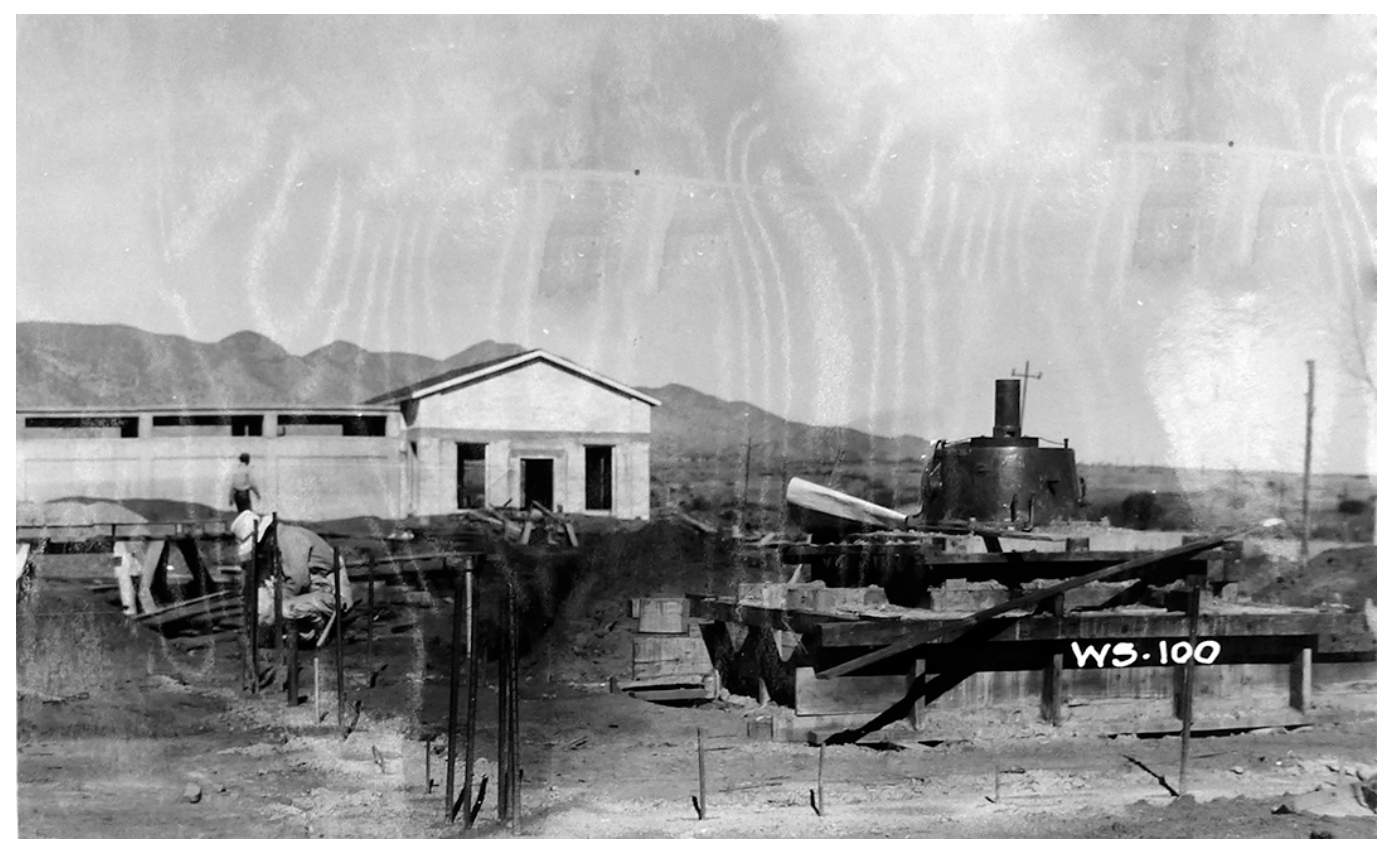


Figure 22. Well house for Well \#2 under construction in 1941 (NARA College Park RG77-133).

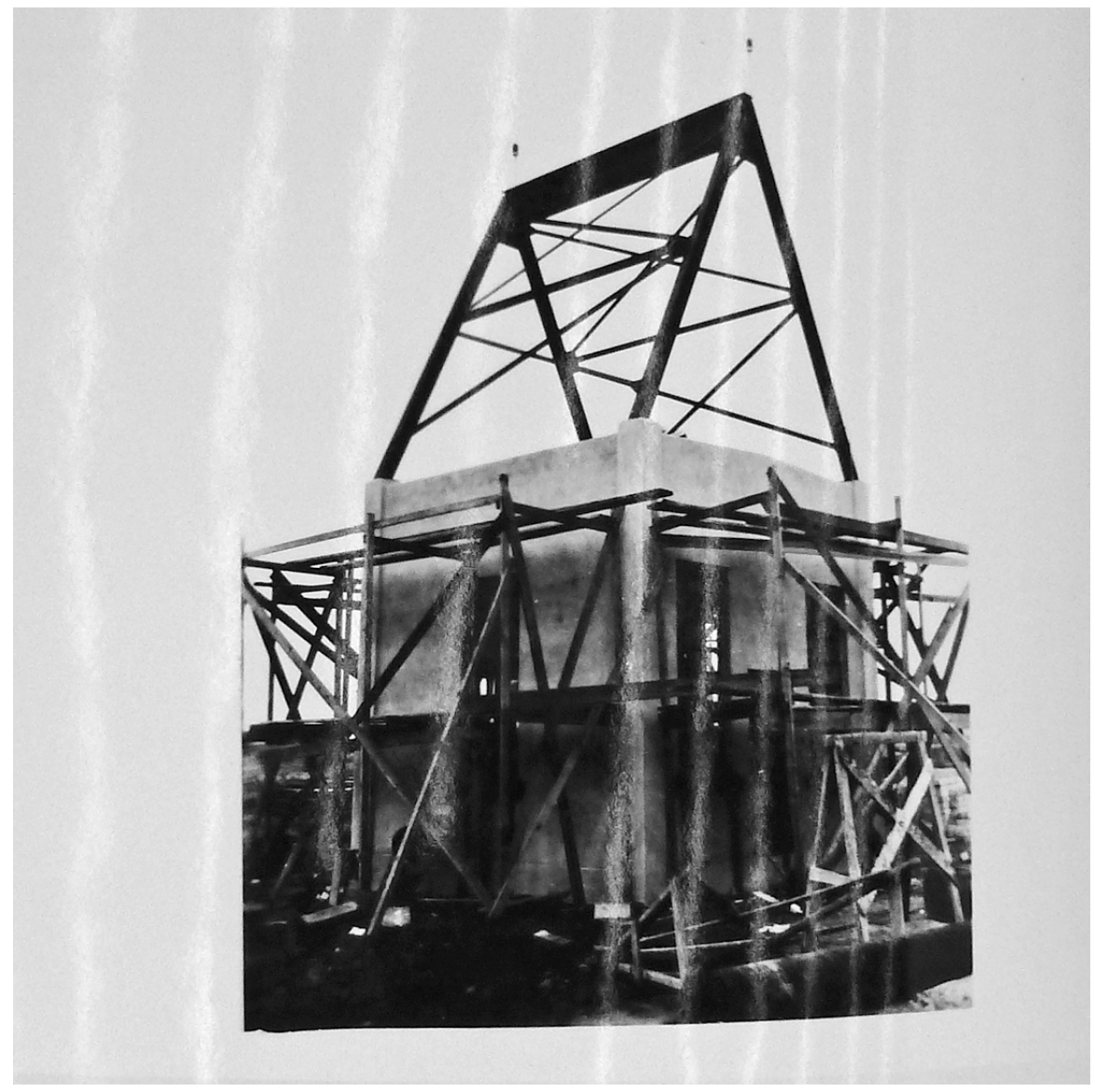

In late 1941 and early 1942, Fort Huachuca was greatly expanded in the area between the original cantonment and the East Gate (Figure 23). With a new and higher demand for water, the Army drilled three new deep wells: Well \#3 (Facility 90431), Well \#4 (Facility 90672), and Well \#5 (Facility 90860) ${ }^{15}$ (Figure 24). During this time, twin 500,000-gallon elevated tanks were erected. The first (Facility 49001) was manufactured by the Allison Steel Manufacturing Company and was erected in 1941 on the western side of the new cantonment, ${ }^{16}$ and the second elevated tank (Facility 70411) was erected in early 1942 (Figure 25). A ground-level water tank (Facility 61609) that could hold three million gallons was also constructed between the original cantonment and the new cantonment. ${ }^{17}$

\footnotetext{
15 Herbert, Fort Huachuca: A Century of Development, 122.

16 Headman, Ferguson \& Carollo, Completion Report: Cantonment Construction Fort Huachuca, .21

17 S. Elizabeth Valenzuela, FY12 SRM Facilities and Demolition Projects: Documentation and National Register Evaluation of 29 Buildings on Fort Huachuca, Arizona (Austin, TX: Valenzuela Preservation Studio, 2011), 203.
} 
The elevated water tank (Facility 49001, constructed in 1941) is a 500,000 gallon water tank that stands 90 feet tall overall and is at an elevation of 4,809 feet, with a water tank that is 29 feet high and 59 feet wide (Figure 26).

Figure 23 Layout of Fort Huachuca in 1945, showing the original cantonment on the left and the new cantonment on the right [boxes mark the location of two elevated water tanks (Fort Huachuca DPW).

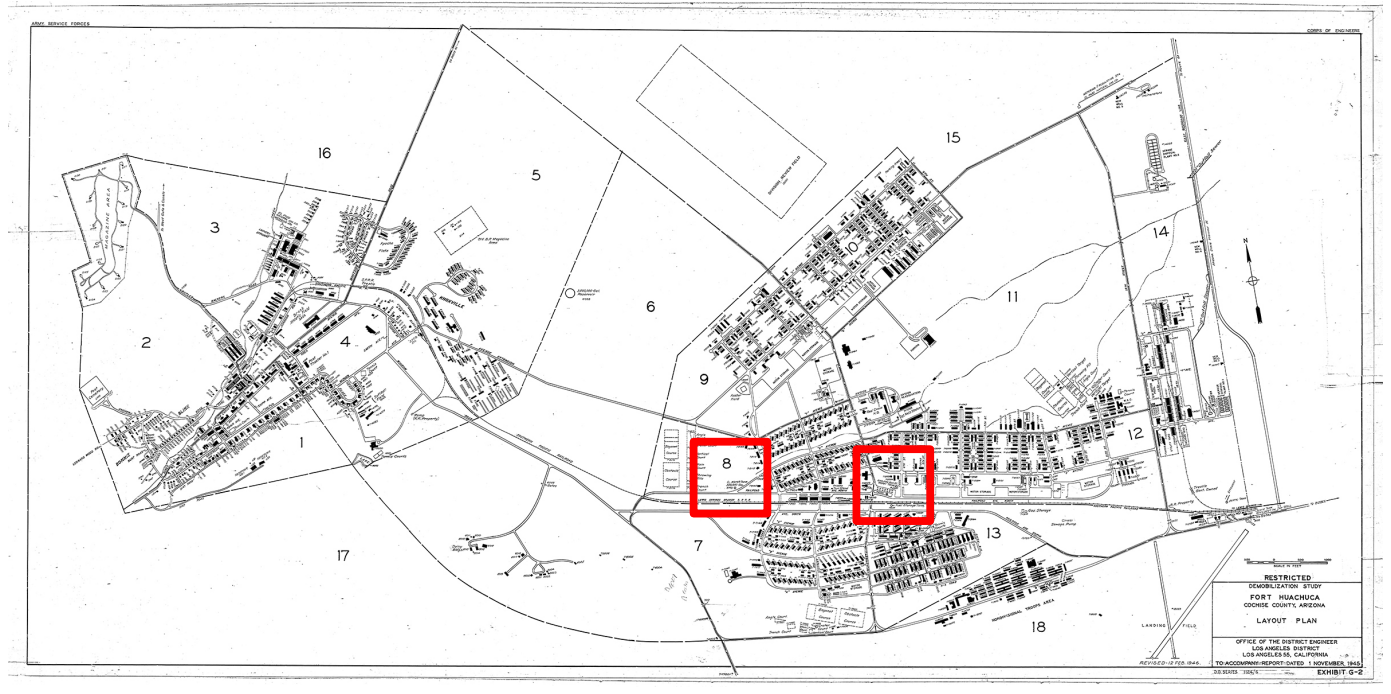


Figure 24. Location of the five wells on the east boundary (NARA Riverside RG77-Folder 2).

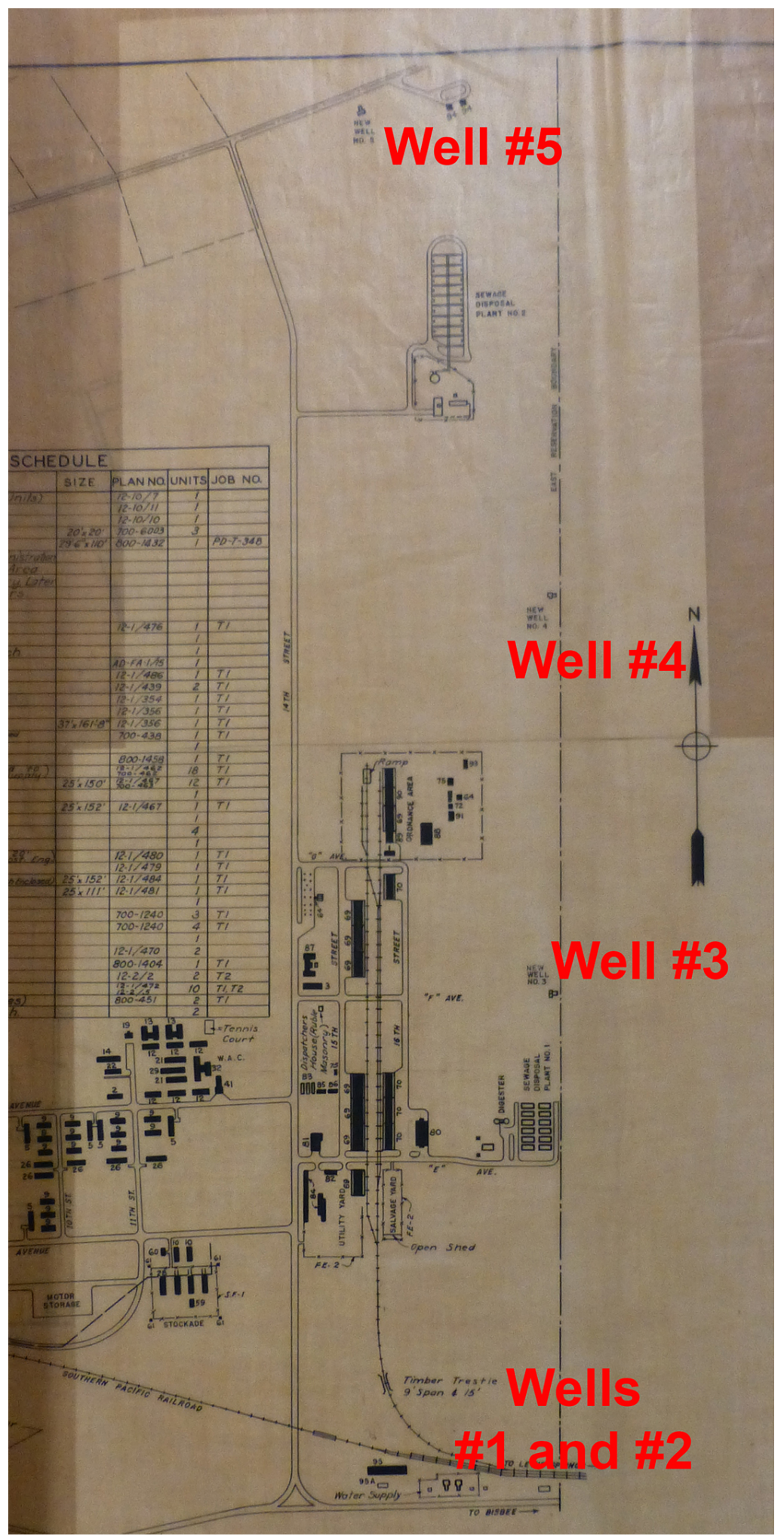


Figure 25. Aerial of Fort Huachuca, looking east with the twin elevated water tanks visible in center [marked by red boxes], 1945 (Fort Huachuca Museum Collection).

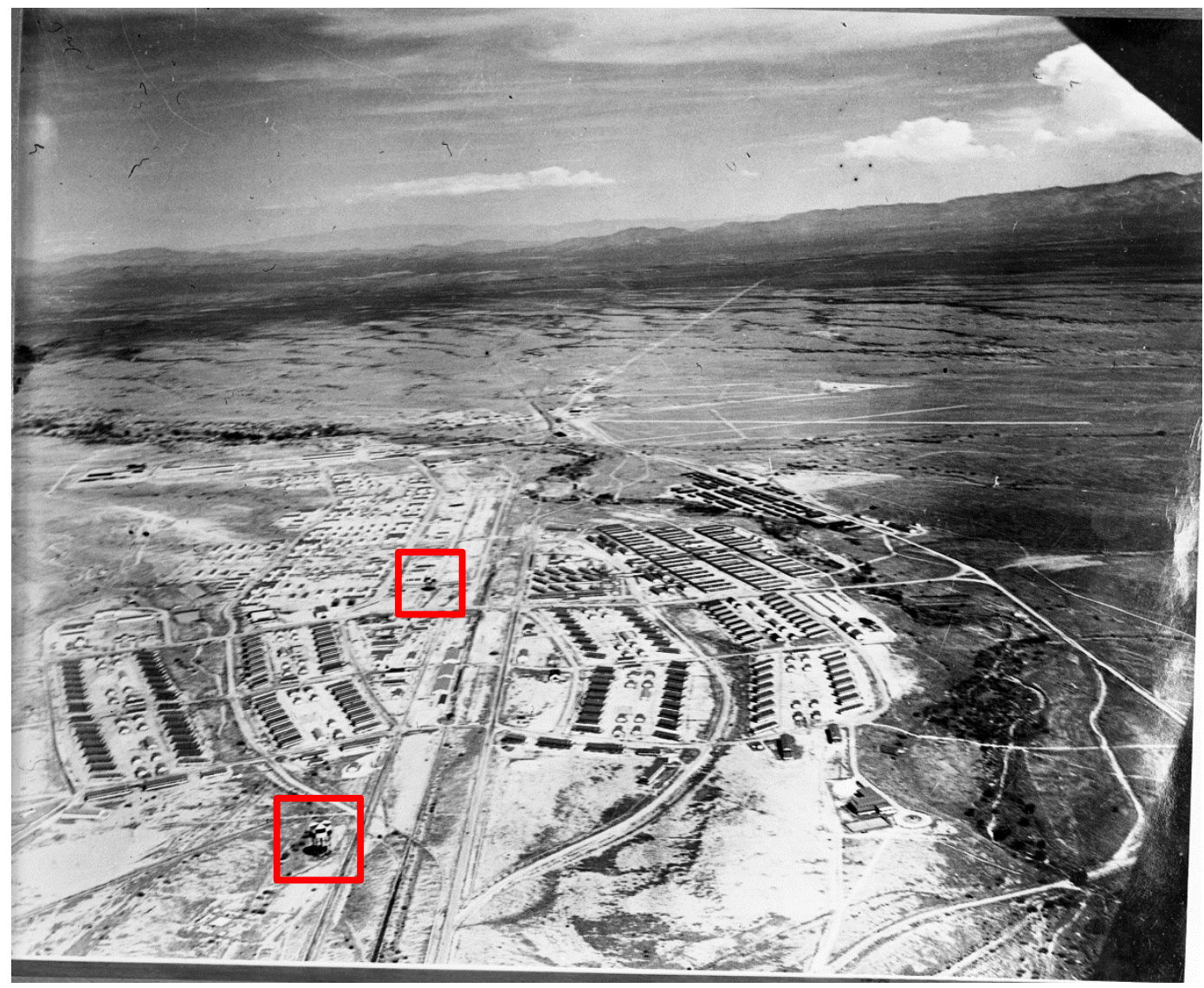


Figure 26. View of the elevated water tank (Facility 49001), 1 May 1941

(NARA College Park RG77-133).

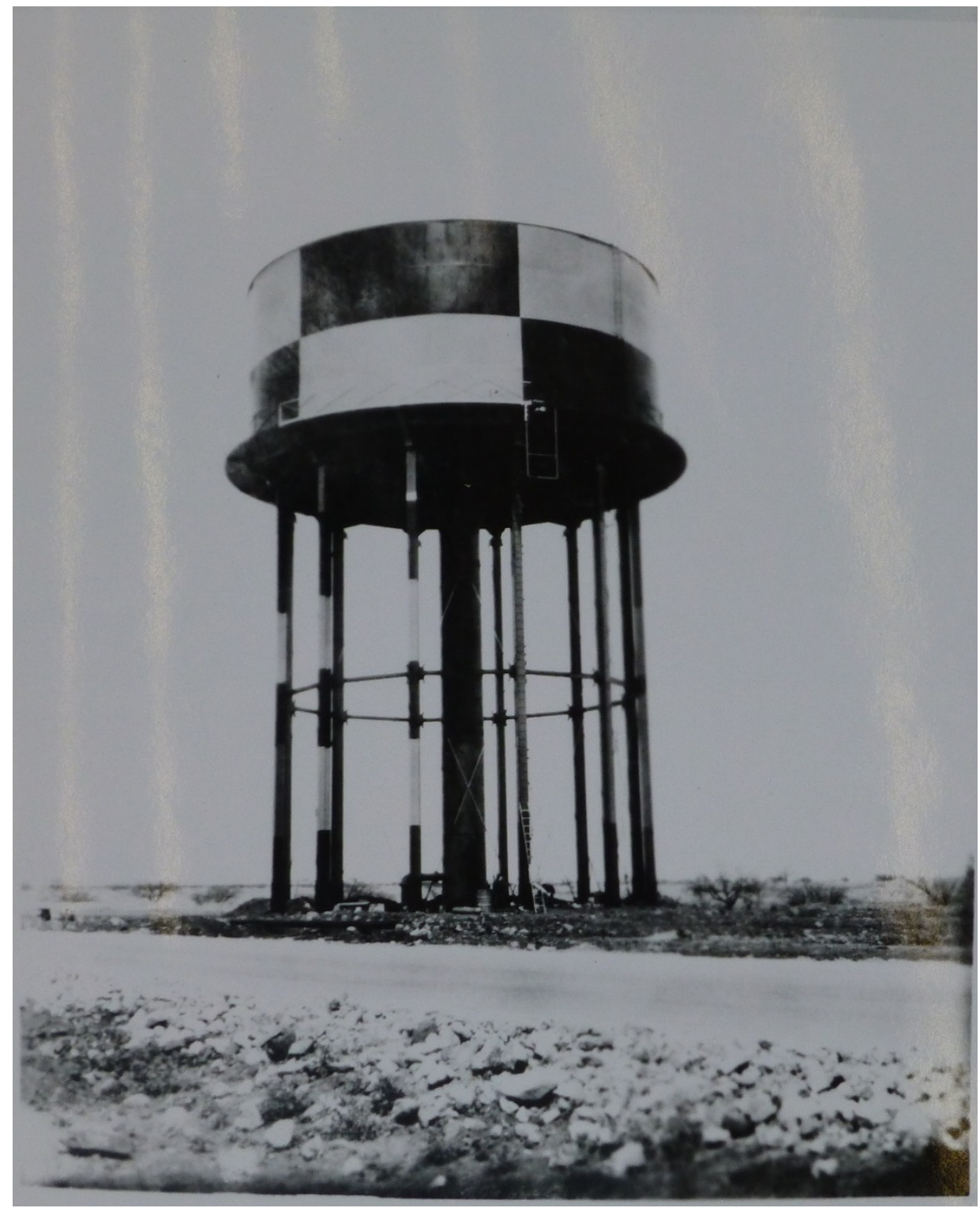

Buildings and structures in the WWII cantonment were sold and demolished over a period of years after the state of Arizona acquired the property in $1947 .{ }^{18}$ By 1954 , much of the WWII temporary buildings on the north side of the WWII cantonment were gone (Figure 27), and this area is now utilized for housing (the south side of the WWII cantonment is utilized for a large solar panel field).

18 Herbert, Fort Huachuca: A Century of Development, 149. 
Figure 27. Aerial of Fort Huachuca, looking north with the elevated water tank erected in 1941 on the top left and the elevated water tank erected in 1942 on the far right [marked by boxes], 1954. (NARA 111-SCA).

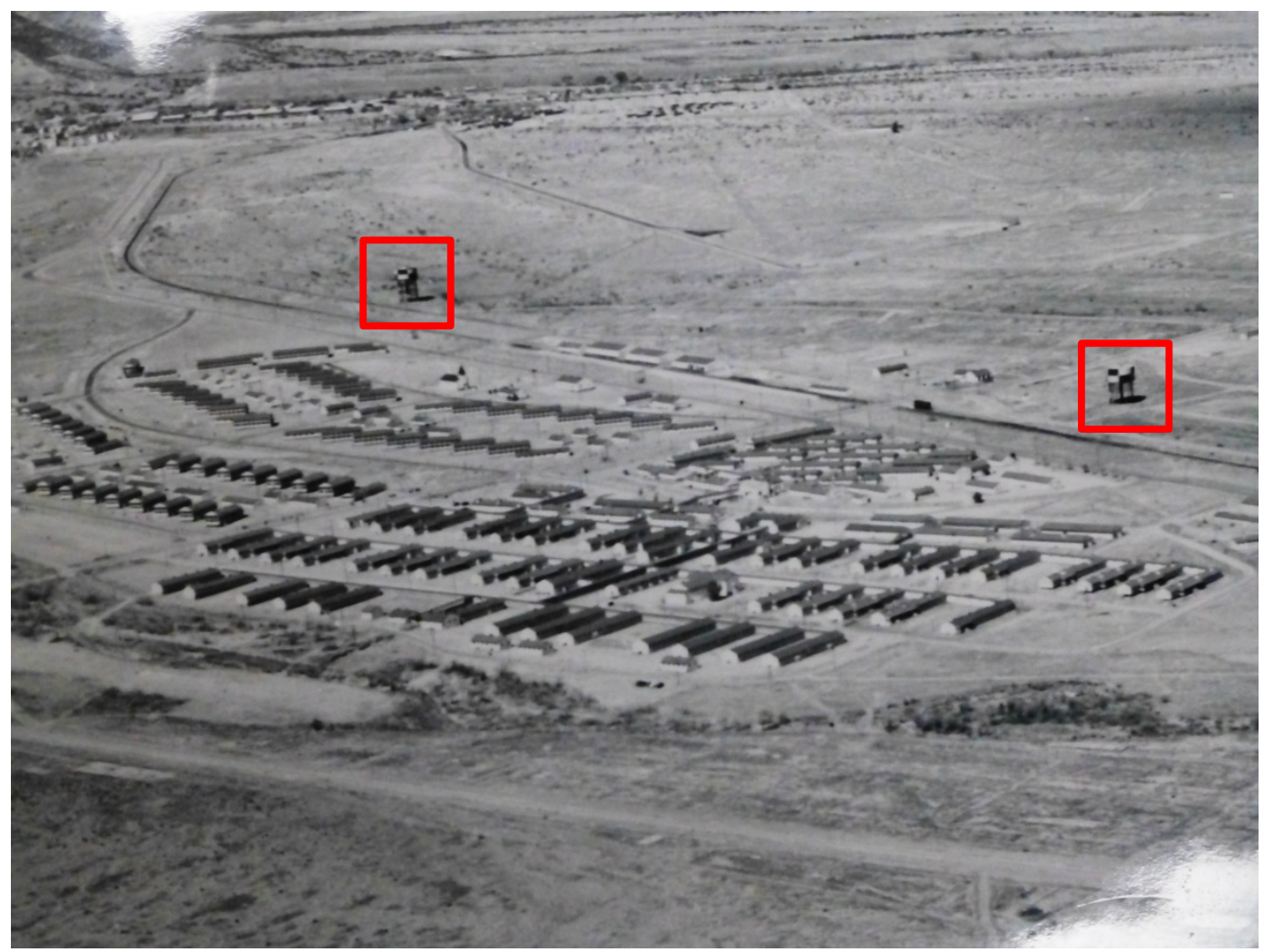

A concrete 1,500,000 gallon water reservoir (Facility 22020) was constructed in 1959 below the Old Post Reservoirs (Facility \#22001 and \#22002) ${ }^{19}$ to provide additional storage for the 575 housing units being constructed at the time (Figure 28). The completion of the 1959 water reservoir made the 1942 elevated water tank (Facility 70411) obsolete, and it was demolished in 1974 (Figure 29) (.20 Well \#6 (Facility 79692) was drilled in 1962 and currently is the last addition to the post's water supply system. ${ }^{21}$

\footnotetext{
19 Herbert, Fort Huachuca: A Century of Development, 198.

20 ibid., 228.

21 Angel Tomes, Architectural Survey, Documentation, and Evaluation of 100 Buildings and Structures at Fort Huachuca, Arizona. (Tucson, AZ: Statistical Research Inc., 2013), 51
} 
Figure 28. Concrete 1,500,000 gallon reservoir (Facility 22020), constructed in 1959 , is shown near bottom right corner in this 1960 photo

(Fort Huachuca Museum Collection).

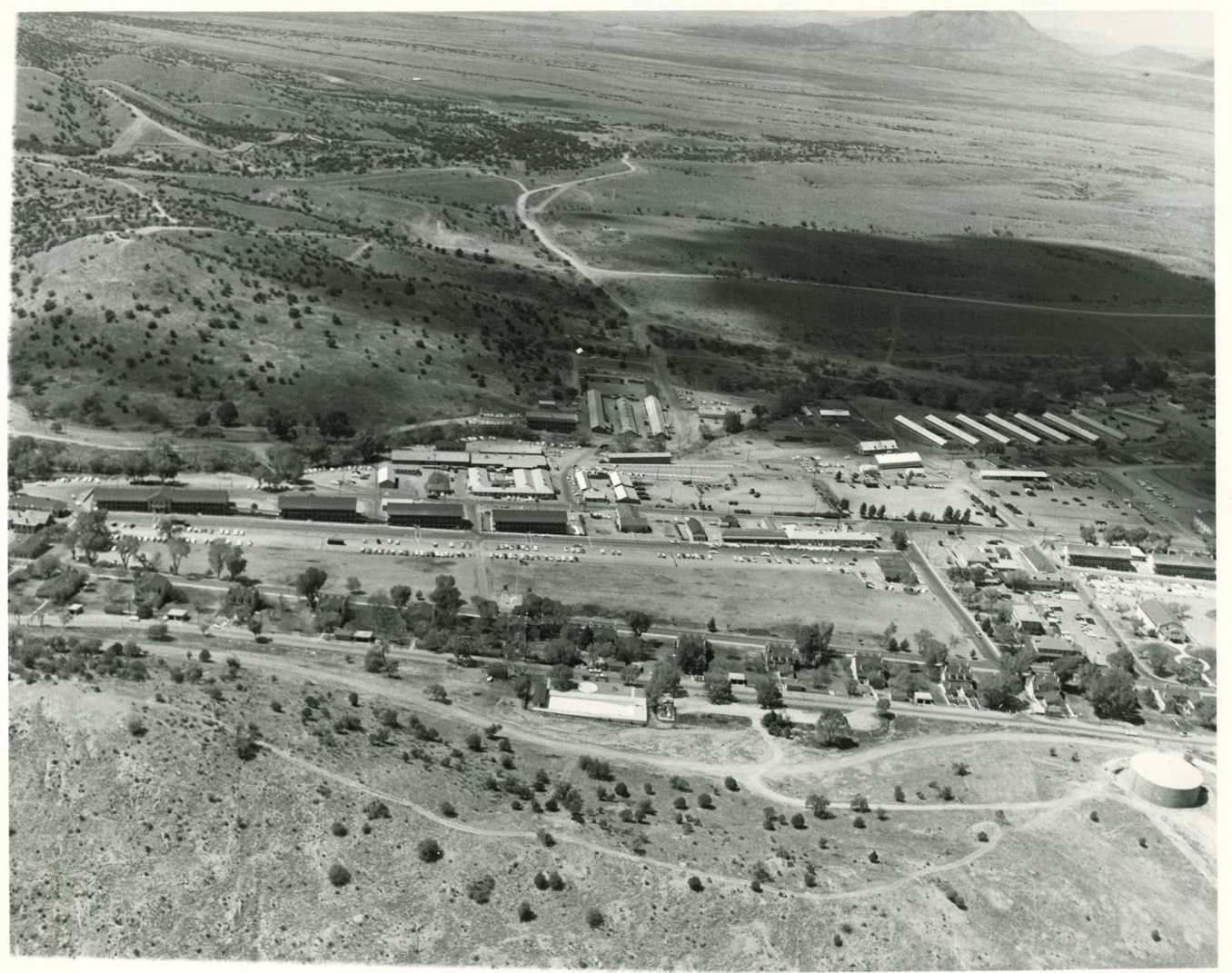


Figure 29. Deconstruction of the 1942 elevated water tank (Facility 70411) in 1974 (Fort Huachuca Museum Collection).

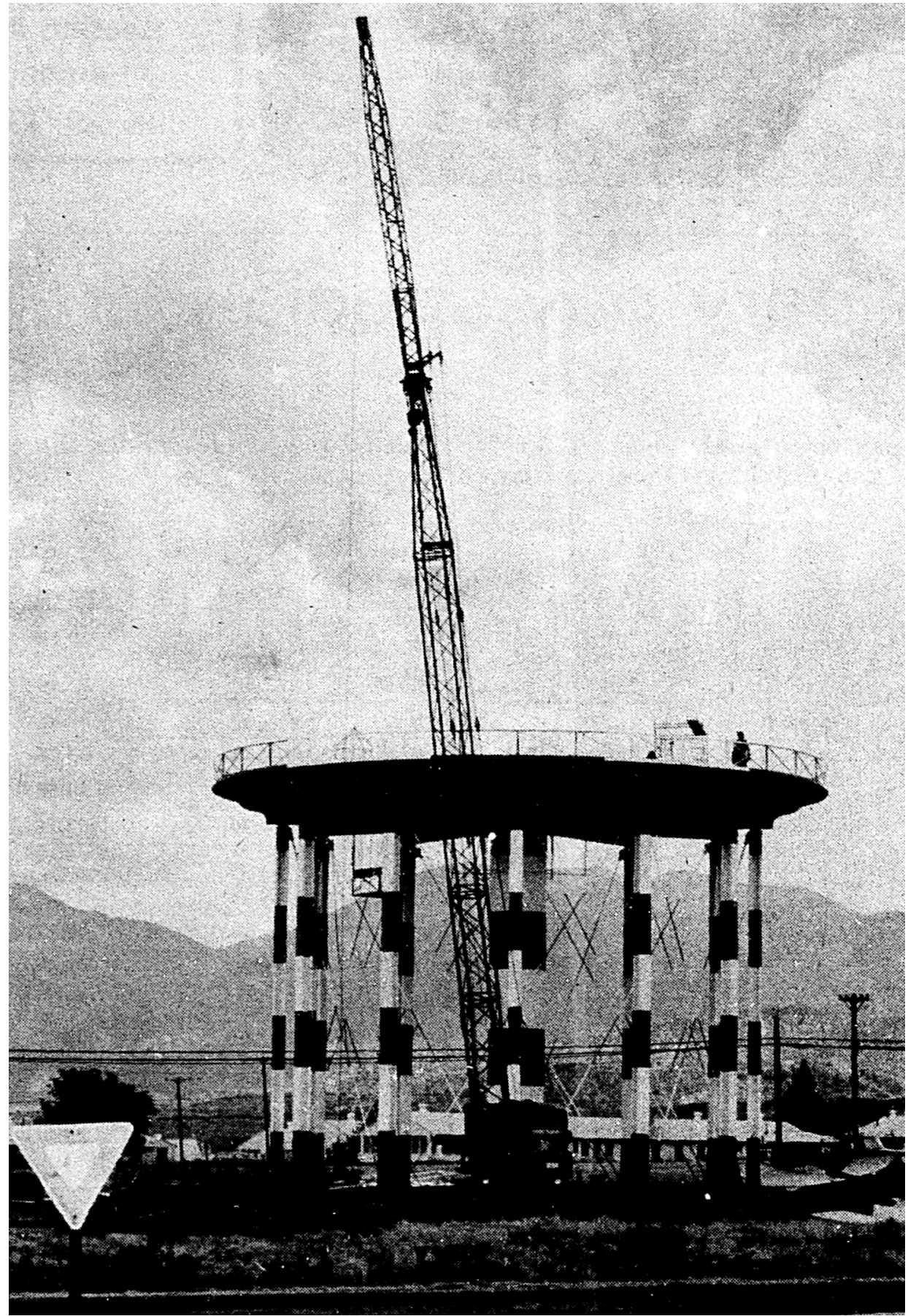

The elevated water tank (Facility 49001) and 1,500,000 gallon water reservoir at the base of Reservoir Hill (Facility 22020) are currently filled by the six water wells. Currently, the elevated water tank is only used to support fire protection in the cantonment. The 1,500,000 gallon water reservoir provides water to a smaller segment of cantonment. 


\section{Inventory Results and Conclusion (Determination of Eligibility)}

\subsection{Categories of historic properties}

The identification of historically significant properties is achieved through evaluation of their position within a larger historic context. According to the NRHP, historic contexts are defined as “...the patterns, themes, or trends in history by which a specific occurrence, property, or site is understood, and its meaning (and ultimately its significance) within prehistory or history is made clear. ${ }^{22} \mathrm{~A}$ historic property is determined significant or not significant by applying standardized National Register Criteria for Evaluation to property within its historical context. The NRHP categorizes significant properties as buildings, sites, districts, structures, or objects. ${ }^{23}$ The definitions of these property types follow:

Building: A building is created principally to shelter any form of human activity. Examples of buildings include: administration building, house, barn, stable, train station, church, or shed.

Structure: Structures are distinguished from buildings by being functional constructions made for purposes other than creating human shelter. Examples of structures include: aircraft hangars, bandstands, bridges, canals, fences, kilns, or windmills.

Object: The term object is used to distinguish from buildings and structures those constructions that are primarily artistic in nature or are relatively small in scale and simply constructed. Although it may be, by nature or design, movable, an object is associated with a specific setting or environment. Examples of objects include boundary markers, fountains, monuments, sculptures or statues.

Site: A site is the location of a significant event, a prehistoric or historic occupation or activity, or a building or structure, whether standing, ruined, or vanished, where the location itself possesses historic, cultural, or archeological value regardless of the value of any existing structure. Examples of sites include: battlefield, campsite, ceremonial site, designed landscape, rock shelter, or village site.

District: A district possesses a significant concentration, linkage, or continuity of sites, buildings, structures, or objects united historically or aesthetically by plan or physical development. A district can comprise both features that lack individual distinction and individually distinctive features that serve as focal points. A group of features lacking in individual distinction may even be considered eligible if the grouping achieves significance as a whole within its

\footnotetext{
22 National Park Service. National Register Bulletin \#15: How to Apply the National Register Criteria for Evaluation (Washington, DC: U.S. Department of the Interior, National Park Service, 1997), 7.

23 ibid., 9.
} 
historic context. While a district derives its importance from being a unified entity, it can contain buildings, structures, sites, objects, or open spaces that do not contribute to the significance of the district if these properties do not adversely affect the district's integrity.

\subsection{Criteria for evaluation}

The National Register Criteria for Evaluation define how historic properties are significant by categorizing a property's associations with important historic qualifiers. The National Register Bulletin \#15: How to Apply the National Register Criteria for Evaluation lists four major criteria to which a historic property can be associated: Criterion Aimportant events, Criterion B-persons, Criterion C-importance in design and construction, and Criterion $\mathrm{D}$-information potential. Although there are other criteria considerations, the four major criteria are described in more detail below:

A. Event is associated with events that have made a significant contribution to the broad patterns of our history; or

B. Person is associated with the lives of persons significant in our past; or

C. Design/Construction embody the distinctive characteristics of a type, period, or method of construction, or that represent the work of a master, or that possess high artistic values, or that represent a significant and distinguishable entity whose components may lack individual distinction; or

D. Information Potential where the property has yielded, or is likely to yield, information important in prehistory or history.

\subsection{Aspects of historic integrity}

In addition to possessing historical significance, to be eligible to the NRHP properties must also retain sufficient physical integrity of features in order to convey its significance. ${ }^{24}$ Historic properties both retain integrity and convey their significance, or they do not. The National Register recognizes seven aspects or qualities of a property that define the concept of integrity. To retain historic integrity, a property must possess several, and usually most, of the seven aspects. The retention of specific aspects of historic integrity is paramount for a property to convey its significance. Determining which of these aspects are most important to a particular property requires knowing why, where, and when the property is significant. The seven aspects of integrity are summarized from National

\footnotetext{
24 National Park Service. National Register Bulletin \#15: How to Apply the National Register Criteria for Evaluation, 44-45.
} 


\section{Register Bulletin \#15: How to Apply the National Register Criteria for Evaluation:25}

\section{Location}

Location is the place where the historic property was constructed or the place where the historic event occurred.

\section{Design}

Design is the combination of elements that create the form, plan, space, structure, and style of a property. It results from conscious decisions made during the original conception and planning of a property (or its significant alteration) and applies to activities as diverse as community planning, engineering, architecture, and landscape architecture. Design includes such elements as organization of space, proportion, scale, technology, ornamentation, and materials.

\section{Setting}

Setting is the physical environment of a historic property. Setting refers to the character of the place in which the property played its historical role. It involves how, not just where, the property is situated and its relationship to surrounding features and open space.

\section{Materials}

Materials are the physical elements that were combined or deposited during a particular period of time and in a particular pattern or configuration to form an historic property.

\section{Workmanship}

Workmanship is the physical evidence of the crafts of a particular culture or people during any given period in history or prehistory.

\section{Feeling}

Feeling is a property's expression of the aesthetic or historic sense of a particular time period.

\section{Association}

Association is the direct link between an important historic event or person and a historic property.

Integrity has very specific connotations in defining historic and cultural resources. Integrity is the authenticity of physical characteristics from which resources obtain their significance. Historic properties convey their significance through their integrity. Districts and individual resources are considered significant if they possess a majority of these seven aspects. Properties in a historic district are classified as either "contributing or non-contributing" resources. Contributing resources date from the historic

\footnotetext{
25 National Park Service. National Register Bulletin \#15: How to Apply the National Register Criteria for Evaluation.
} 
period of significance established for the district. They contribute to the significance and character of the district through their historical associations and/or architectural values. Noncontributing resources are those that, due to the date of construction, alterations, or other factors, do not contribute to the district's historic significance or character.

\subsection{Significance}

The period of significance for the elevated water tank (Facility 49001) was its date of construction, 1941, and the period of significance for the 1,500,000 gallon reservoir (Facility 22020) was its date of construction, 1959.

\subsubsection{National, state, or local significance}

The researchers were tasked with recommending the eligibility or ineligibility of the elevated water tank and the reservoir. The elevated water tank and reservoir, while part of the water supply of Fort Huachuca, are not significant to the mission of Fort Huachuca, and they do not, in and of themselves, have significance at the national, state, or local level for either engineering or design.

\subsection{Final determinations of eligibility}

The identification of historically significant properties is achieved only through an evaluation which associates a property within a larger historic context. According to the NRHP, "Historic contexts are those patterns, themes, or trends in history by which a specific occurrence, property, or site is understood and its meaning (and ultimately its significance) within prehistory or history is made clear." 26 Therefore, to qualify as historic, a property must have an association with a relevant historic context as well as retain its physical integrity, through which its historic significance is conveyed.

It is the determination of this report that the elevated water tank (Facility 49001) erected in 1941 is individually NOT ELIGIBLE to the NRHP due to the lack of significance for construction, engineering, or role under any of the four Criteria for Evaluation. The elevated water tank is not significant to the mission of Fort Huachuca and under Criterion A, it is not

\footnotetext{
26 National Park Service. National Register Bulletin \#15: How to Apply the National Register Criteria for Evaluation, 7.
} 
significant to the Army at the national, state, or local levels. The design and engineering of the elevated water tank is not attributed to a master engineer under Criterion $\mathrm{C}$, and its design is typical of its era and of the Allison Steel Manufacturing Company. The demolition of its twin (erected in 1942 and demolished in 1974), and the demolition of all of the surrounding WWII Army temporary buildings, has severely impacted the historic context of the elevated water tank.

It is the determination of this report that the 1,500,000 gallon reservoir (Facility 22020) constructed in 1952 is individually NOT ELIGIBLE to the NRHP due to the lack of significance for construction, engineering, or role under any of the four Criteria for Evaluation. The 1,500,000 gallon reservoir is not significant to the mission of Fort Huachuca, and under Criterion A, it is not significant to the Army at the national, state, or local levels. The design and engineering of the 1,500,000 gallon reservoir is not attributed to a master engineer under Criterion $\mathrm{C}$, and its design is typical of its era. The 1,500,000 gallon reservoir (Facility 22020) is not part of a larger historic district. 


\section{Bibliography}

Architectural Forum. "Water Towers of Welded Steel.” May 1949, 129-130.

Becher, Hilla, and Bernd Becher. "Ammunition and Explosive Storage for the Navy (19391989) and the Air Becher.” Water Towers. Cambridge: The MIT Press, 1988.

Chattey, Paul. Historic Context: The Army's Military Mission at Fort Huachuca, Arizona 1877-1940. Seattle, WA: Center for Expertise for Preservation of Structures and Buildings of USACE, 2000.

Chicago Bridge \& Iron Works. Elevated Tank Designs Submitted in a Competition. Chicago: Chicago Bridge \& Iron Works, 1931.

Gray, W. S. Reinforced Concrete Water Towers, Bunkers, Silos, and Gantries. London: Concrete Publications Limited, 1947.

Hazlehurst, J. N. Towers and Tanks for Water-Works. New York: John Wiley \& Sons, 1904.

Headman, Ferguson \& Carollo Architects and Engineers. Completion Report, Cantonment Construction, Fort Huachuca, Arizona. Phoenix, AZ: Headman, Ferguson \& Carollo Architects and Engineers, May 10, 1941. (Accessed at NARA College Park RG77 Construction Completion Reports Fort Huachuca Vol. 4 Box 134).

Herbert, Rand F. 1990. Fort Huachuca, Arizona: A Century of Development and Changing Missions 1877-1977. Davis, CA: Jackson Research Projects.

Loechl, Suzanne K., Susan I. Enscore, Megan Weaver Tooker, and Samuel A. Batzli. Guidelines for Identifying and Evaluating Historic Military Landscapes. Technical Report ERDC/CERL TR-09-6. Champaign, IL: Engineer Research and Development Center, Construction Engineering Research Laboratory (ERDCCERL), 2009.

National Park Service. National Register Bulletin \#15: How to Apply the National Register Criteria for Evaluation. Washington, DC: U.S. Department of the Interior, National Park Service, 1997. Available online: https://www.nps.gov/nr/publications/bulletins/nrb15/.

Spreng, Ronald E. "They Didn't Just Grow There - Building Water Towers in the Postwar Era." Minnesota History, Winter 1992.

Tomes, Angel. 2013. Architectural Survey, Documentation, and Evaluation of 110 Buildings and Structures at Fort Huachuca, Arizona. Tucson, AZ: Statistical Research, Inc.

Tomes, Angel, and Scott Thompson. 2014. Inventory, Documentation, and Evaluation of 30 Buildings and Structures, 194 Works Progress Administration (WPA) Features, and Identification of a Potential WPA Historic District at Fort Huachuca, Arizona. Tucson, AZ: Statistical Research, Inc. 
Valenzuela, S. Elizabeth. 2011. FY12 SRM Facilities and Demolition Projects: Documentation and National Register Evaluation of 29 Buildings on Fort Huachuca, Arizona. Austin, TX: Valenzuela Preservation Studio.

Vanderpot, Rein, ed. 2012. Condition Assessment of 53 Sites and Development of a Monitoring and Site Protection Plan for Threatened Sites on the East Range, Fort Huachuca, Arizona. Fort Huachuca Cultural Resources Report FH-12-8. Tucson, AZ: Statistical Research Inc.

Wee, Stephen R., and Stephen D. Mikesell. National Register of Historic Places Registration, Form for Fort Huachuca Historic District. Washington, D.C.: National Register of Historic Places, National Park Service, U.S. Department of the Interior, 1993.

\section{Archival Sources}

Records on file at the Fort Huachuca DPW office.

Records on file at the Fort Huachuca Museum Collection.

Records on file at the Fort Huachuca Real Property office.

Records on file at the National Archives at College Park, Maryland.

Records on file at the National Archives at Riverside, California. 


\section{Appendix: Fort Huachuca Historic Property Inventory Forms}

\begin{tabular}{|c|c|c|c|c|}
\hline \multicolumn{5}{|c|}{$\begin{array}{c}\text { FORT HUACHUCA } \\
\text { HISTORIC PROPERTY INVENTORY FORM }\end{array}$} \\
\hline $\begin{array}{l}\text { PROPERTY } \\
\text { BOUNDARIES } \\
\text { Smith Avenue on the north, } \\
\text { Cushing Street on the east, } \\
\text { Railroad Avenue North on } \\
\text { the south, and recreational } \\
\text { facilities to the west. }\end{array}$ & \multicolumn{3}{|c|}{$\begin{array}{l}\text { COMMON/HISTORIC NAME } \\
\text { Fort Huachuca elevated water tank (Facility 49001) } \\
\text { Elevated water tank (Facility 8165) }\end{array}$} & $\frac{\text { STATUS }}{\text { Usable }}$ \\
\hline $\begin{array}{l}\text { ARCHITECT/BUILDER } \\
\text { Allison Steel Manufacturing } \\
\text { Company }\end{array}$ & \multicolumn{2}{|c|}{$\frac{\text { DATE OF CONSTRUCTION }}{\frac{\text { DATE OF ALTERATIONS }}{1941}}$} & $\frac{\underline{\text { NO. OF }}}{\text { STORIES }}$ & $\frac{\text { FOOTPRINT }}{\text { NA }}$ \\
\hline ROOF FORM & \multicolumn{2}{|l|}{$\frac{\text { FOUNDATION }}{\text { Concrete }}$} & $\frac{\text { WALLS }}{\text { Steel }}$ & $\frac{\text { ROOF }}{\text { Steel }}$ \\
\hline \multicolumn{3}{|c|}{ PROPERTY FUNCTION } & \multirow{3}{*}{\multicolumn{2}{|c|}{$\begin{array}{l}\text { NOTABLE FEATURES } \\
\text { None }\end{array}$}} \\
\hline Elevated water tank & & Elevated water tank & & \\
\hline \multicolumn{3}{|c|}{$\begin{array}{l}\text { RELATIONSHIP TO OTHER BUILDINGS } \\
\text { None }\end{array}$} & & \\
\hline
\end{tabular}




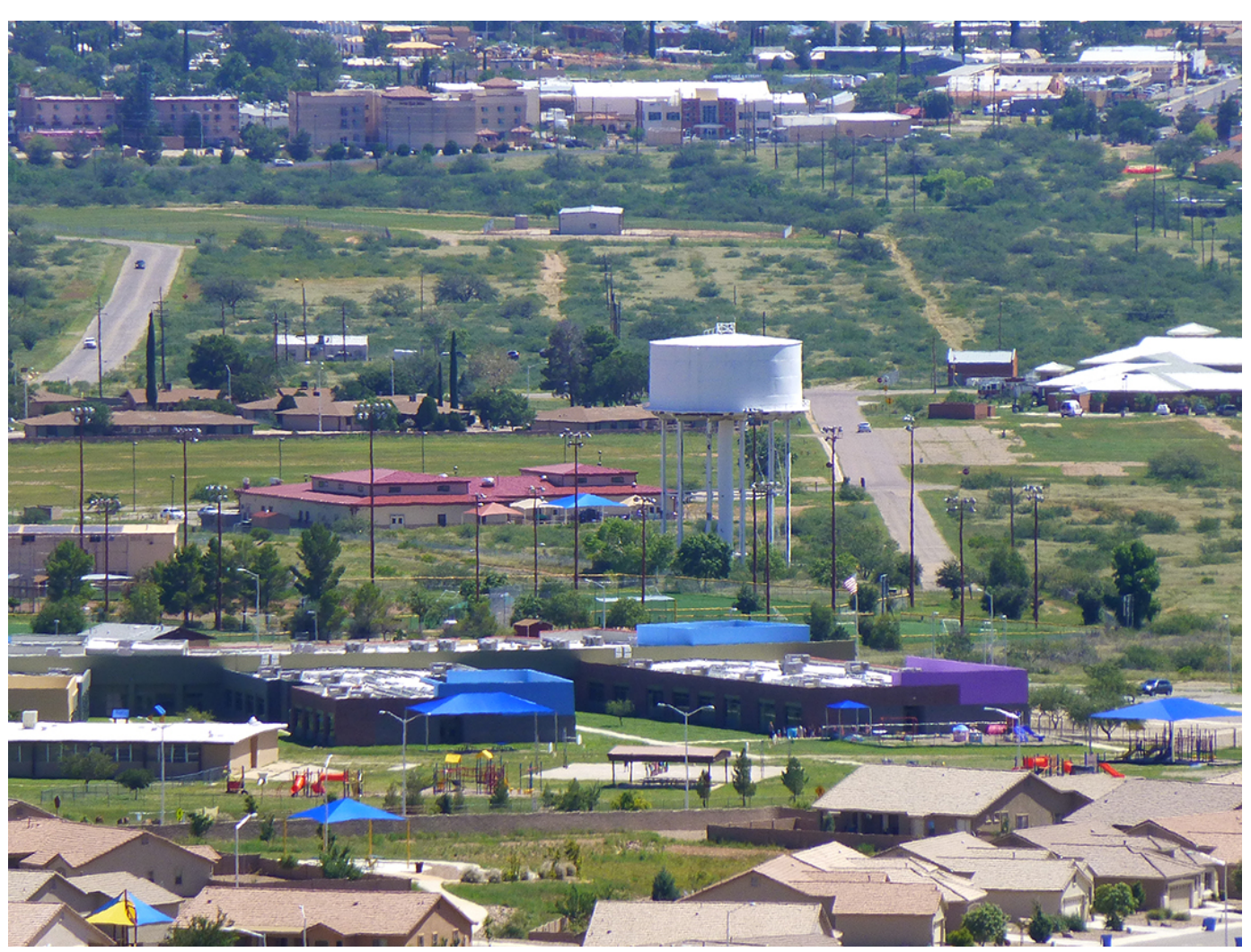

Photo 1. Overview of the Fort Huachuca elevated water tank (Facility 49001), looking east (ERDCCERL, 2015).

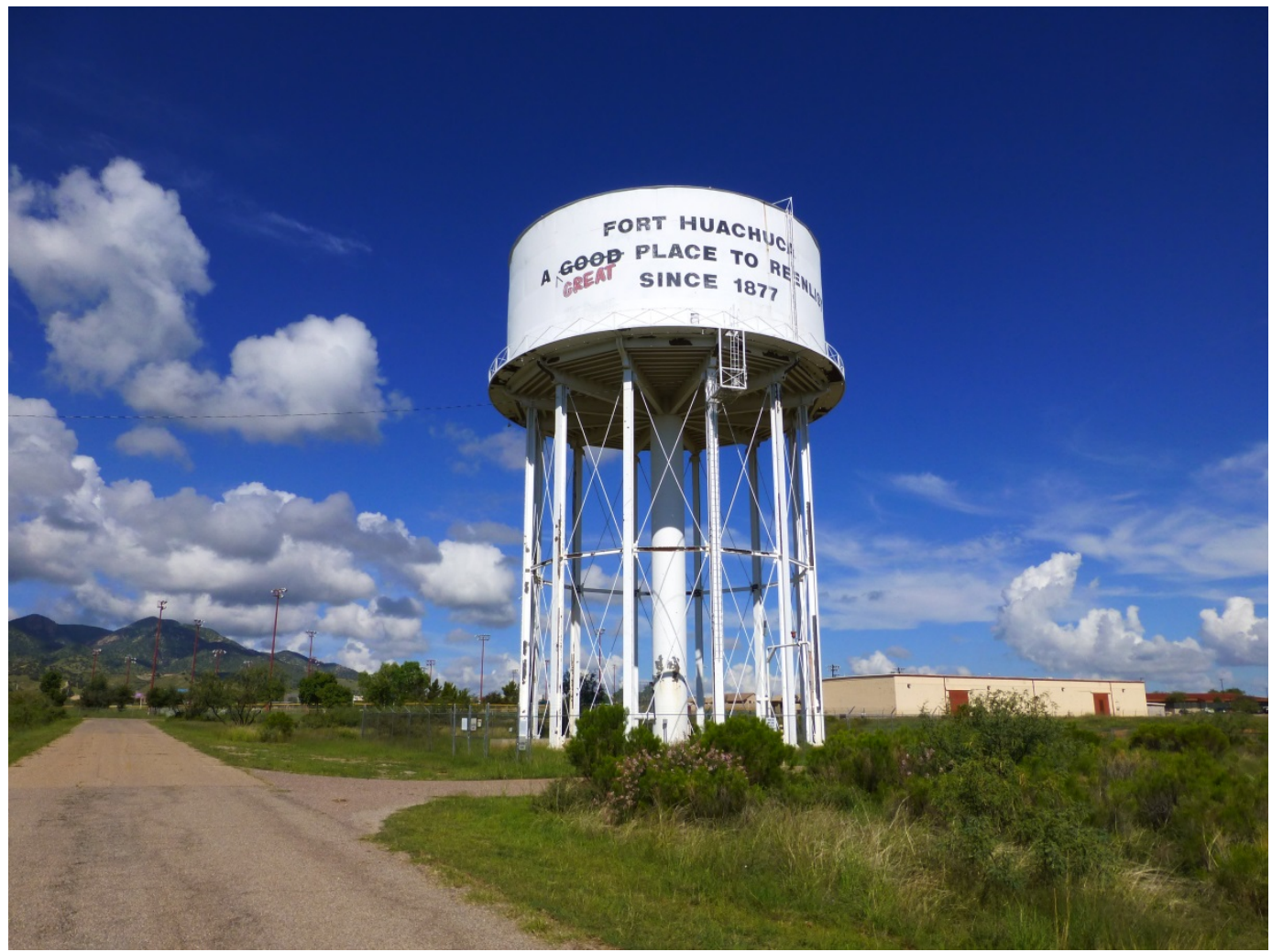

Photo 2. Fort Huachuca elevated water tank (Facility 49001), looking west (ERDC-CERL, 2015). 


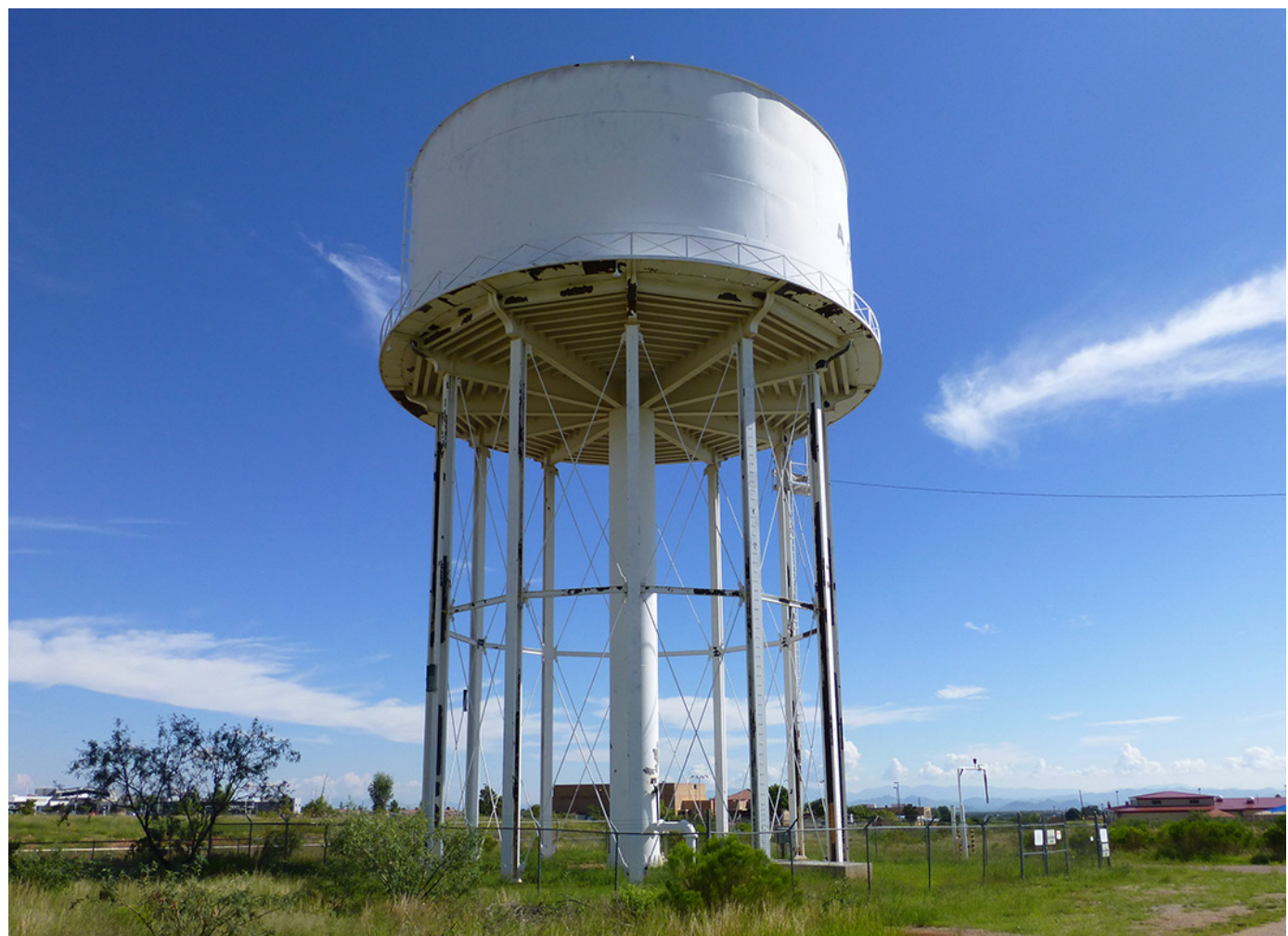

Photo 3. Close-up of Fort Huachuca elevated water tank (Facility 49001), looking east (ERDC-CERL, 2015).

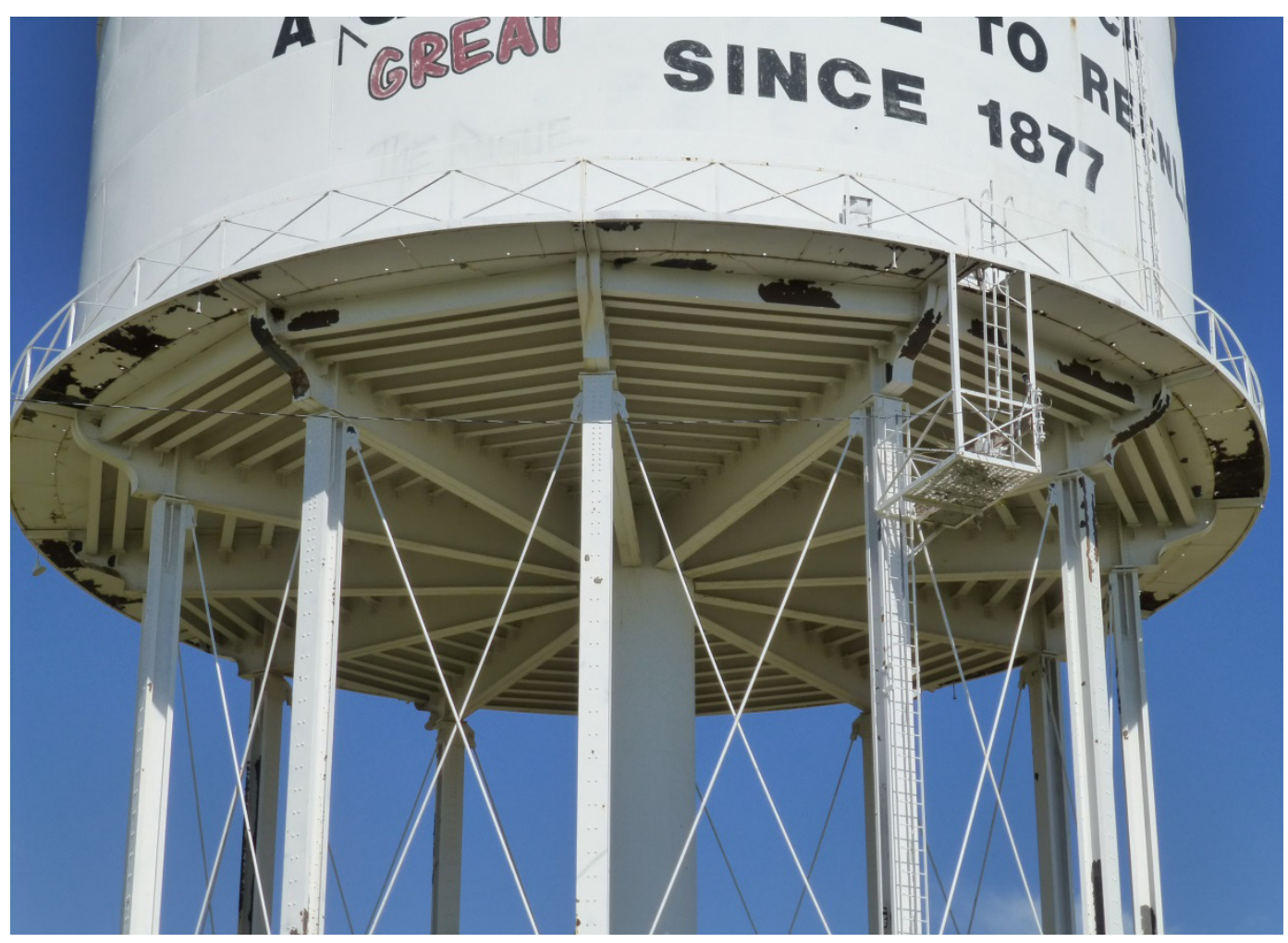

Photo 4. Underside of Fort Huachuca elevated water tank (Facility 49001), looking east (ERDC-CERL, 2015). 


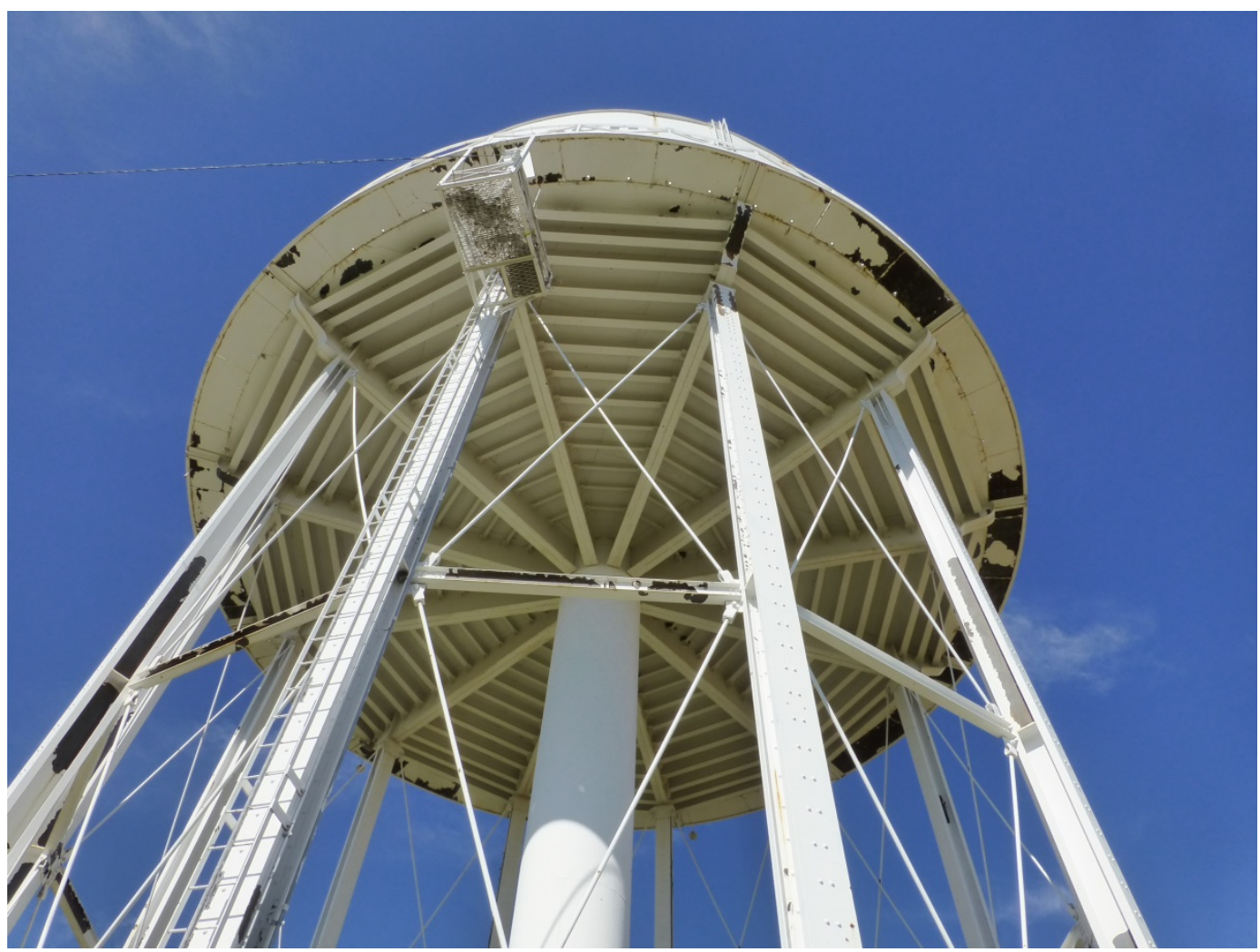

Photo 5. Underside of the Fort Huachuca elevated water tank (Facility 49001) (ERDC-CERL, 2015).

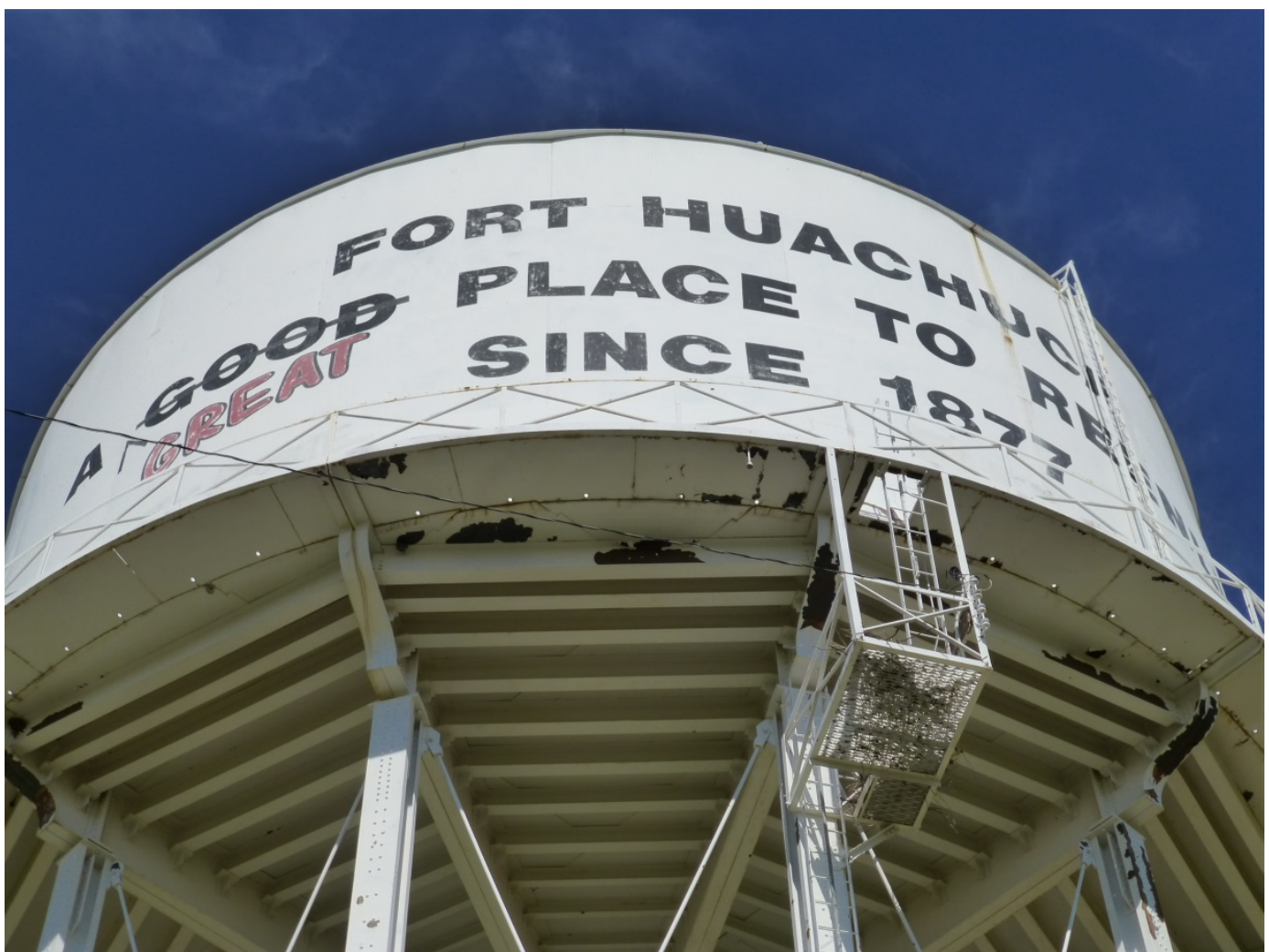

Photo 6. Fort Huachuca elevated water tank (Facility 49001) bottom edge, looking west (ERDC-CERL, 2015). 


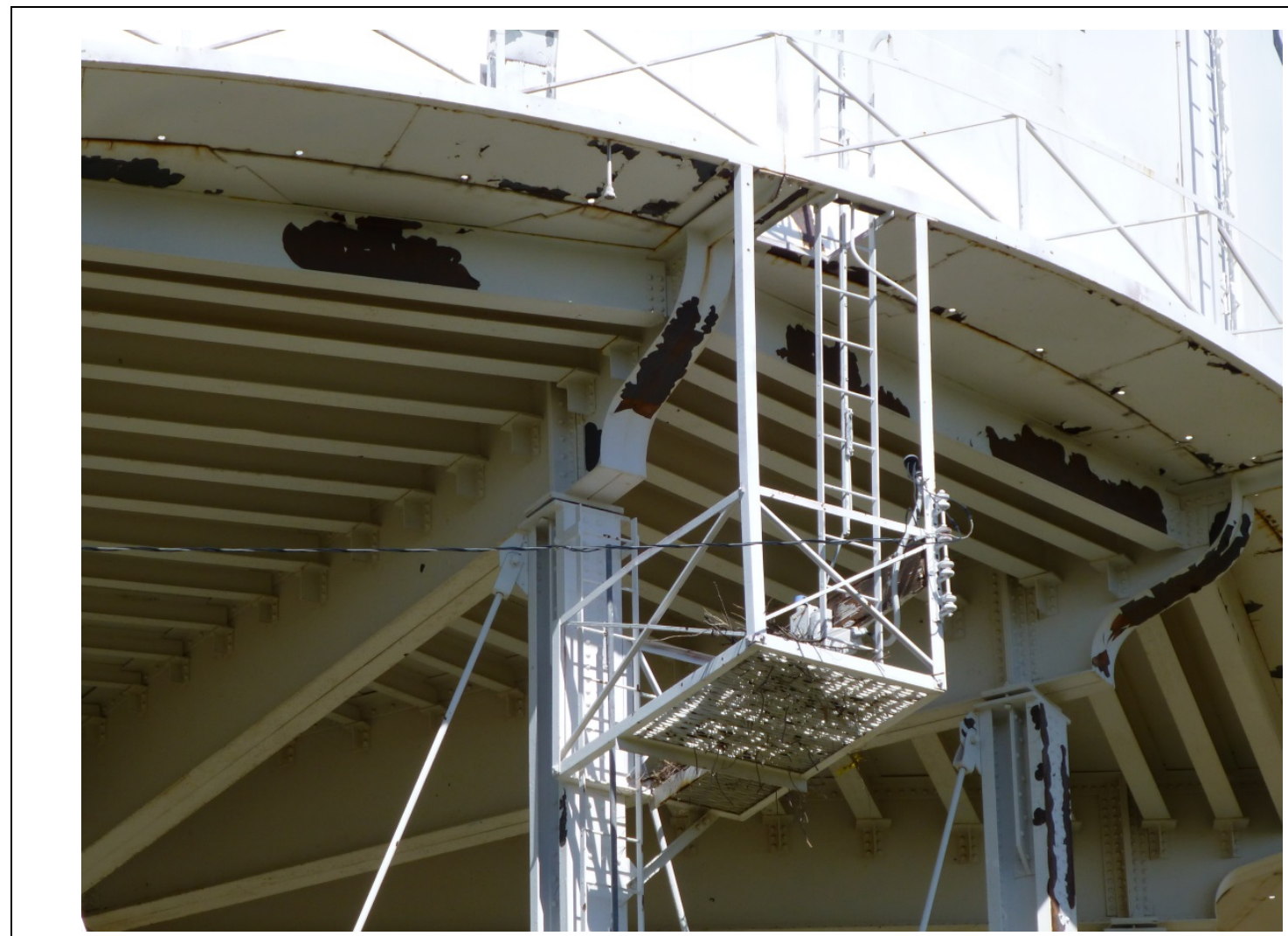

Photo 7. Fort Huachuca elevated water tank (Facility 49001), bottom edge detail (ERDC-CERL, 2015).

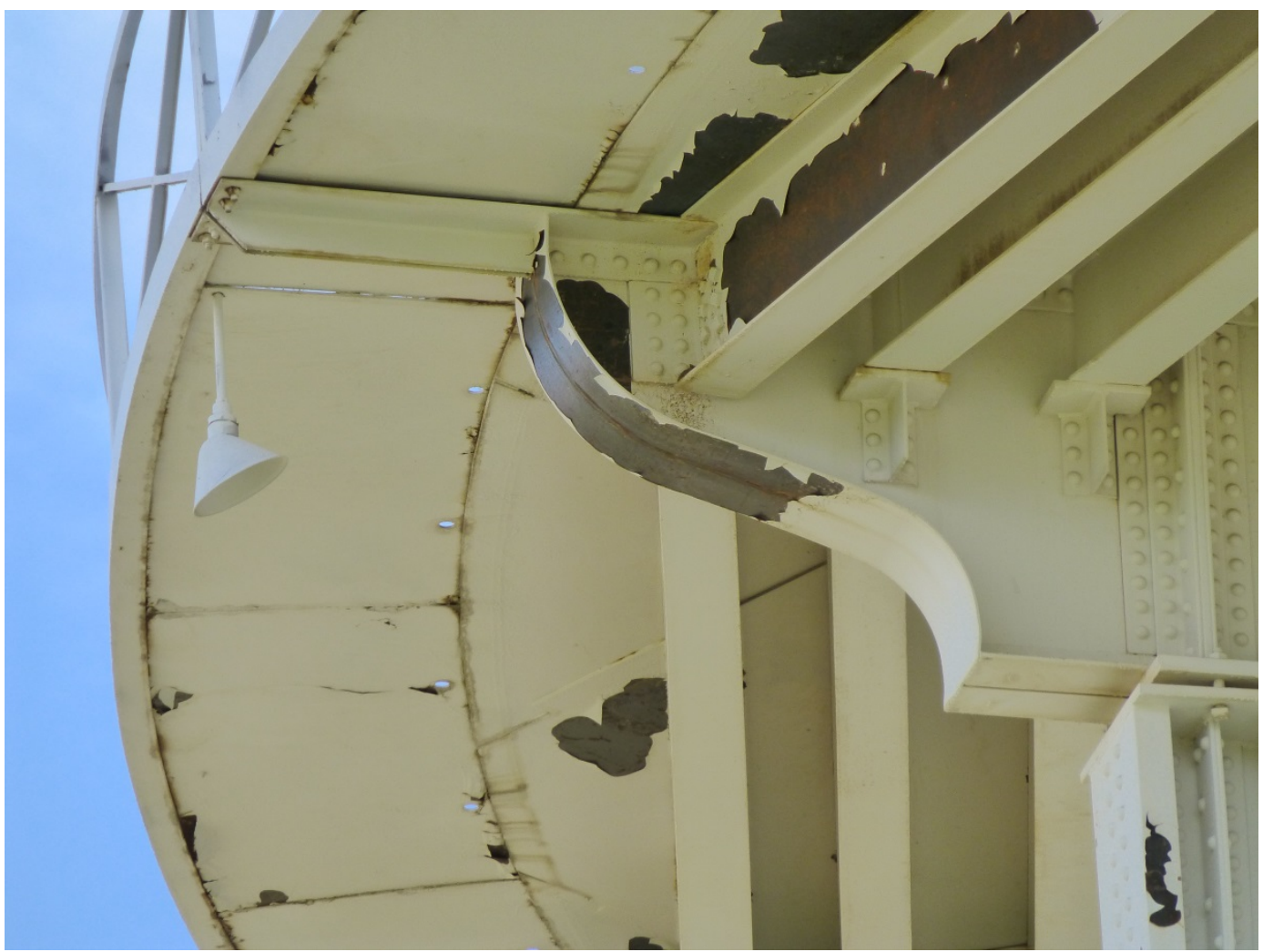

Photo 8. Fort Huachuca elevated water tank (Facility 49001), with detail of bracket at the end of a structural beam (ERDC-CERL, 2015). 


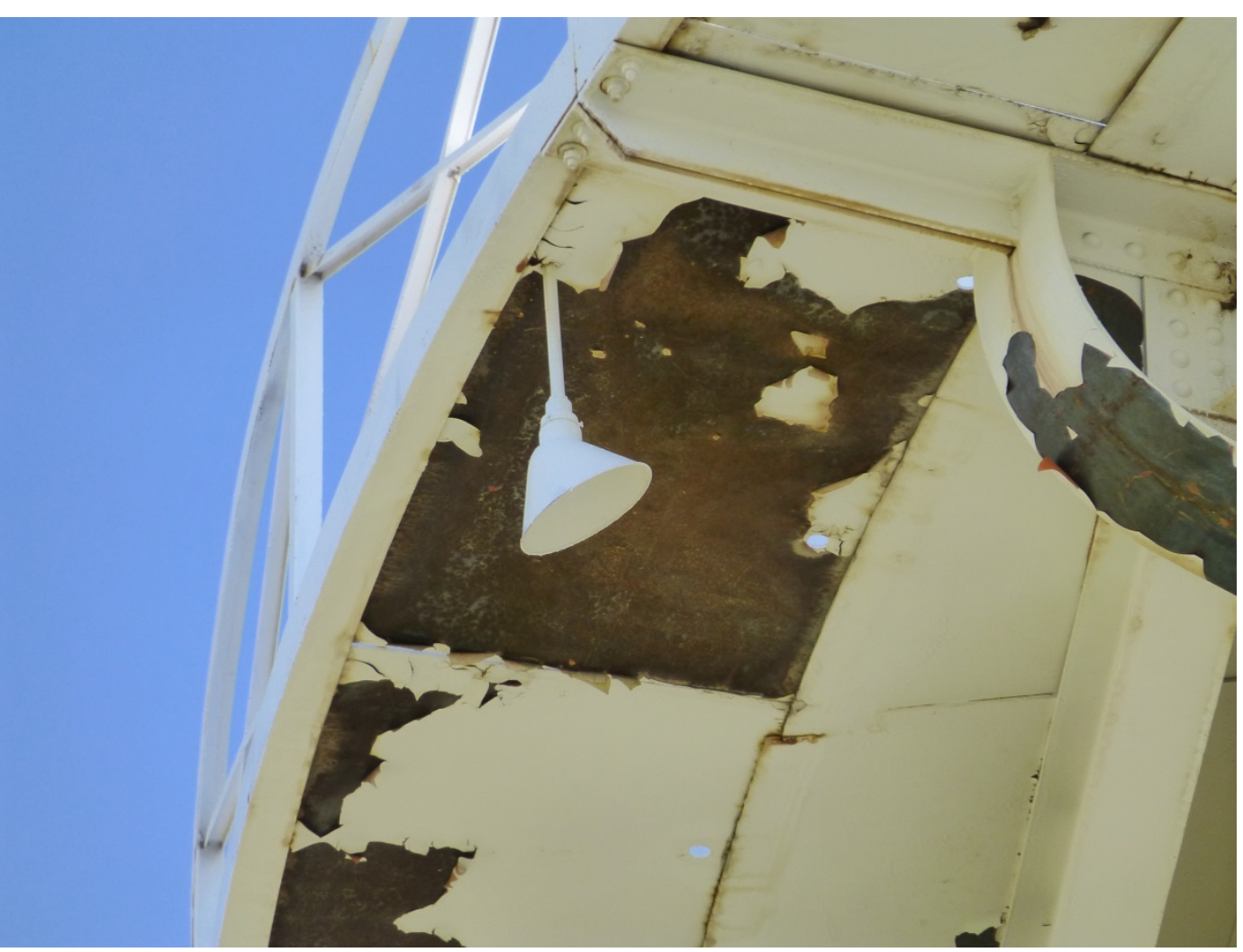

Photo 9. Detail of light fixture underneath the walkway surrounding the Fort Huachuca elevated water tank (Facility 49001) (ERDC-CERL, 2015).

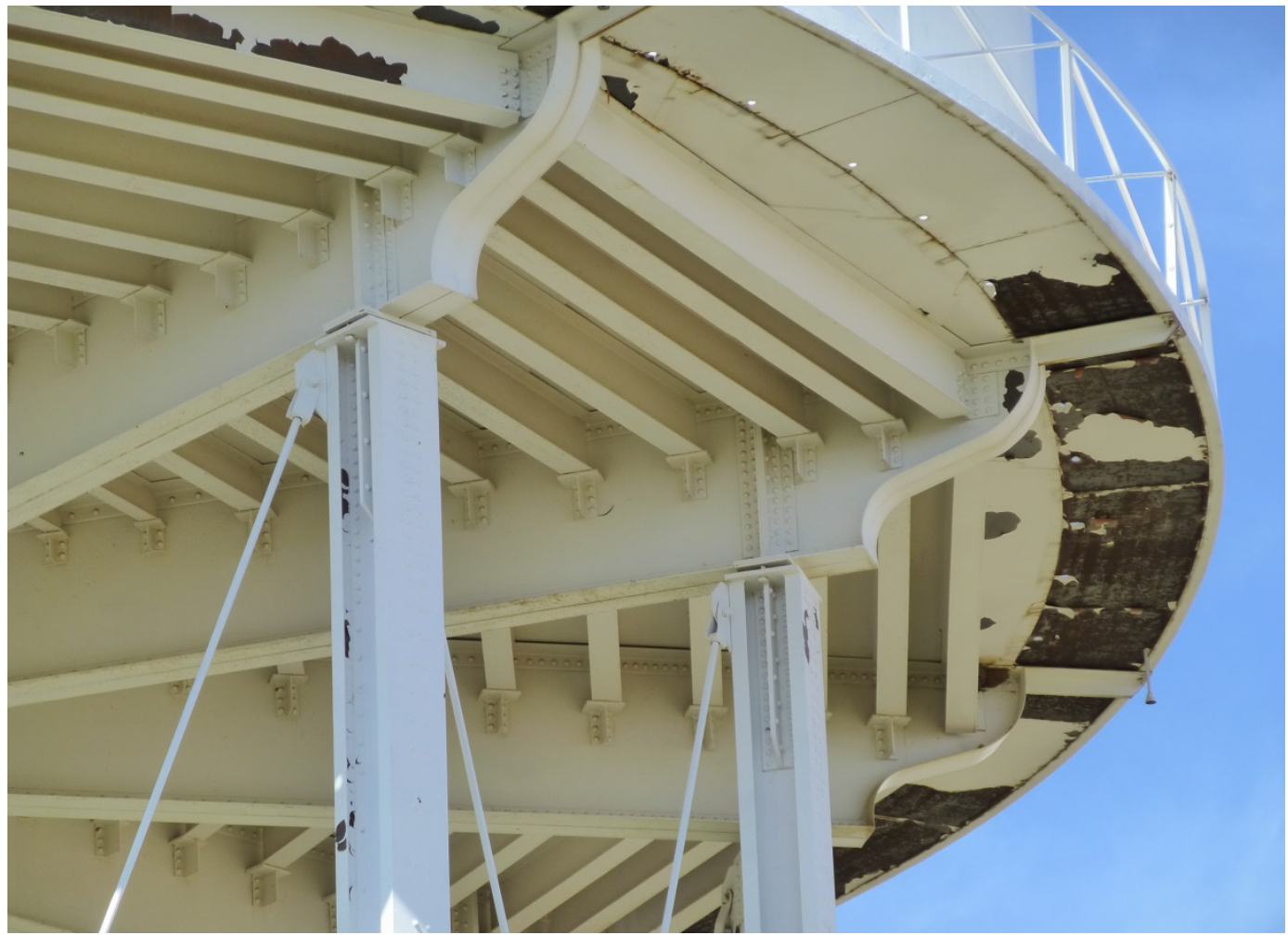

Photo 10. Detail of underside of Fort Huachuca elevated water tank (Facility 49001) (ERDC-CERL, 2015). 


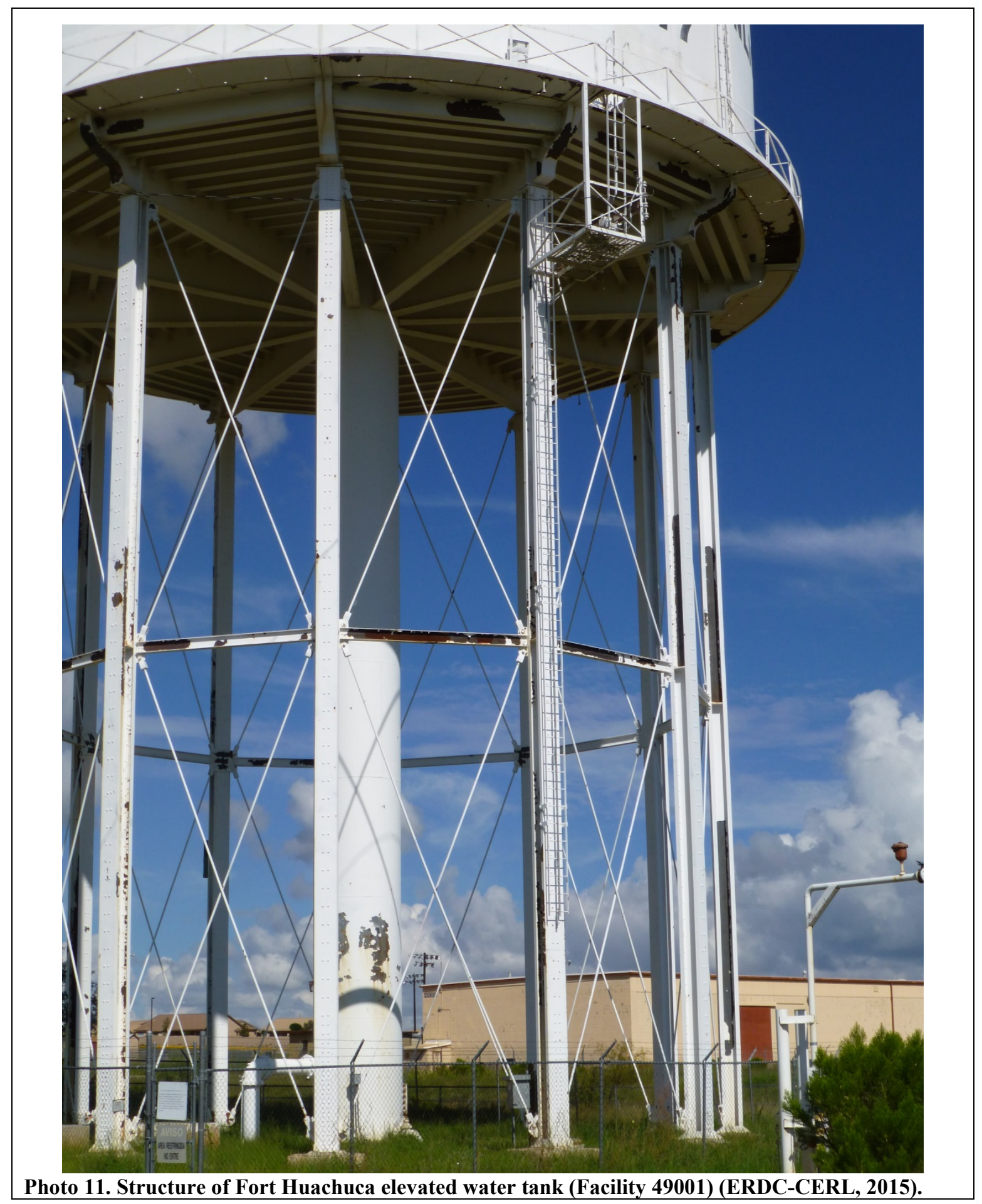




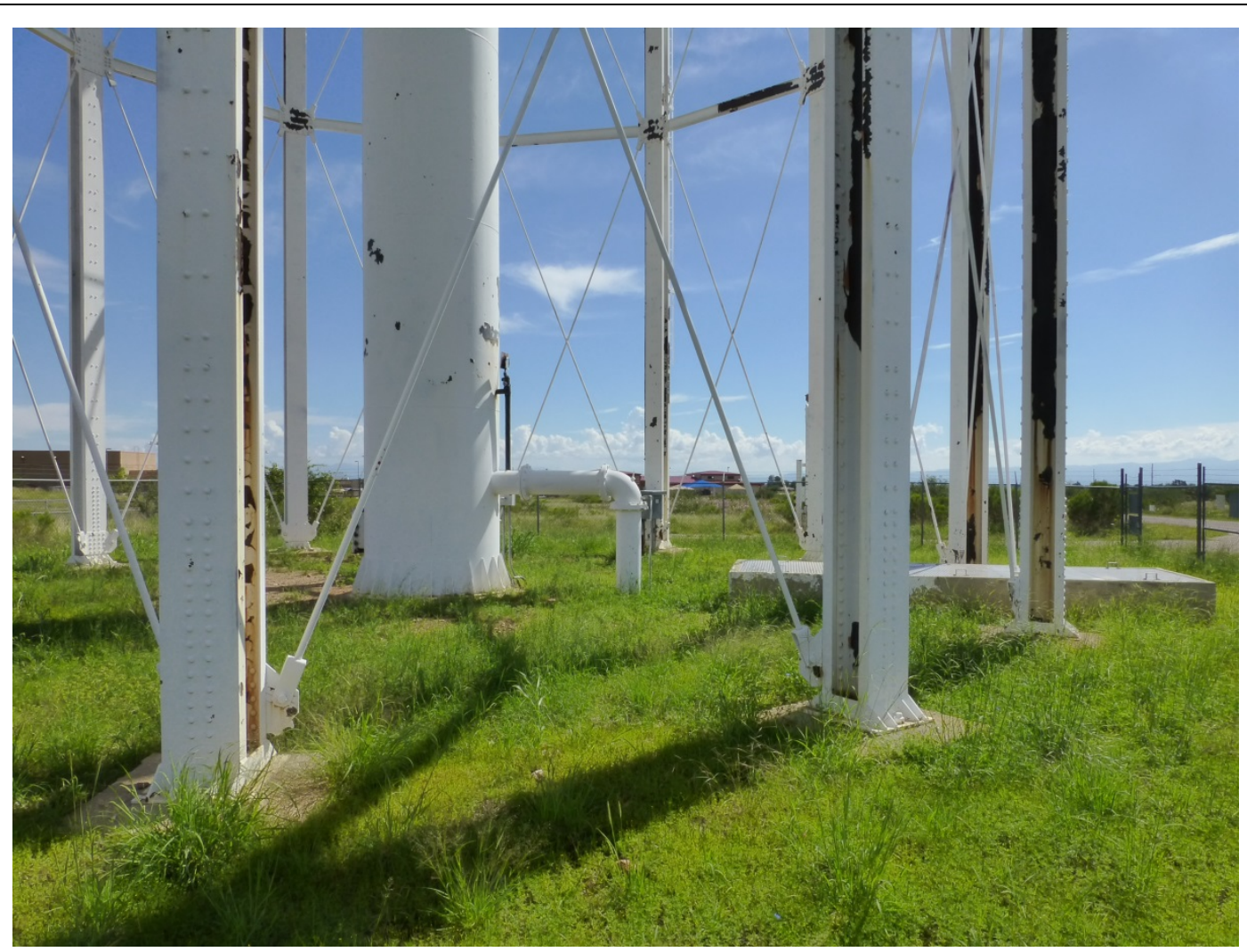

Photo 12. Base of structure and main pipe of Fort Huachuca elevated water tank (Facility 49001) (ERDC-CERL, 2015).

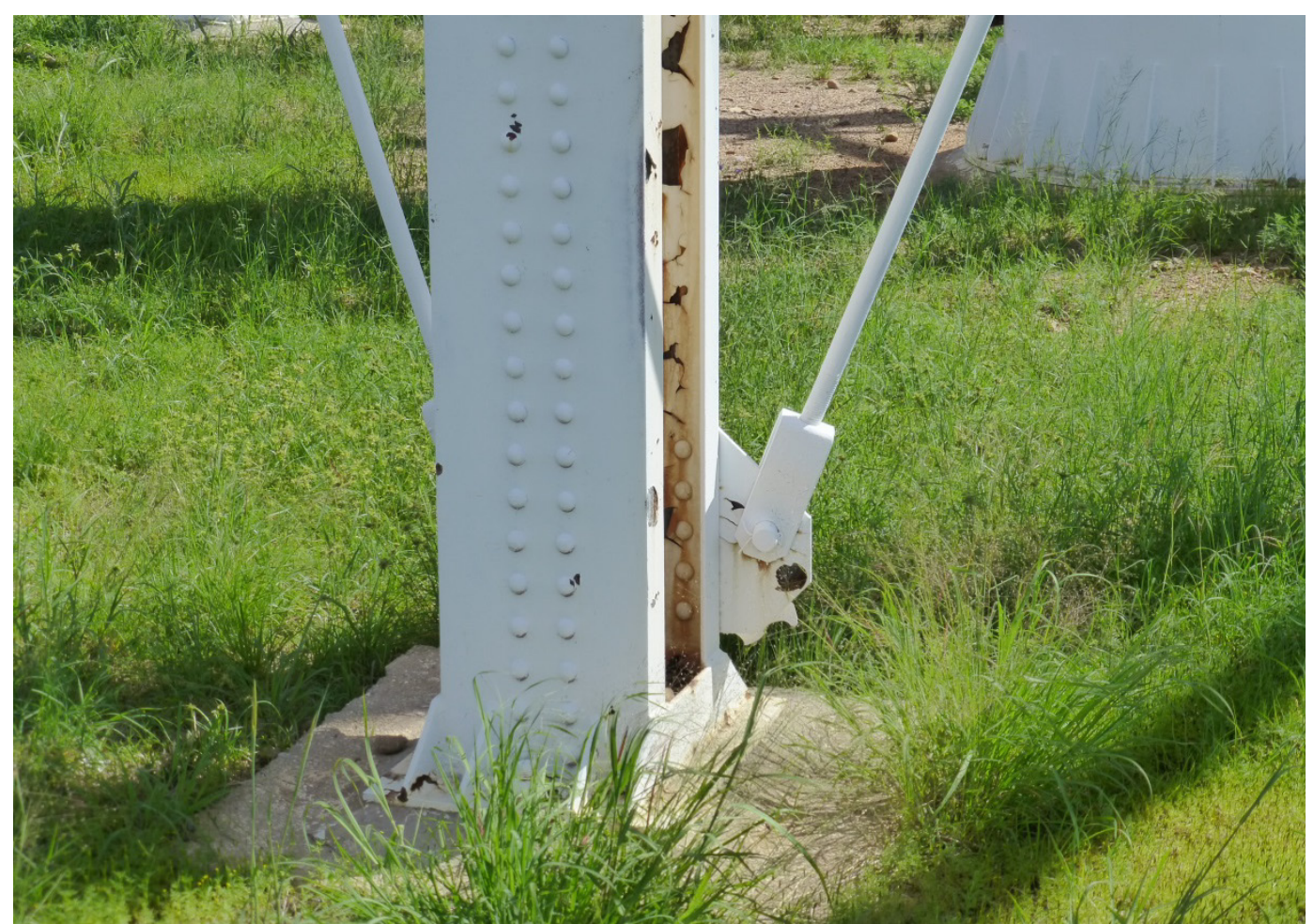

Photo 13. Close-up of structural column and foundation at the Fort Huachuca elevated water tank (Facility 49001) (ERDC-CERL, 2015). 


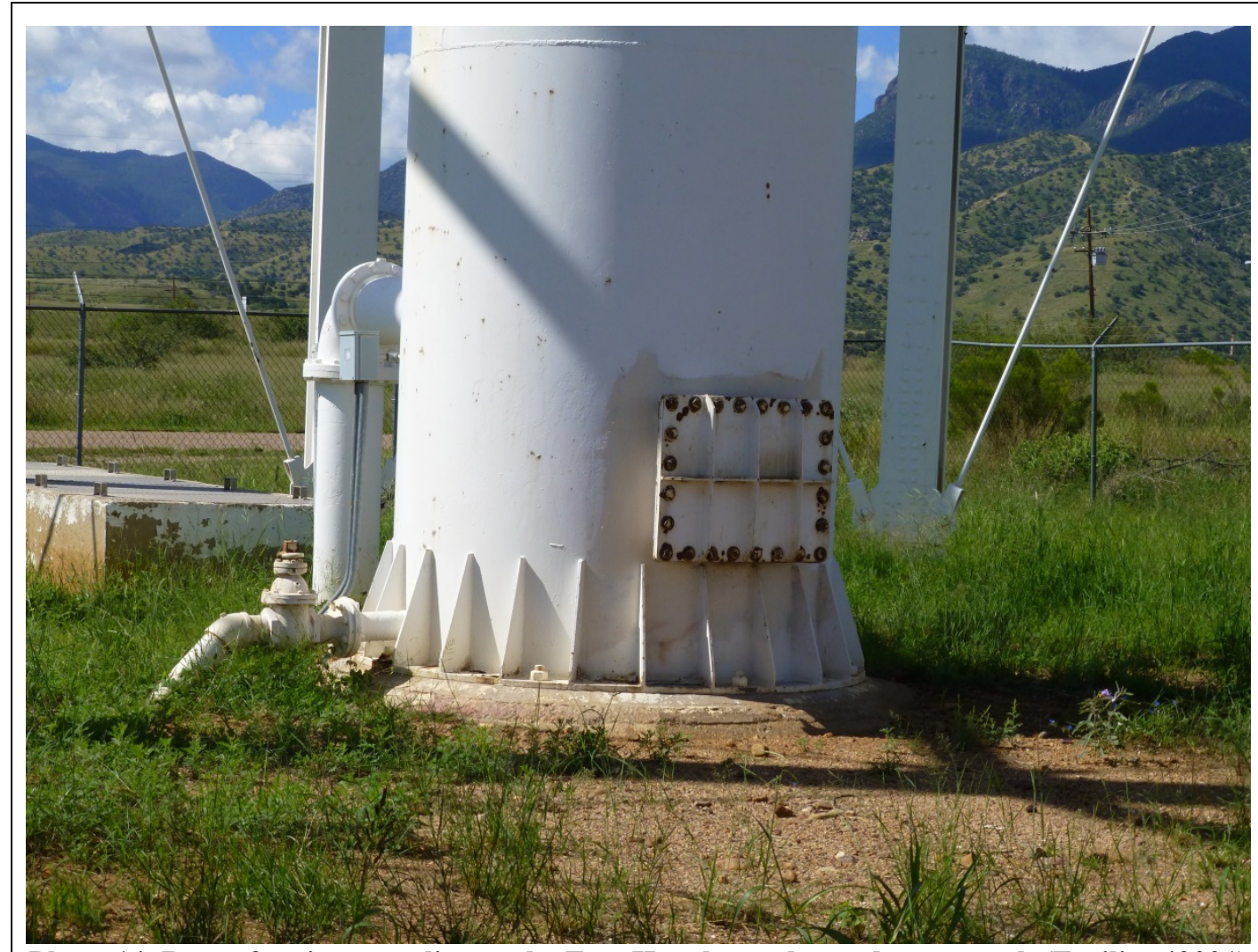

Photo 14. Base of main water line to the Fort Huachuca elevated water tank (Facility 49001) (ERDC-CERL, 2015).

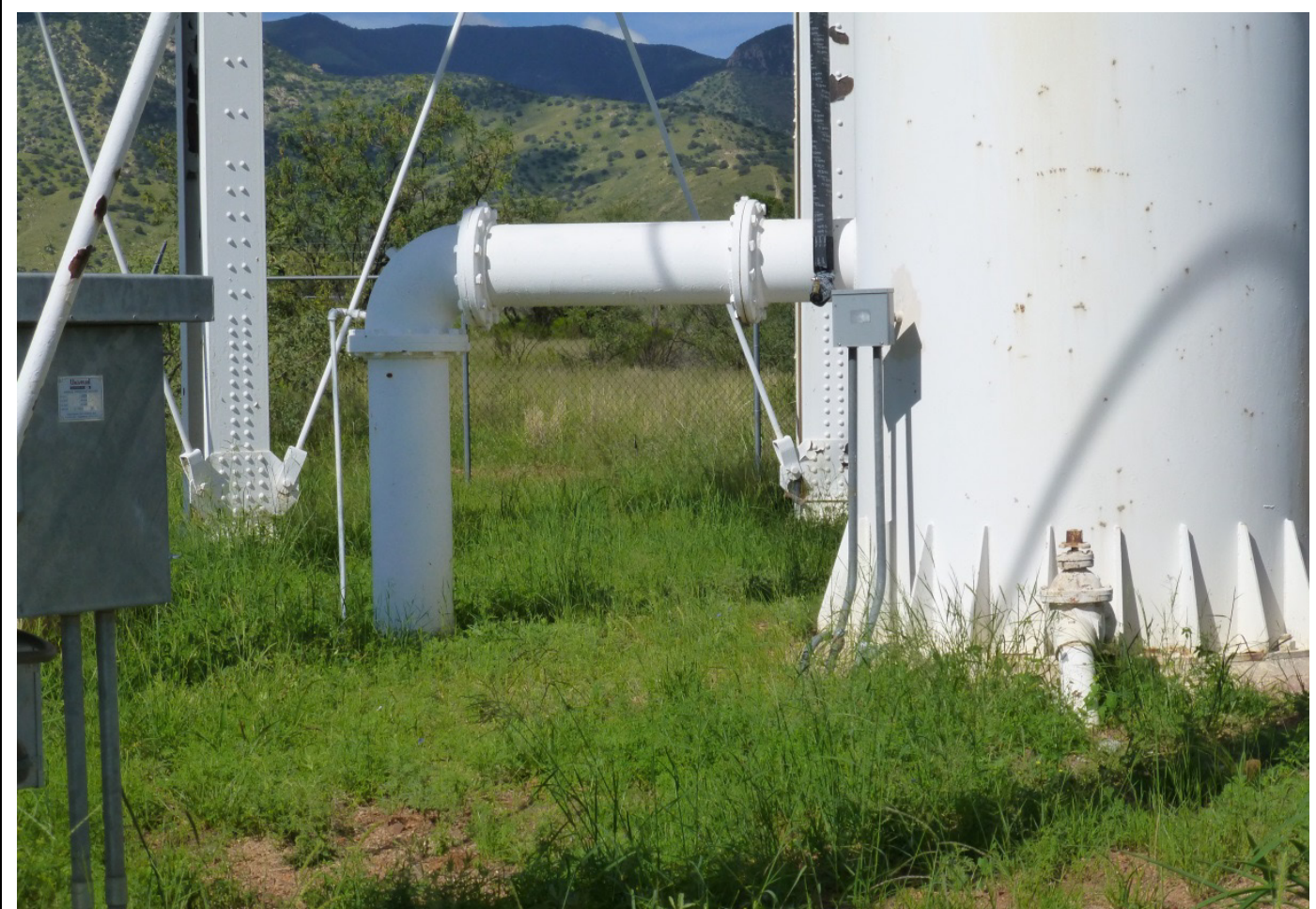

Photo 15. Base of main water line to the Fort Huachuca elevated water tank (Facility 49001) (ERDC-CERL, 2015). 


\begin{tabular}{|l|l|}
\hline COORDINATES & $\underline{\text { USGS QUAD }}$ \\
\hline UTM 12 & Fort Huachuca \\
$3490755.7 \mathrm{~N}$ & \\
\hline $562841.9 \mathrm{E}$ & \\
\hline
\end{tabular}

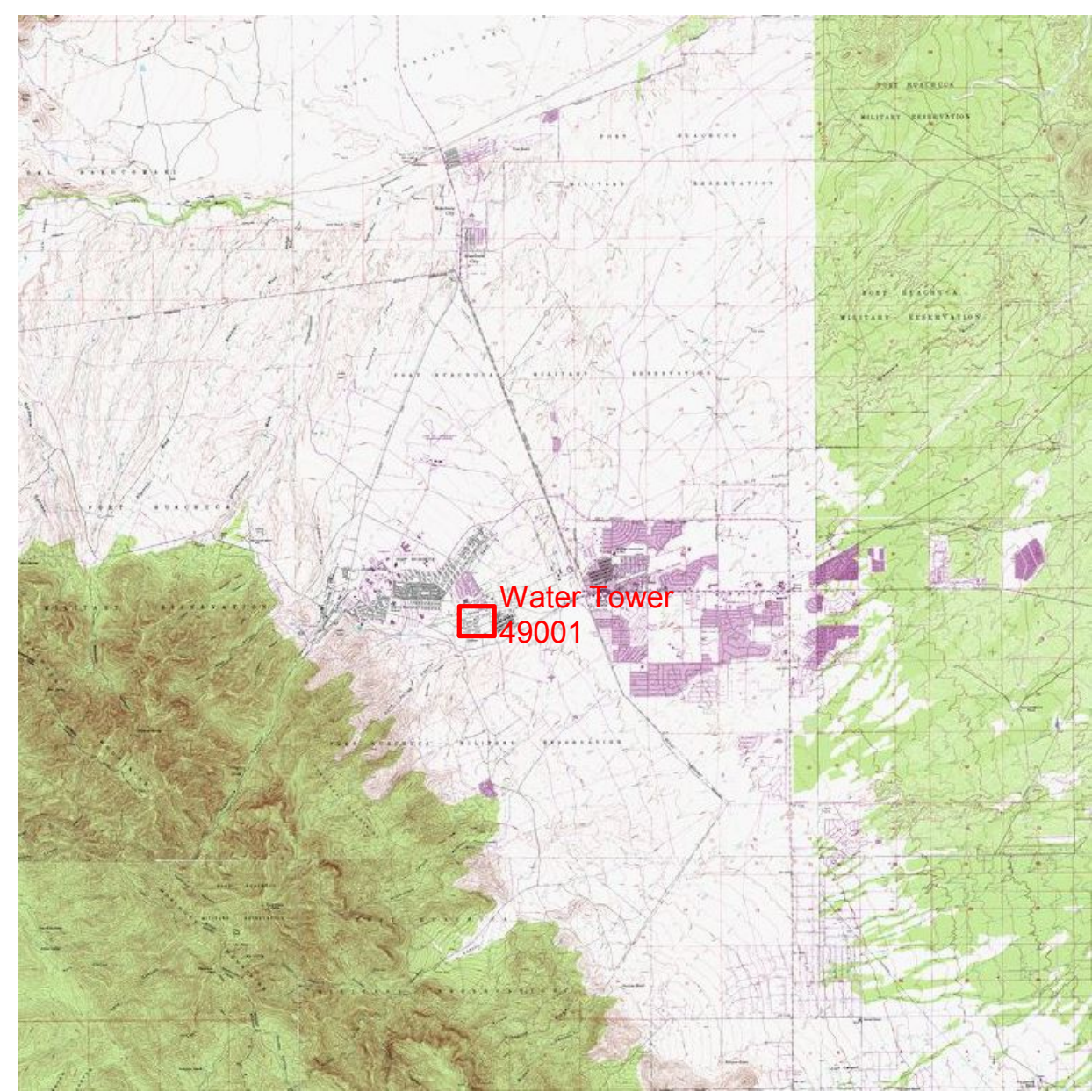

Fort Huachuca, Arizona Quad Map (courtesy U.S. Geological Survey [USGS]). 


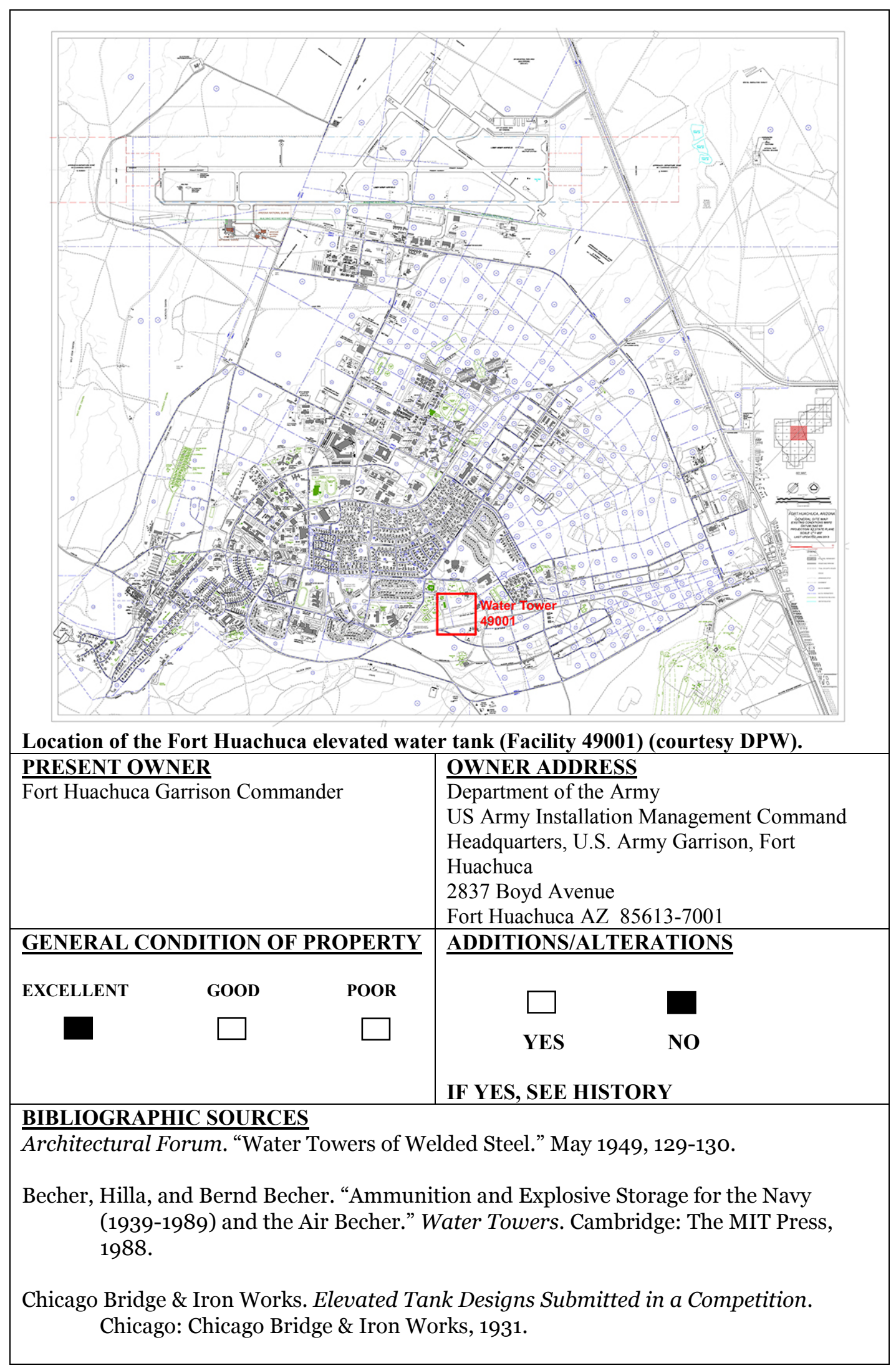


Gray, W. S. Reinforced Concrete Water Towers, Bunkers, Silos, and Gantries. London: Concrete Publications Limited, 1947.

Hazlehurst, J. N. Towers and Tanks for Water-Works. New York: John Wiley \& Sons, 1904.

Headman, Ferguson \& Carollo Architects and Engineers. Completion Report, Cantonment Construction, Fort Huachuca, Arizona. Phoenix, AZ: Headman, Ferguson \& Carollo Architects and Engineers, May 10, 1941. (Accessed at NARA College Park RG77 Construction Completion Reports Fort Huachuca Vol. 4 Box 134).

Herbert, Rand F. 1990. Fort Huachuca, Arizona: A Century of Development and Changing Missions 1877-1977. Davis, CA: Jackson Research Projects.

Loechl, Suzanne K., Susan I. Enscore, Megan Weaver Tooker, and Samuel A. Batzli. Guidelines for Identifying and Evaluating Historic Military Landscapes. Technical Report ERDC/CERL TR-09-6. Champaign, IL: Engineer Research and Development Center, Construction Engineering Research Laboratory (ERDCCERL), 2009.

Spreng, Ronald E. “They Didn’t Just Grow There - Building Water Towers in the Postwar Era.” Minnesota History, Winter 1992.

Tomes, Angel. 2013. Architectural Survey, Documentation, and Evaluation of 110 Buildings and Structures at Fort Huachuca, Arizona. Tucson, AZ: Statistical Research, Inc.

Tomes, Angel, and Scott Thompson. 2014. Inventory, Documentation, and Evaluation of 30 Buildings and Structures, 194 Works Progress Administration (WPA) Features, and Identification of a Potential WPA Historic District at Fort Huachuca, Arizona. Tucson, AZ: Statistical Research, Inc.

Valenzuela, S. Elizabeth. 2011. FY12 SRM Facilities and Demolition Projects: Documentation and National Register Evaluation of 29 Buildings on Fort Huachuca, Arizona. Austin, TX: Valenzuela Preservation Studio.

\section{ARCHIVAL SOURCES}

Records on file at the Fort Huachuca DPW office.

Records on file at the Fort Huachuca Museum Collection.

Records on file at the Fort Huachuca Real Property office.

Records on file at the National Archives at College Park, Maryland.

Records on file at the National Archives at Riverside, California. 


\begin{tabular}{|c|c|}
\hline $\begin{array}{l}\text { PRELIMINARY NATIONAL REGISTER } \\
\text { DETERMINATION OF ELIGIBILITY }\end{array}$ & $\begin{array}{l}\text { FORM PREPARED BY: } \\
\text { Courtney Wesa and Adam Smith } \\
\text { Engineer Research and Development Center } \\
\text { Construction Engineering Research Laboratory } \\
2902 \text { Newmark Drive } \\
\text { Champaign, IL } 61822\end{array}$ \\
\hline \multicolumn{2}{|c|}{$\begin{array}{l}\text { DESCRIPTION } \\
\text { Facility } 49001 \text { is a } 500,000 \text { gallon elevated water tank that is overall } 90 \text { feet tall with a } 29 \text { foot } \\
\text { high elevated water tank that is } 59 \text { feet wide. }\end{array}$} \\
\hline \multicolumn{2}{|c|}{ 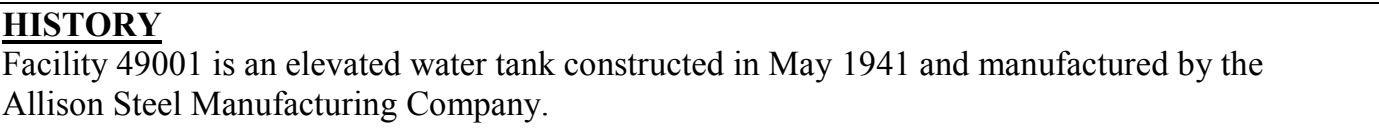 } \\
\hline \multicolumn{2}{|c|}{$\begin{array}{l}\text { SIGNIFICANCE } \\
\text { The elevated water tank, while part of the water supply of Fort Huachuca, is not significant to the } \\
\text { mission of Fort Huachuca, and it does not in and of itself have significance at the national, state, } \\
\text { or local level under any of the four Criteria for Evaluation. }\end{array}$} \\
\hline \multicolumn{2}{|l|}{ INTEGRITY } \\
\hline \multicolumn{2}{|c|}{$\begin{array}{l}\text { RECOMMENDATION OF CONTRIBUTING/NONCONTRIBUTING STATUS } \\
\text { It is the recommendation of this report that the elevated water tank (Facility 49001) erected in } \\
1941 \text { is individually NOT ELIGIBLE to the NRHP due to the lack of significance for } \\
\text { construction, engineering, or role under any of the four Criteria for Evaluation. The elevated water } \\
\text { tank is not significant to the mission of Fort Huachuca, and under Criterion A, it is not significant } \\
\text { to the Army at the national, state, or local levels. The design and engineering of the elevated water } \\
\text { tank is not attributed to a master engineer under Criterion C, and its design is typical of its era and } \\
\text { of the Allison Steel Manufacturing Company. The demolition of its twin (erected in } 1942 \text { and } \\
\text { demolished in 1974) and the demolition of all the surrounding WWII Army temporary buildings } \\
\text { has severely impacted the historic context of the elevated water tank. }\end{array}$} \\
\hline
\end{tabular}




\section{HISTORIC PHOTOGRAPHS}

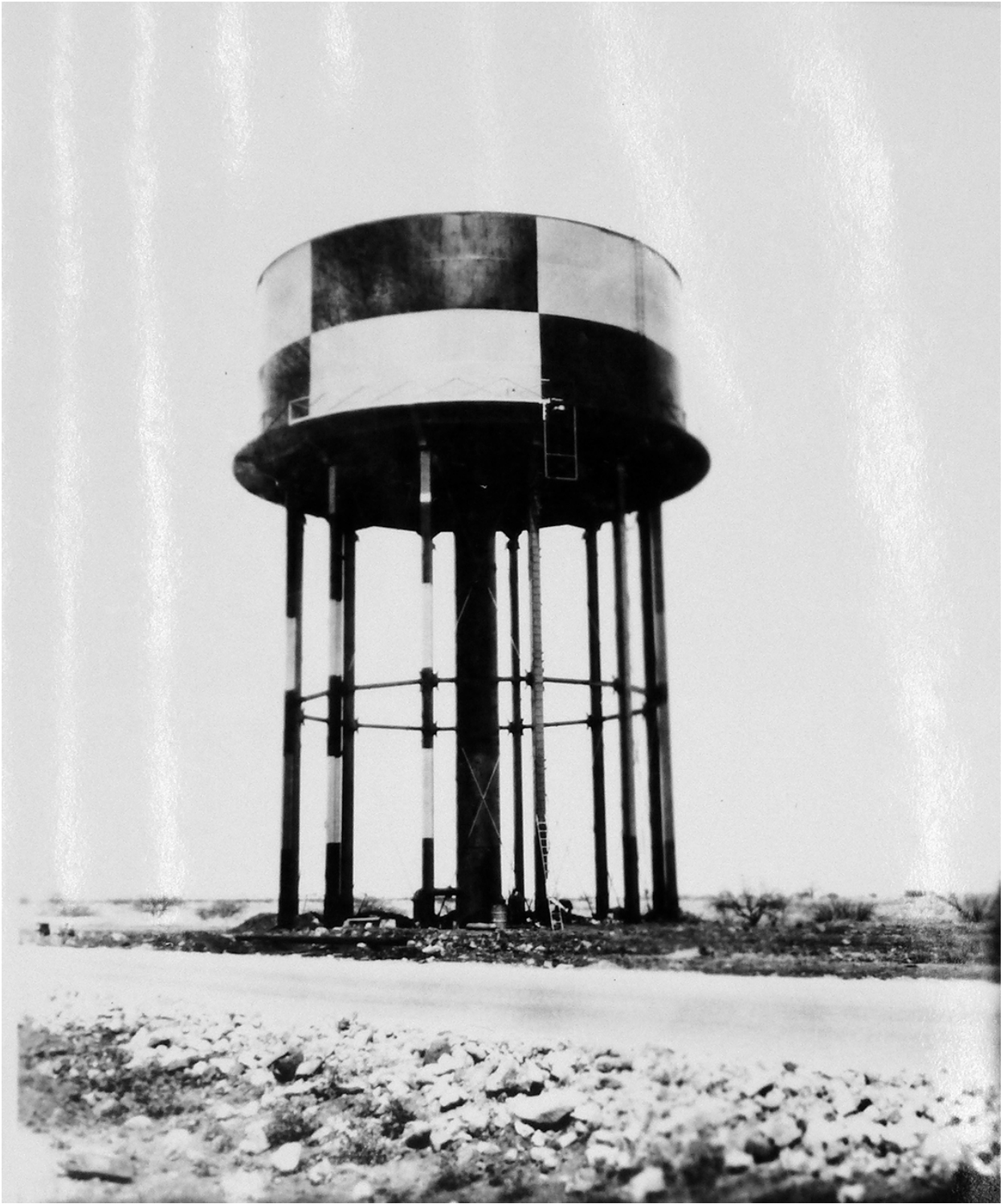

View of the elevated water tank, May 1, 1941 (NARA College Park RG77-133). 


\begin{tabular}{|c|c|c|c|}
\hline \multicolumn{4}{|c|}{$\begin{array}{c}\text { FORT HUACHUCA } \\
\text { HISTORIC PROPERTY INVENTORY FORM }\end{array}$} \\
\hline $\begin{array}{l}\text { PROPERTY } \\
\text { BOUNDARIES } \\
\text { Alley on the northeast and } \\
\text { northwest, and hillside on } \\
\text { the southwest and southeast }\end{array}$ & \multicolumn{2}{|c|}{$\frac{\text { COMMON/HISTORIC NAME }}{\text { Fort Huachuca 1,500,000 reservoir (Facility 22020) }}$} & $\frac{\text { STATUS }}{\text { Usable }}$ \\
\hline$\frac{\text { ARCHITECT/BUILDER }}{\text { Unknown }}$ & $\begin{array}{l}\text { DATE OF CONSTRUCTION } \\
1959 \\
\underline{\text { DATE OF ALTERATIONS }}\end{array}$ & $\frac{\underline{\text { NO. OF }}}{\underline{\text { STORIES }}}$ & FOOTPRINT \\
\hline$\frac{\text { ROOF FORM }}{\text { Dome }}$ & $\frac{\text { FOUNDATION }}{\text { Concrete }}$ & $\frac{\text { WALLS }}{\text { Concrete }}$ & $\underline{\text { ROOF }}$ \\
\hline \multicolumn{2}{|c|}{ PROPERTY FUNCTION } & \multirow{2}{*}{\multicolumn{2}{|c|}{$\begin{array}{l}\text { NOTABLE FEATURES } \\
\text { None }\end{array}$}} \\
\hline Water reservoir & Water reservoir & & \\
\hline \multicolumn{2}{|c|}{$\begin{array}{l}\text { RELATIONSHIP TO OTHER BUILDINGS } \\
\text { None }\end{array}$} & & \\
\hline
\end{tabular}




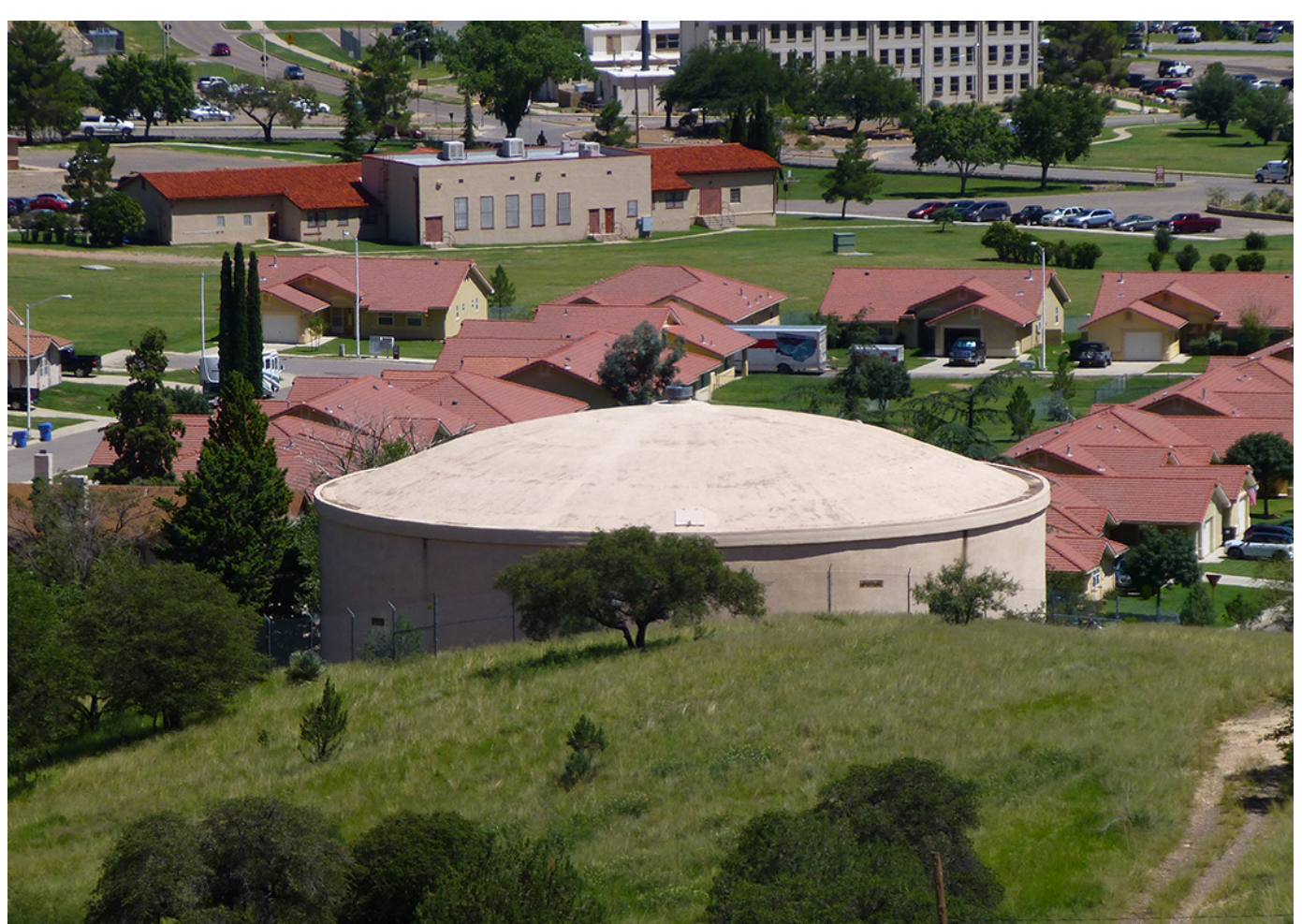

Photo 1. Overview of the 1,500,000 gallon water reservoir (Facility 22020), looking east (ERDC-CERL, 2015).

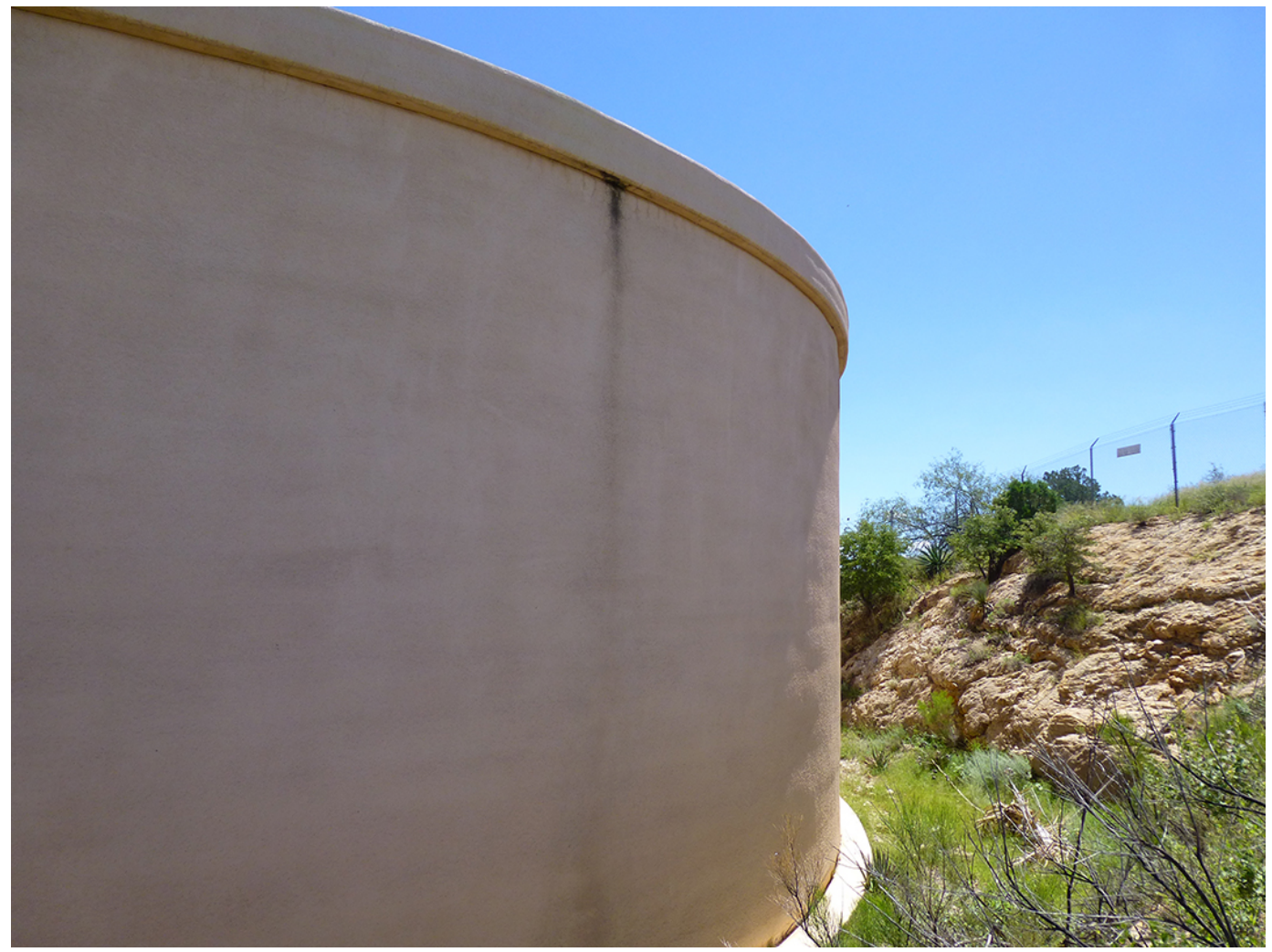

Photo 2. Side view of the 1,500,000 gallon water reservoir (Facility 22020), looking southwest (ERDCCERL, 2015). 


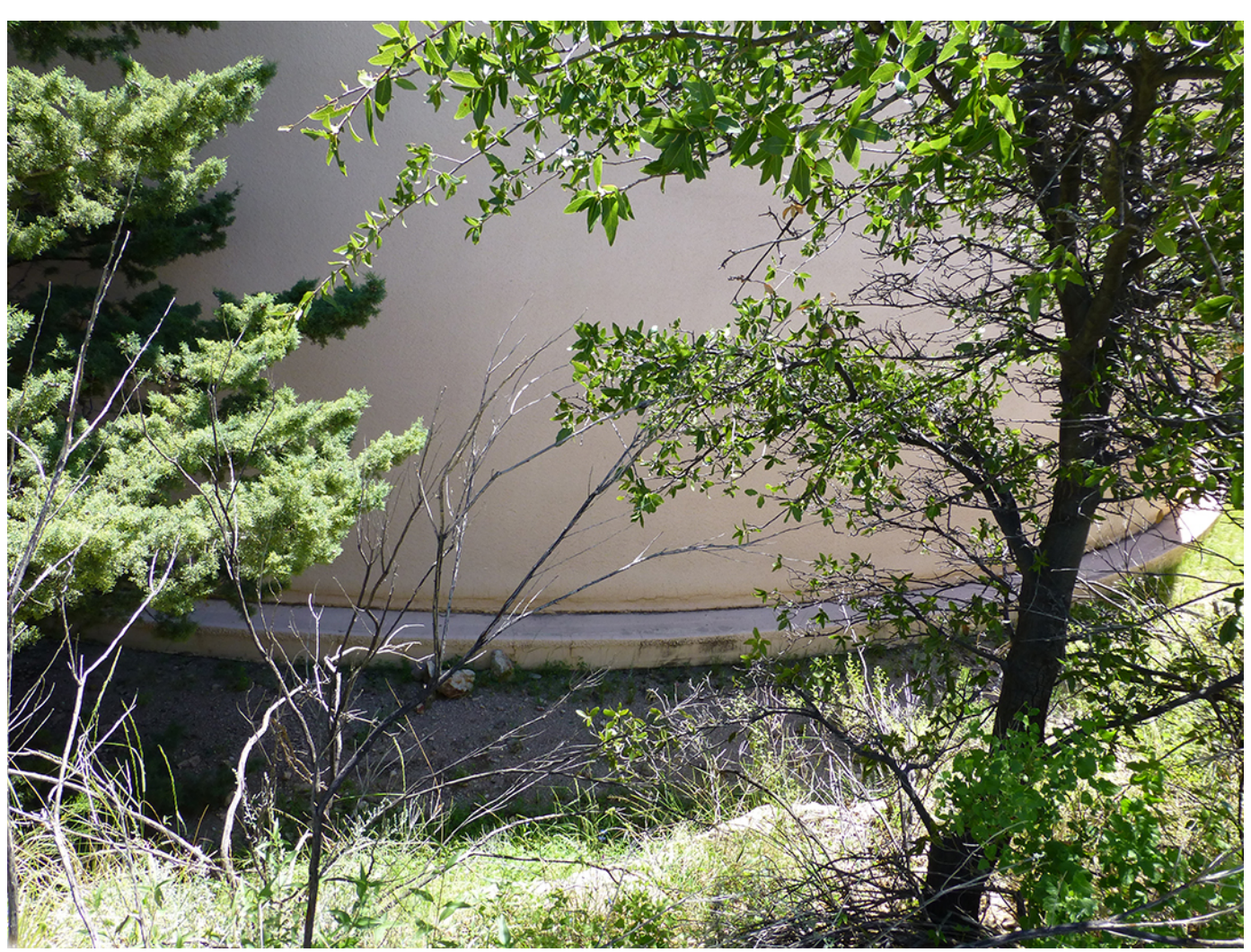

Photo 3. View of the foundation of the 1,500,000 gallon water reservoir (Facility 22020), looking south (ERDC-CERL, 2015). 


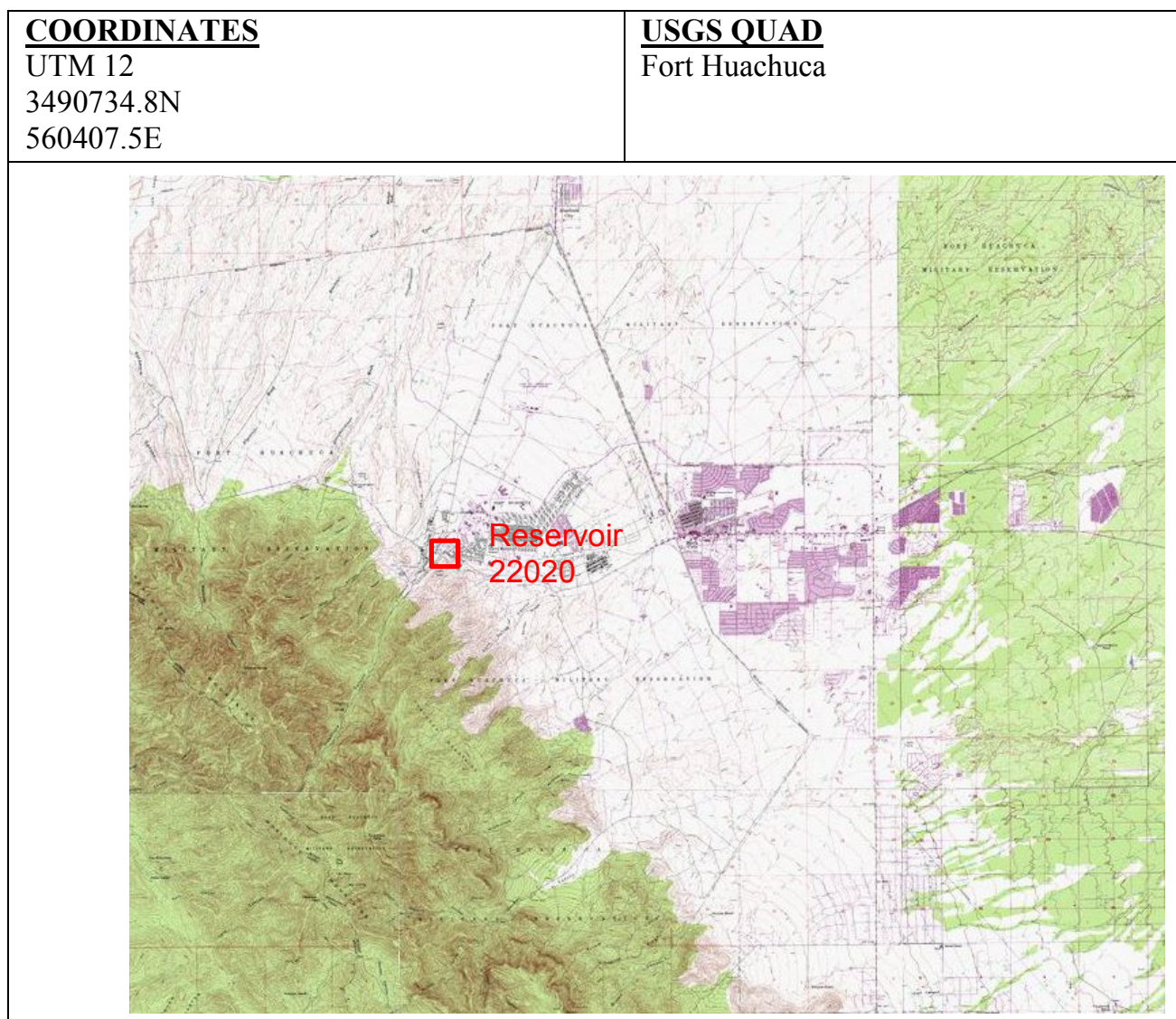

Fort Huachuca, Arizona Quad Map (courtesy USGS). 


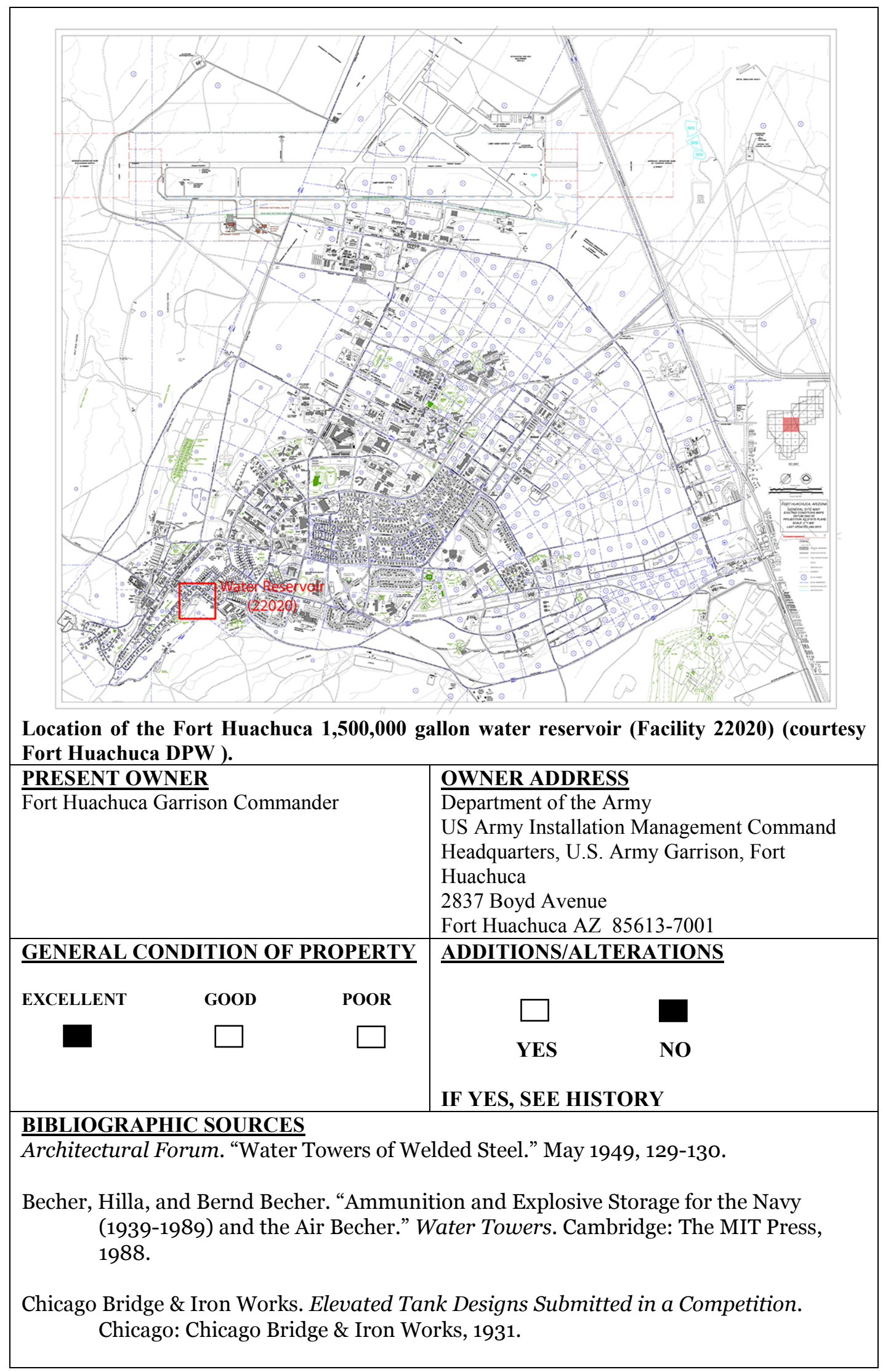


Gray, W. S. Reinforced Concrete Water Towers, Bunkers, Silos, and Gantries. London: Concrete Publications Limited, 1947.

Hazlehurst, J. N. Towers and Tanks for Water-Works. New York: John Wiley \& Sons, 1904.

Headman, Ferguson \& Carollo Architects and Engineers. Completion Report, Cantonment Construction, Fort Huachuca, Arizona. Phoenix, AZ: Headman, Ferguson \& Carollo Architects and Engineers, May 10, 1941. (Accessed at NARA College Park RG77 Construction Completion Reports Fort Huachuca Vol. 4 Box 134).

Herbert, Rand F. 1990. Fort Huachuca, Arizona: A Century of Development and Changing Missions 1877-1977. Davis, CA: Jackson Research Projects.

Loechl, Suzanne K., Susan I. Enscore, Megan Weaver Tooker, and Samuel A. Batzli. Guidelines for Identifying and Evaluating Historic Military Landscapes. Technical Report ERDC/CERL TR-09-6. Champaign, IL: Engineer Research and Development Center, Construction Engineering Research Laboratory (ERDCCERL), 2009.

Spreng, Ronald E. “They Didn’t Just Grow There - Building Water Towers in the Postwar Era.” Minnesota History, Winter 1992.

Tomes, Angel. 2013. Architectural Survey, Documentation, and Evaluation of 110 Buildings and Structures at Fort Huachuca, Arizona. Tucson, AZ: Statistical Research, Inc.

Tomes, Angel, and Scott Thompson. 2014. Inventory, Documentation, and Evaluation of 30 Buildings and Structures, 194 Works Progress Administration (WPA) Features, and Identification of a Potential WPA Historic District at Fort Huachuca, Arizona. Tucson, AZ: Statistical Research, Inc.

Valenzuela, S. Elizabeth. 2011. FY12 SRM Facilities and Demolition Projects: Documentation and National Register Evaluation of 29 Buildings on Fort Huachuca, Arizona. Austin, TX: Valenzuela Preservation Studio.

\section{ARCHIVAL SOURCES}

Records on file at the Fort Huachuca DPW office.

Records on file at the Fort Huachuca Museum Collection.

Records on file at the Fort Huachuca Real Property office.

Records on file at the National Archives at College Park, Maryland.

Records on file at the National Archives at Riverside, California. 


\begin{tabular}{|c|}
\hline $\begin{array}{c}\text { PRELIMINARY NATIONAL REGISTER } \\
\text { DETERMINATION OF ELIGIBILITY }\end{array}$ \\
ELIGIBLE/CONTRIBUTING \\
NON-CONTRIBUTING \\
NOTIGIBLE/
\end{tabular}

PRELIMINARY NATIONAL REGISTER DETERMINATION OF ELIGIBILITY

\section{DESCRIPTION}

Facility 22020 is a $1,500,000$ gallon concrete water reservoir that is overall 30 feet tall and is 92 feet wide; it sits at an elevation of 5,058 feet.

\section{HISTORY}

Facility 22020 is a 1,500,000 gallon concrete water reservoir constructed in 1959.

\section{SIGNIFICANCE}

The 1,500,000 gallon concrete water reservoir while part of the water supply of Fort Huachuca is not significant to the mission of Fort Huachuca, and does not in and of itself have significance at

the national, state or local level under any of the four Criteria.
FORM PREPARED BY:

Courtney Wesa and Adam Smith

Engineer Research and Development Center

Construction Engineering Research Laboratory

2902 Newmark Drive

Champaign, IL 61822
DATE: December 2015 


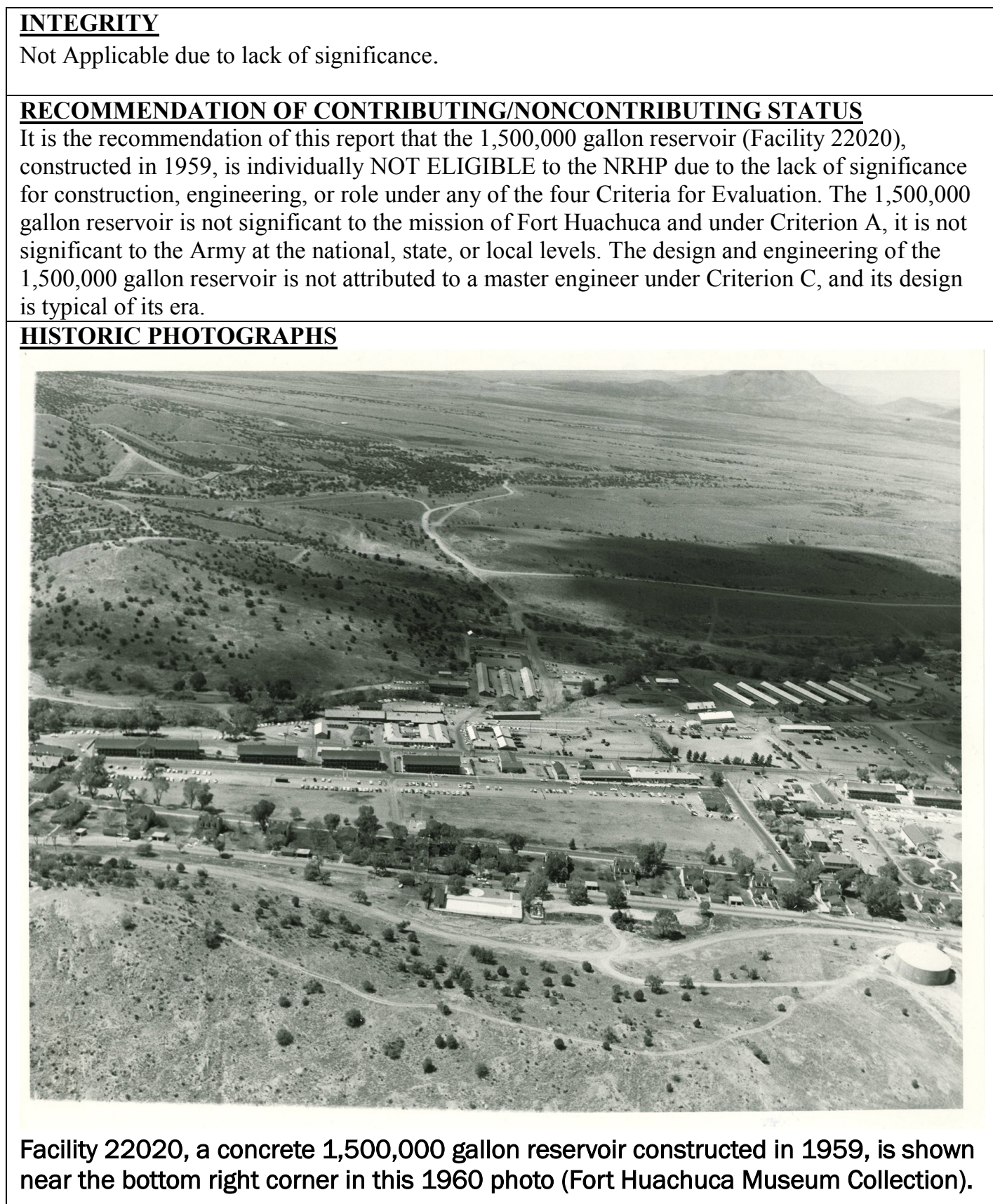




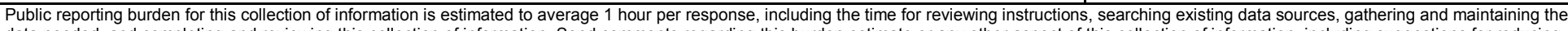

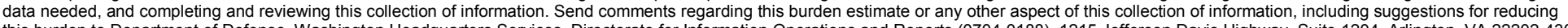

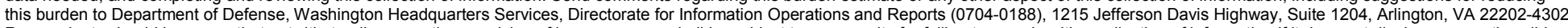

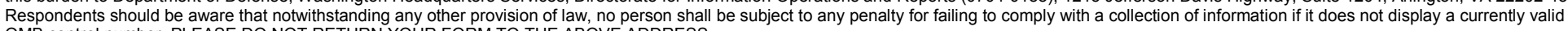
OMB control number. PLEASE DO NOT RETURN YOUR FORM TO THE ABOVE ADDRESS.
1. REPORT DATE (DD-MM-YYYY) August 2016
4. TITLE AND SUBTITLE
NRHP Eligibility of the Fort Huachuca, Arizona, Elevated Water Tank (Facility 49001) and Reservoir (Facility 22020)
2. REPORT TYPE
Final Technical Report

6. AUTHOR(S)

Adam D. Smith and Courtney F. Wesa
3. DATES COVERED (From - To)

5a. CONTRACT NUMBER

5b. GRANT NUMBER

5c. PROGRAM ELEMENT NUMBER

5d. PROJECT NUMBER

447607

5e. TASK NUMBER

5f. WORK UNIT NUMBER

8. PERFORMING ORGANIZATION REPORT NUMBER

ERDC/CERL TR-16-12

7. PERFORMING ORGANIZATION NAME(S) AND ADDRESS(ES)
U.S. Army Engineer Research and Development Center (ERDC)

Construction Engineering Research Laboratory (CERL)

PO Box 9005

Champaign, IL 61826-9005

\section{SPONSORING / MONITORING AGENCY NAME(S) AND ADDRESS(ES)}

10. SPONSOR/MONITOR'S ACRONYM(S)

Environmental and Natural Resources Division

Directorate of Public Works

U.S. Army Garrison

3040 Butler Road, Building 22526

Fort Huachuca, AZ 85613

11. SPONSOR/MONITOR'S REPORT NUMBER(S)

FH-14-17

\section{DISTRIBUTION / AVAILABILITY STATEMENT}

Approved for public release. Distribution is unlimited.

\section{SUPPLEMENTARY NOTES}

\section{ABSTRACT}

This document is an assessment of National Register of Historic Places (NRHP) eligibility of the Fort Huachuca, Arizona, elevated water tank (Facility 49001) erected in 1941 and a reservoir (Facility 22020) constructed in 1959. The elevated water tank (Facility 49001) has remained generally unchanged except for different painting schemes. The demolition and reconstruction of the surrounding World War II temporary buildings makes this portion of the Fort Huachuca cantonment ineligible for the NRHP as a historic district. Although unchanged since its construction, the reservoir (Facility 22020) is not significant for construction technology. This survey satisfies Section 110 of the National Historic Preservation Act of 1966 as amended, and was used to determine the eligibility of the elevated water tank under Section 106 of the NHPA due to an undertaking, and the eligibility of the reservoir under Section 110 of the NHPA for inclusion on the NRHP.

It is the recommendation of this report that the elevated water tank (Facility 49001) is not eligible to the NRHP since it is not individually significant and is not part of a larger historic district. The reservoir (Facility 22020) is individually not significant, and it is not part of a larger historic district.

\section{SUBJECT TERMS}

Fort Huachuca (Ariz.), Historic districts, Military bases, Historic preservation - Evaluation, Architectural surveys, National Register of Historic Places (NRHP), Cultural resources management, Water tower, Water tank, Historic buildings

\begin{tabular}{|c|c|c|c|c|c|}
\hline 16. SECURITY CL & IFICATION OF: & & 17. LIMITATION & 18. NUMBER & 19a. NAME OF RESPONSIBLE PERSON \\
\hline $\begin{array}{l}\text { a. REPORT } \\
\text { Unclassified }\end{array}$ & $\begin{array}{l}\text { b. ABSTRACT } \\
\text { Unclassified }\end{array}$ & $\begin{array}{l}\text { c. THIS PAGE } \\
\text { Unclassified }\end{array}$ & UU & 72 & $\begin{array}{l}\text { 19b. TELEPHONE NUMBER } \\
\text { (include area code) }\end{array}$ \\
\hline
\end{tabular}

